\title{
TAXONOMIC STUDY ON THE GENUS CEPHALOZIA IN RUSSIA AND CIRCUMSCRIPTION OF THE GENUS
}

\section{ТАКСОНОМИЧЕСКОЕ ИССЛЕДОВАНИЕ РОДА СЕРНАLOZIA В РОССИИ И ПОНИМАНИЕ ОБЪЕМА РОДА}

\author{
ALEXEY D. POTEMKIN ${ }^{1} \&$ ELENA V. SOFRONOVA ${ }^{2}$ \\ АЛЕКСЕЙ Д. ПОТЁМКИН ${ }^{1}$, ЕЛЕНА В. СОФРОНОВА ${ }^{2}$
}

Abstract

Polyphyletic origin of the genus Cephalozia shown by recent molecular studies excludes aceptance of traditional concept of the genus and presumes its splitting into Cephalozia s.str. (C. bicuspidata and related species, C. macounii) and Fuscocephaloziopsis (incl. Pleurocladula, Schofieldia, Metahygrobiella), which morphological distinctions are unclear, or circumscription of Cephalozia sensu lato, including all abovementioned genera and Nowellia. Recently established the Jurrasic age of the family Cephaloziaceae s. 1., monophyletic origin of all investigated species of Cephalozia, Fuscocephaloziopsis, Metahygrobiella, Nowellia, Pleurocladula, Schofieldia and common morphology support such a broad circumscription of Cephalozia. Two new nomenclature combinations - C. monticola (J.D. Godfrey) Potemkin \& Sofronova, comb. nov. и C. albula (Steph.) Potemkin \& Sofronova, comb. nov. - are suggested. Seventeen species of Cephalozia sensu lato are recognized for Russia. The key to them, their descriptions, known distribution in Russia, world distribution, ecology, citation of selected illustrations and specimens, description of variability and differentiation as well as original illustrations of principal taxonomic characters are provided for every species. Integrity of Cephalozia sensu lato is confirmed by SEM images of spore surface of $C$. affinis, $C$. albescens, $C$. bicuspidata, $C$. catenulata, C. connivens, $C$. curvifolia, $C$. leucantha, $C$. loitlesbergeri, $C$. macounii, C. monticola and $C$. pleniceps that demonstrate \pm common pattern of outgrowths and are distinct in their density, length, thickness and development of secondary outgrowths.

Резюме

Полифилетичность рода Cephalozia, показанная последними молеклярно-генетическими исследованиями, исключает принятие традиционной концепции рода и предполагает либо его разделение на Cephalozia s.str. (C. bicuspidata и близкие виды, C. macounii) и Fuscocephaloziopsis (включая Pleurocladula, Schofieldia, Metahygrobiella), морфологические различия которых неясны, либо рассмотрение рода Cephalozia в широком смысле, с включением указанных выше родов, а также рода Nowellia. Недавно установленный Юрский возраст семейства Cephaloziaceae sensu lato, монофилетическое происхождение всех исследованных видов Cephalozia, Fuscocephaloziopsis, Metahygrobiella, Nowellia, Pleurocladula, Schofieldia и общность их морфологии поддерживают описание рода Cephalozia sensu lato, с включением всех вышеотмеченных родов. Предложены 2 новые номенклатурные комбинации C. monticola (J.D. Godfrey) Potemkin \& Sofronova, comb. nov. и C. albula (Steph.) Potemkin \& Sofronova, comb. nov. Семнадцать видов рода Cephalozia sensu lato приводятся для России. Ключ для их определения, описания, известное распространение в России и в мире, экология, перечень избранных иллюстраций и изученных образцов, описание изменчивости и отличий, а также иллюстрации важнейших таксономических признаков приведены для каждого вида. Целостность рода Cephalozia sensu lato подтверждается SEM фотографиями поверхности спор C. affinis, C. albescens, C. bicuspidata, C. catenulata, C. connivens, C. curvifolia, C. leucantha, C. loitlesbergeri, C. macounii, C. monticola и C. pleniceps, которые демонстрируют сходный характер выростов оболочки, различающихся по высоте, толщине, густоте расположения и развитию вторичных выростов.

KEYWORDS: Cephalozia, Fuscocephaloziopsis, Metahygrobiella, Nowellia, Pleurocladula, Schofieldia, Cephaloziaceae, Russia, taxonomy, spores, SEM.

1 - V.L. Komarov Botanical Institute Rus. Acad. Sci. 2 Professor Popov Str., St. Petersburg, 197376 Russia; e-mail: Potemkinalexey@mail.ru

2 - Institute of Biological Problems of Cryolitozone of Siberian Division of Rus. Acad. Sci., 41 Lenin Avenue, Yakutsk, 677980 Russia; e-mail: soflena@mail.ru 


\section{INTRODUCTION}

Cephalozia (Dumort.) Dumort. is the type genus of the family Cephaloziaceae Mig. According to recent evaluations Cephalozia includes less than 30 species in traditional circumscription (Váňa, 1988; Váňa, pers. com. 2013). Despite, that the keys to Cephalozia are available there are unsolved taxonomic problems in this genus and difficulties in identification of some species. These facts encourage us to prepare taxonomic treatment of Russian Cephalozia to facilitate their further study in Russia and its adjacent territories. The purpose of present study is to circumscribe the genus Cephalozia and provide approaches for differentiation of its species: keys, descriptions, illustrations and consideration of distinctive characters on the basis of the authors' evaluation of taxonomic features. This resulted in the following structure of the paper: circumscription of Cephalozia and taxonomic treatment of the genus, including complete genus description, evaluation of taxonomic characters and differentiation of the species on the basis of considered characters; the keys to morphological groups of Russian Cephalozia and to species; the descriptions of species with data on their differentiation, selected illustrations, world distribution, known distribution in Russia, ecology, selected specimens examined; excluded taxa.

\section{CIRCUMSCRIPTION OF CEPHALOZIA}

Recent molecular treatments of the family Cephaloziaceae by Vilnet et al. (2012) and Feldberg et al. (2013) demonstrate common origin of Cephalozia, Pleurocladula Grolle, Schofieldia Godfrey, Nowellia Mitt., and Metahygrobiella R.M. Schust. This resulted in definition of the genus Cephalozia as polyphyletic and its splitting into the genera Cephalozia s. str. and Pleurocladula (Vilnet et al., 2012). Accordingly name Pleurocladula was replaced by earlier described Fuscocephaloziopsis Fulford (Váňa et al., 2013). Until present, however, there are some taxa in Cephalozia that have been insufficiently studied to place them in any of the two genera (Váňa et al., 2013). Moreover, morphological criteria for differentiation of Cephalozia s.str. and Fuscocephaloziopsis remain unknown and number of studied species (18 species) appears to be not sufficient for such segregation of the genus Cephalozia if to take into account immense age of the group. Feldberg et al. (2013) recently reported that the Cephaloziaceae sensu lato is a very old group of the Jurassic origin. This presumes extinction of some species, supraspecific taxa and evolutionary scenario of the family. Therefore number of its analyzed species represents just a minute fragment of the whole genus at the scale of its whole history. Similar situation takes place in the other old genera. In the other words: immense age of the group supposes that many of its species and evolutionary scenario are extinct. We deal with a few terminal twigs of the evolutionary tree and due to historical reasons have no possibility to see the whole tree and all its branches (i.e. taxa). As a consequence, we suggest to circumscribe big monophyletic groups as separate genera as it is more justified, than splitting these groups into small "molecular" genera - especially, if these "molecular" genera can not be identified on the basis of morphological characters.

From position of functional morphology such generic aggregation may be explained as follows. Origin of Nowellia resulted from its adaptation for growth on rotten wood in conditions of high humidity of the air. Postical sacs of Nowellia serve for preservation and subsequent assimilation of capillar water from air and substrate. $N$. curvifolia occasionally develops immature leaves without sacs, which resemble much leaves of Cephalozia (Fig. 1) and support their close relationships. Schofieldia and Pleurocladula should have alpine origin associated with nival and/or streamside conditions. Extensive evaporation from antical plant surface and wet postical surface in such conditions had enabled to preserve underleaves, to form concave or canaliculate leaves of these species and develop fleshy stem in Schofieldia. Formation of fleshy stem correlates with reduction of hyalodermis and development of dense rhizoids in Schofieldia. Ecology and morphology of Schofieldia and Pleurocladula recall in leaf shape, branching pattern, shape of underleaves with antipodal alpine and subalpine species previously attributed to Metahygrobiella (Schuster, 2002: Figs. 212-217). This leads us to accept broad circumscription of Cephalozia with inclusion of Fuscocephaloziopsis, Nowellia, Pleurocladula, Schofieldia and Metahygrobiella.

Despite, that the keys to Cephalozia are available, the problems in identification still exist. Such circumscription of the genus Cephalozia segregates it from the other leafy hepatics known from Russia in the following complex of characters: absence of oil bodies; often \pm pellucid appearance and mostly pale green color (except plants of C. ambigua, C. bicuspidata, C. catenulata, C. hamatiloba, C. loitlesbergeri and C. macrostachya from sun lighted habitats); usually \pm distinct (at least on antical side of stem) hyalodermis of larger cells surrounding \pm small-celled medulla (except $C$. monticola and C. pachycaulis); mostly $0.3-0.7$ bilobed leaves with chiefly acute to acuminate or ciliate lobes; smooth cells surface; reduced seta of usually 8 outer and 4 inner cell rows (except C. albescens, C. pachycaulis and C. monticola with occasionally more rows of cells of seta); outer capsule wall with thickenings on alterating longitudinal walls mostly (except C. pachycaulis).

\section{TAXONOMIC TREATMENT}

Complete description of the genus Cephalozia based on personal observations and literature data (Amakawa, 1952a, b; Grolle, 1968; Schuster, 1974; Godfrey, 1976; Paton, 1999; Damsholt, 2002; Schuster, 2002) is provided below.

Cephalozia (Dumort.) Dumort., 1835. Recueil. Observ. Jung.: 18. - Jungermannia L. sect. Cephalozia Dumort., Syll. Jungerm.: 60. 1831. — Nowellia Mitt., 

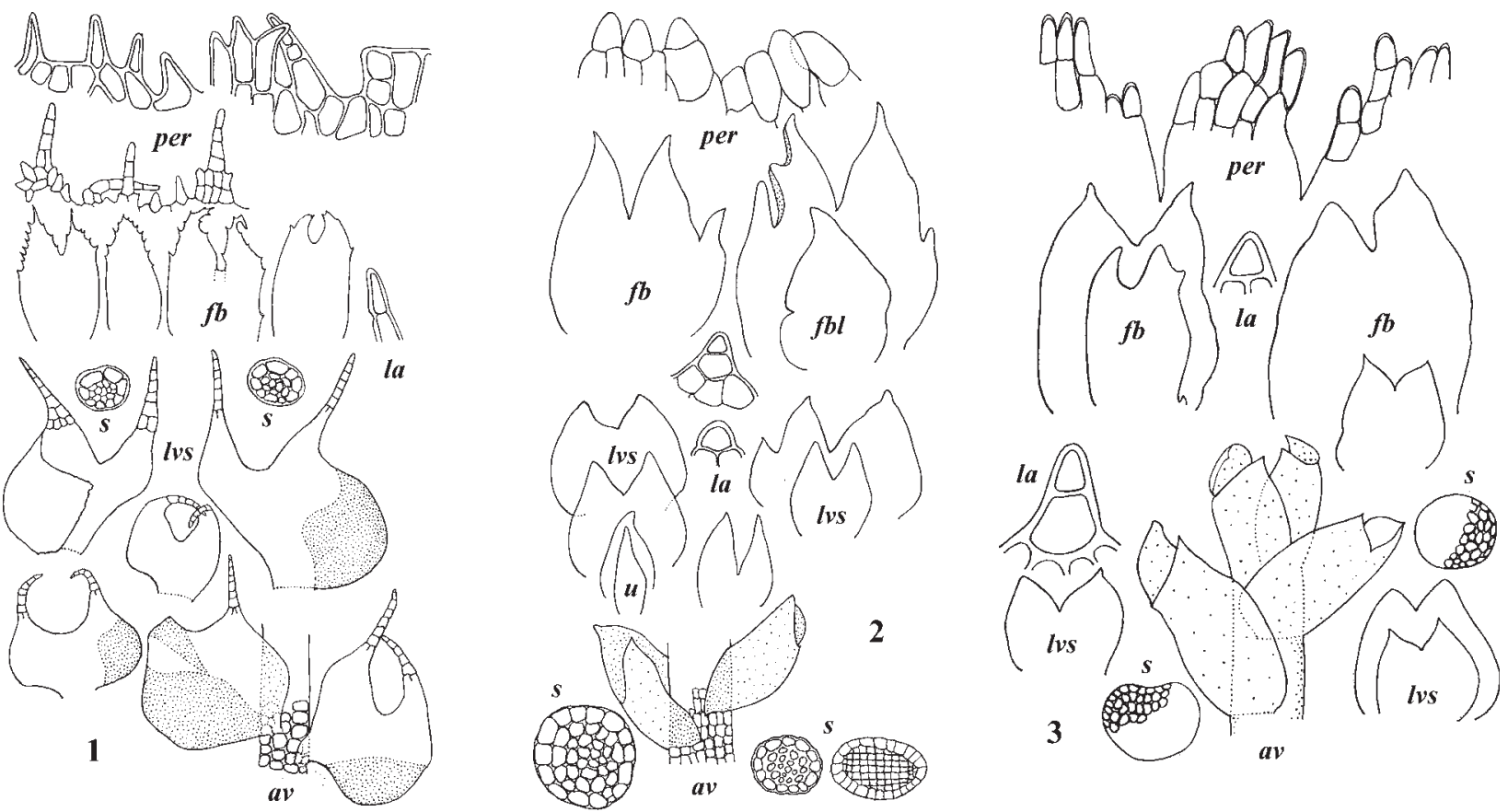

Fig. 1. Taxonomic characters of species without antical-leaf free zone - dioicous, autioicous or paroicous Cephalozia curvifolia (1), dioicous $C$. albescens (2), dioicous $C$. monticola (3): scheme based on original materials from Russia mostly. Abbreviations: $\boldsymbol{a} \boldsymbol{v}$ - antical view (antical leaf-free zone absent), $\boldsymbol{f} \boldsymbol{b}$ - female bract(s), $\boldsymbol{f} \boldsymbol{b}$ - female bractole(s), $\boldsymbol{l} \boldsymbol{v} \boldsymbol{s}$ - leaves, $\boldsymbol{l} \boldsymbol{a}$ - lobe apex, $\boldsymbol{s}$ - stem cross section, $\boldsymbol{p e r}$ - perianth mouth, $\boldsymbol{u}$ - underleaf(ves)

1870. Natural History of the Azores, or Western Islands: 321. - Pleuroclada Spruce, 1882. On Cephalozia: 77, nom. illeg., later homonym - Metahygrobiella R.M. Schust., 1961. Bryologist 64: 205. - Pleurocladula Grolle, 1979. J. Bryol. 10: 269. — Schofieldia J. D. Godfrey, 1976. Bryologist 79: 314. — Fuscocephaloziopsis Fulford, 1968. Mem. New York Bot. Gard. 11(3): 353. Figs. 1-8.

Type: Cephalozia bicuspidata (L.) Dumort. (Lectotype)

Plants whitish green or in some species in open habitats \pm brown and/or intensive purple, creeping, medium-size to minute, shoots (0.15-)0.25-1.5(-1.75) mm wide (in C. monticola $1.5-3 \mathrm{~mm}$ wide) and (1-)3-20(30) $\mathrm{mm}$ long. Stem \pm soft-textured, with larger (particularly on antical side of stem), mostly thin- to somewhat thick-walled cortical cells forming \pm distinct hyalodermis (smaller in C. monticola) and as a rule with small and often \pm thick-walled medullary cells, with or without antical leaf-free zone in sterile shoots and with postical leaf-free zone 2-6 cells wide mostly, about 8-10 cells in $C$. monticola. Branching \pm sporadic, different types characteristic of different species: postical intercalary, lateral intercalary, terminal Frullania-type, stolons characteristic of some species. Rhizoids hyaline, never pigmented, scarce or sometimes rather numerous along postical surface of stem, rhizoid ends usually branched or swollen, in seen materials of $C$. curvifolia neither swollen nor branched. Leaves succubous (subtransverse to hardly incubous in C. curvifolia and related exotic species), horizontal or less often vertical, mostly distant to imbricate and patent to erecto-patent and slightly to strongly antically secund, generally obliquely inserted and often almost longitudinally so; usually bilobed or bifid, occasionaly with small third postical (in C. albescens) or antical (in C. monticola) lobule, regularly with postical lobule in C. curvifolia; plane to \pm concave or \pm canaliculate in C. monticola, C. albula (Steph.) Potemkin \& Sofronova, comb. nov. (basionym: Pleuroclada albula Steph., 1908. Sp. Hepat. 3: 578), C. mollusca (De Not.) Váňa, C. macgregori (Steph.) Váňa and convex in $C$. infuscata R.M. Schust. and C. pulvinata (Steph.) R.M. Schust.; \pm rounded to \pm ovate when mature, often \pm asymmetrical with postical margin usually more strongly arcuate than antical margin; sinus (0.15-)0.25-0.7(-0.8) leaflength, narrowly to broadly rounded or occasionally acute and in C. albescens, C. monticola not rare $\gamma$-like; lobes \pm triangular, acute to acuminate or ciliate, very rare (some phenotypes of $C$. ambigua and C. monticola, singular lobes of $C$. albescens, C. bicuspidata and C. hamatilo$b a$ ) obtuse or \pm rounded; leaf base mostly unistratose, except $C$. monticola with 2-4-stratose leaves near the base. Leaf cells mostly thin-walled, without discrete angular thickenings, in some species with \pm evenly thickened walls at least in lobes. Marginal leaf cells not differentiated in size and wall thickenings. Cell surface smooth or occasionally very finely verruculose on lobe apices. Oil bodies lacking. Underleaves mostly lacking on sterile shoots and on shoots without gemmae (regularly developed on sterile shoots of $C$. albescens, irregularly in C. drucei (R.M. Schust.) Váňa, C. monticola and xeric forms of $C$. pleniceps), present in gynoecia, occasionally in androecia and on gemmiparous shoots. Gem- 
mae in globose clusters at apex of ascending or erect shoots, surrounded by 1-2 circles of concave and often enlarged leaves with edentate or \pm dentate-ciliate margins, pale green, 1(-2)-celled, spherical to ovoid, rarely somewhat angulate, thin- to thick-walled. Gemmiparous shoots may have reduced or \pm malformed leaves occasionally with dentate or ciliate margins as it was mentioned in arctic plants of $C$. albescens and C. bicuspidata (Potemkin, 1993a).

Dioicous or autoicous, very rarely paroicous or synoicous. Androecia spicate on short or very short postical intercalary branches, sometimes on long leafy postical branches or rare on main axes. Male bracts imbricate or contiguous, lobes subequal or unequal in length, straight or incurved; bracteoles usually lacking or rare. Antheridia on 2-seriate stalk, 1 [1(-2) in C. monticola] per bract; jacket of antheridium of several tiers of longitudinally elongate cells (in C. monticola irregularly arranged). Gynoecia on short postical intercalary branches or on longer shoots. Female bracts much larger than sterile leaves, mostly 2- or sometimes 4-lobed and generally with small lateral lobe or tooth on one or both sides, free or slightly connate with bracteole and sometimes also at base of antical margins, bract lobes \pm triangular acute or sometimes blunt to rounded, subulate or linear. Bracteoles mostly present, bilobed, similar to bracts and often as large, lacking in antipodal species earlier attributed to the genus Metahygrobiella R.M. Schust. Perianths poorly to fairly well developed in the absence of fertilization (Paton, 1999), cylindrical or fusiform, \pm trigonal in upper part, with 2 lateral and 1 postical keels, gradually narrowed to crenulate-dentate or lobulate- or laciniate-ciliate mouth, rounded near base; most often chiefly unistratose, except near the base where mostly 13-stratose or 2-4-stratose in C. pachycaulis, 2-8-stratose in $C$. albescens and even 4-5-stratose at most the length and unistratose in the upper half only in some arctic and alpine phenotypes of $C$. pleniceps. Capsules ellipsoidal to cylindrical or \pm obovate or, according to Paton (1999) seldom subspherical, usually 2-stratose (in C. monticola and C. pachycaulis - 2(-3)-stratose). Outer capsule layer of larger slightly elongate cells with \pm distinct nodular thickenings mostly on alternate longitudinal and some latitudinal walls, as an exception (C. pachycaulis) - nearly on all longitudinal and latitudinal walls. Inner capsule layer of smaller narrow cells with \pm distinct nodulose thickenings extending into semiannular bands and located largely on longitudinal walls. Seta usually strongly elongate, of 8 rows of outer cells and 4 rows of inner cells ( $8+4$ type). In C. albescens seta variable from $8+4$ type (seen in Potemkin 92067 02, LE) to 12+8 type (Schuster, 1974: 667), in C. pachycaulis of $8(-9-12)$ rows of outer cells and 5-6(-7) rows of inner cells and sometimes in C. monticola with 9 rows of outer cells and 5 rows of inner cells. Spores (7.5-)8-16(-21) $\mu \mathrm{m}$, look finely papillose or vermiculose in most species or finely reticulate in C. lunulifolia (light microscope LM data). According to scanning electron microscope (SEM) data (Figs. 5-7) spore surface in Cephalozia consists of \pm dense outgrowths with \pm roughly verruculose surface. Most outgrowths are often terminated by short secondary spherical outgrowths that were not seen in $C$. catenulata, C. curvifolia and C. leucantha. The outgrowth bases may form \pm vermiculate areolation on spore surface. In $C$. lunulifolia they are \pm remote and regularly confluent and form reticulate areolation. In the other species the reticulate areolation is hardly developed. Elaters 2- or in $C$. albescens occasionally partly 3-spiral. Spore/elater diameter ratio varies much within the genus. Spore/elater diameter ratio varies much within the genus (See description of Spores, page 000).

\section{EVALUATION OF TAXONOMIC CHARACTERS}

Delineated above taxonomic characters of Cephaloz$i a$ are rather flexible and always need to be analyzed together. Their variation pattern is often unclear. The following characters are of principal importance: leaf shape and insertion, antical leaf-free zone evidence, absence or presence of underleaves and of secondary pigmentation (in sun lighted habitats), branching pattern, cell size, degree of hyalodermis development, pattern of antical leaf base insertion, leaf and stem cell wall thickenings, apical cell wall thickening, shape of rhizoid ends, sex distribution, shape of bracts, perianth mouth structure, spore size and surface; spore/elater diameter ratio. These characters provide basis for differentiation of Russian Cephalozia. Most of them were used in various extents in previous treatments of the genus. In this treatment we were focused on leaf shape analysis (see description of shape of leaves below), antical leaf-free zone evidence and apical cell wall thickness. Two latter characters were used by Paton (1999) and they work well for identification of Russian Cephalozia species. Most of mentioned above characters are delineated in the genus description and the species comments below. Some of them need to be considered separately to help species identification.

\section{"Macroscopic" characters}

These characters are used for primary investigation of specimens with handlens and/or stereomicroscope.

\section{Secondary pigmentation}

Most species of Cephalozia never develop secondary pigmentation and are always green or whitish green. Brown and/or purple pigmentation is characteristic of species of $C$. bicuspidata complex from sun lighted habitats (C. ambigua, C. bicuspidata, C. hamatiloba) and C. curvifolia. C. catenulata, C. macrostachya and C. loitlesbergeri often develops brown pigmentation in different extent.

\section{Antical leaf-free zone}

This is useful character for primary differentiation of larger plants of Cephalozia. In C. bicuspidata complex, C. albescens, C. curvifolia, C. macounii, C. monticola antical leaf bases are inserted to neighbour antical cell 
rows of the stem and antical leaf-free zone is not distinguished in plants with subtransverse leaves. This distinction, however, becomes doubtful when juvenile plants of C. bicuspidata and C. hamatiloba with nearly longitudinally inserted leaves are in hand. In such cases, antical leaf-free zone looks two cells wide and only careful observation shows that antical leaf bases are inserted to outmost margins of neighbour antical cell rows of the stem (Fig. 2). For the other species antical leaf-free zone was described as 2 cells wide (Paton, 1999). In fact, it is more variable and sometimes may be 1 or 3 cells broad. Its exact width may be defined in the course of careful microscopic study only. Such a variability of antical leaffree zone is characteristic of C. pachycaulis and C. pleniceps. If in mature sterile shoots of Cephalozia antical leaf-free zone varies from 1 to 3 cells broad, in androecia on main shoots it is absolutely indistinct.

- Antical end of leaf insertion line extending on to median cortical cells: C. albescens, C. ambigua, C. bicuspidata, C. curvifolia, C. hamatiloba, C. macounii, C. monticola.

- Antical leaf-free zone on sterile shoots \pm distinct, (12(-3) cells wide: $C$. affinis, C. catenulata, C. connivens, C. lacinulata, C. leucantha, C. loitlesbergeri, C. lunulifolia, C. macrostachya, C. pleniceps, C. pachycaulis.

\section{Leaf insertion}

Definition of leaf insertion pattern demands identification of antical and postical leaf base insertion. It correlates with leaf density being usually oblique to nearly longitudinal in plants of mod. laxifolia and oblique to subtransverse in plants of mod. densifolia. The following key provides an approach to differentiate Russian Cephalozia species on the basis of leaf insertion.

1. Transverse or hardly incubous, not decurrent......... C. curvifolia (Fig. 1).

- Succubous 2

2. Line of insertion slightly curved: longitudinal or oblique insertion 3

- Line of insertion distinctly or strongly curved ...... 4

3. Longitudinal insertion

C. lunulifolia p. p., C. connivens, C. loitlesbergeri, C. lacinulata, mod. parvifolia-angustifolia-laxifolia of C. bicuspidata and C. hamatiloba, C. catenulata p. p., C. pleniceps p. p., C. leucantha p. min. p. (Fig. 3: C. connivens, C. lacinulata, C. loitlesbergeri).

- Oblique insertion.C. pleniceps p. p., C. lunulifolia p. p., mod. laxifolia of C. ambigua, C. bicuspidata and C. hamatiloba, C. catenulata p. p., C. lacinulata p .p. (Fig. 3: C. catenulata, C. macrostachya).

4. Subtransverse not decurrent insertion on antical side and \pm oblique on postical side of stem most phenotypes of C. ambigua, C. bicuspidata, $C$. hamatiloba and C. albescens, C. leucantha p. max. p., C. pachycaulis, C. macounii (Fig. 1: C. albescens, Fig. 2, Fig. 3: C. leucantha).

- Transverse insertion of antical part of leaf and ob- lique of postical part of leaf (leaves canaliculate to conduplicate) C. monticola (Fig. 1).

\section{Leaf shape}

There are several important characters of leaf shape in Cephalozia: absence or presence of ventral sac, length of insertion [very short, ca. 3-5 times shorter than leaf width vs. similar or shorter, (0.85-)1-1.5(-2) leaf width], leaf length/width ratio [subequal $0.8-1.1(-1.3)$ : 1 vs. considerably longer than wide (1.2-)1.5-2: 1], longitudinal symmetry of leaves (symmetrical vs. asymmetrical), curvature of outer margins, shape of lobes (acute, acuminate, ciliate, blunt, rounded), orientation of lobes (straight, connivent, contiguous to cruciate), depth of sinus (0.15$0.3 ; 0.3-0.5 ; 0.5-0.8)$ and shape of sinus (U-, V- or $\gamma-$ like), antical decurrency (absence or presence).

1. Leaves with postical sac, strongly constricted at base, line of insertion ca. 3-5 times shorter than leaf width, lobes ciliate C. curvifolia (Fig. 1)

- Leaves without postical sac, not constricted at base, line of insertion ca. (0.85-)1-1.5(-2) leaf width .. 2

2. Leaves nearly symmetrical (postical and antical leaf bases convex to straight in the lower half) ......... 3

- Leaves asymmetrical (postical leaf base convex and antical leaf base concave in the lower half) ........ 9

3. Leaves plane to concave; sinus (0.3-)0.35-0.8 leaf length 4

- Leaves canaliculate; sinus shallow, (0.15-)0.2-0.4 leaf length C. monticola (Fig. 1)

4. Leaves considerably longer than wide [(1.2-)1.5-2: 1], with deep sinus ca. $0.55-0.8$ the leaf length ... 5

- Leaves broader, ca. 0.8-1.1(-1.3): 1 as long as wide, with mostly shallower sinus

5. Leaves of distinctly to slightly thick-walled small cells, 12-19 $\mu \mathrm{m}$ wide at base of lobes, with often uneven subdentate margins at places of transverse cell walls; secondary pigmentation lacking ............ C. macounii (Fig. 2)

- Leaves of thin-walled and larger cells, with entire margins mod. parvifolia angustifolia of C. bicuspidata, C. hamatiloba (Fig. 2)

6. Leaves broader than stem, often dense and conceal stem, their postical part often \pm larger than antical

- Leaves about as wide as stem usually small and distant, not conceal stem, their postical part often smaller than antical C. leucantha (Fig. 3)

7. Leaves not constricted at base from both sides ....... C. affinis, C. catenulata p. max. p., C. lacinulata, C. lunulifolia, C. macrostachya, C. pleniceps

- Leaves constricted at base from both side ............ 8

8. Sinus mostly V-like or U-like, not narrowed to the base .... C. ambigua, C. bicuspidata, C. hamatiloba

- Sinus sporadically \pm narrowed to the base V-like or $\gamma$-like C. albescens (Fig. 1) 

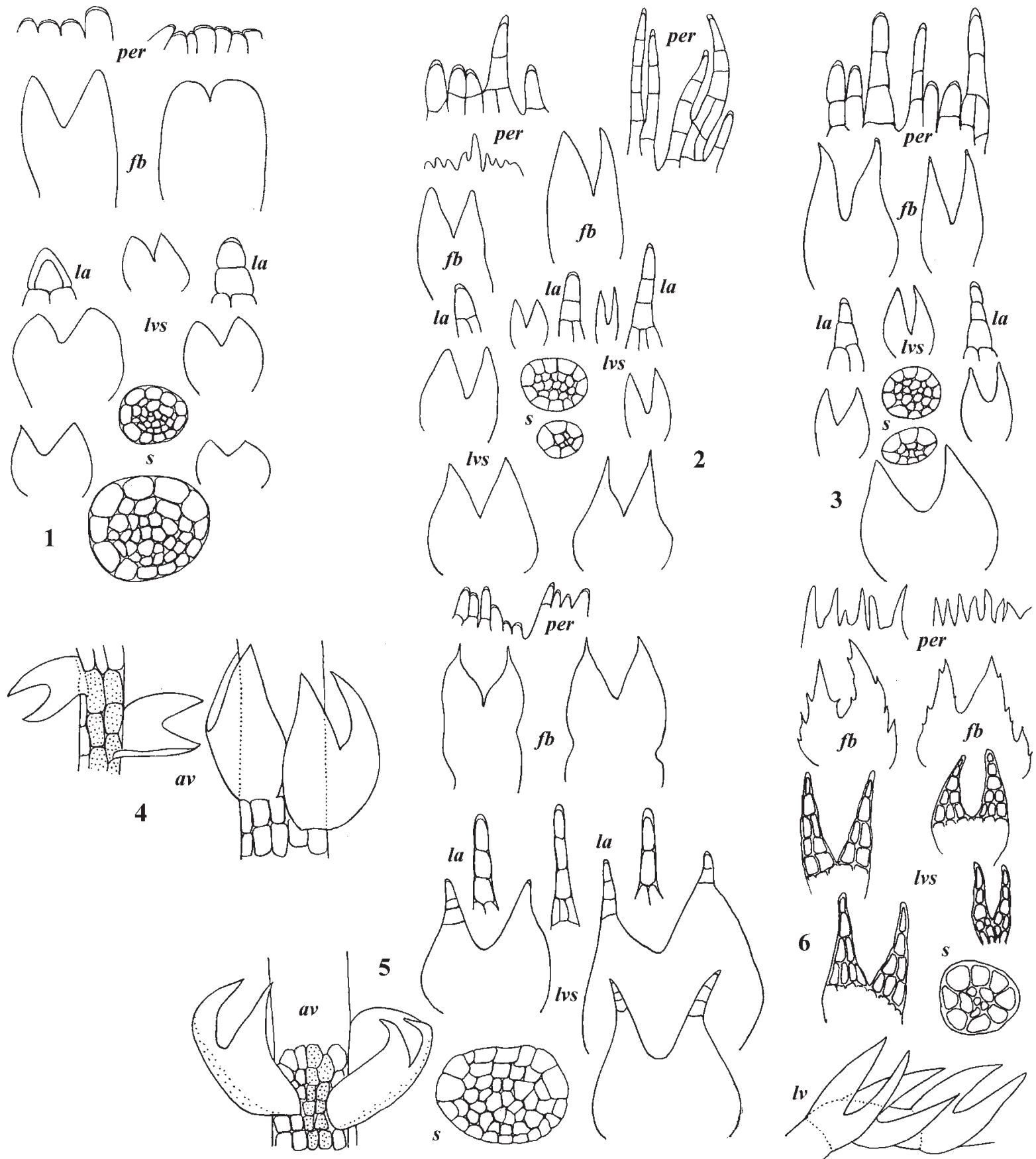

Fig. 2. Taxonomic characters of species with transversely inserted antical leaf base: autoicous Cephalozia ambigua (1), C. bicuspidata (2), C. pachycaulis (5) and dioicous C. hamatiloba (3), C. macounii (6), 4 -antical leaf insertion of species 1-3 - antical leaf-free zone absent, at 5 - antical leaf-free zone distinct: scheme based on original materials from Russia mostly. Abbreviations: $\boldsymbol{a v}$ - antical view, $\boldsymbol{f} \boldsymbol{b}$ - female bract, $\boldsymbol{l} \boldsymbol{v}$ - lateral view, $\boldsymbol{l} \boldsymbol{v} \boldsymbol{s}$ - leaves, $\boldsymbol{l a}$ - lobe apex, $\boldsymbol{s}$ - stem cross section, per - perianth mouth.

9. Leaves with 2-3-celled sometimes contiguous to cruciate uniseriate ends C. loitlesbergeri (Fig. 3)

- Leaves with 1-2-celled uniseriate ends 10

10. Cells small to medium size, $20-33 \times 25-40 \mu \mathrm{m}$ at base of lobes. Lobes mostly not connivent
C.
C. lunulifolia
(Fig. 4)

- Cells large, $(25-) 28-50(-65) \times(30-) 37-70(-80) \mu \mathrm{m}$ at base of lobes. Lobes often connivent

C. connivens (Fig. 3)

\section{Shape of lobe apices}

Most studied species of Cephalozia have acute to acuminate lobe apices. C. curvifolia has ciliate ends of lobes. $C$. ambigua and $C$. monticola have occasionally broadly rounded lobe apices whereas $C$. albescens, $C$. bicuspidata, C. hamatiloba and C. leucantha rare develop blunt or narrowly rounded lobe apices of separate leaves. Acuminate to ciliate lobe apices are characteristic of C. loitlesbergeri, C. pachycaulis and of some phenotypes of $C$. bicuspidata. 


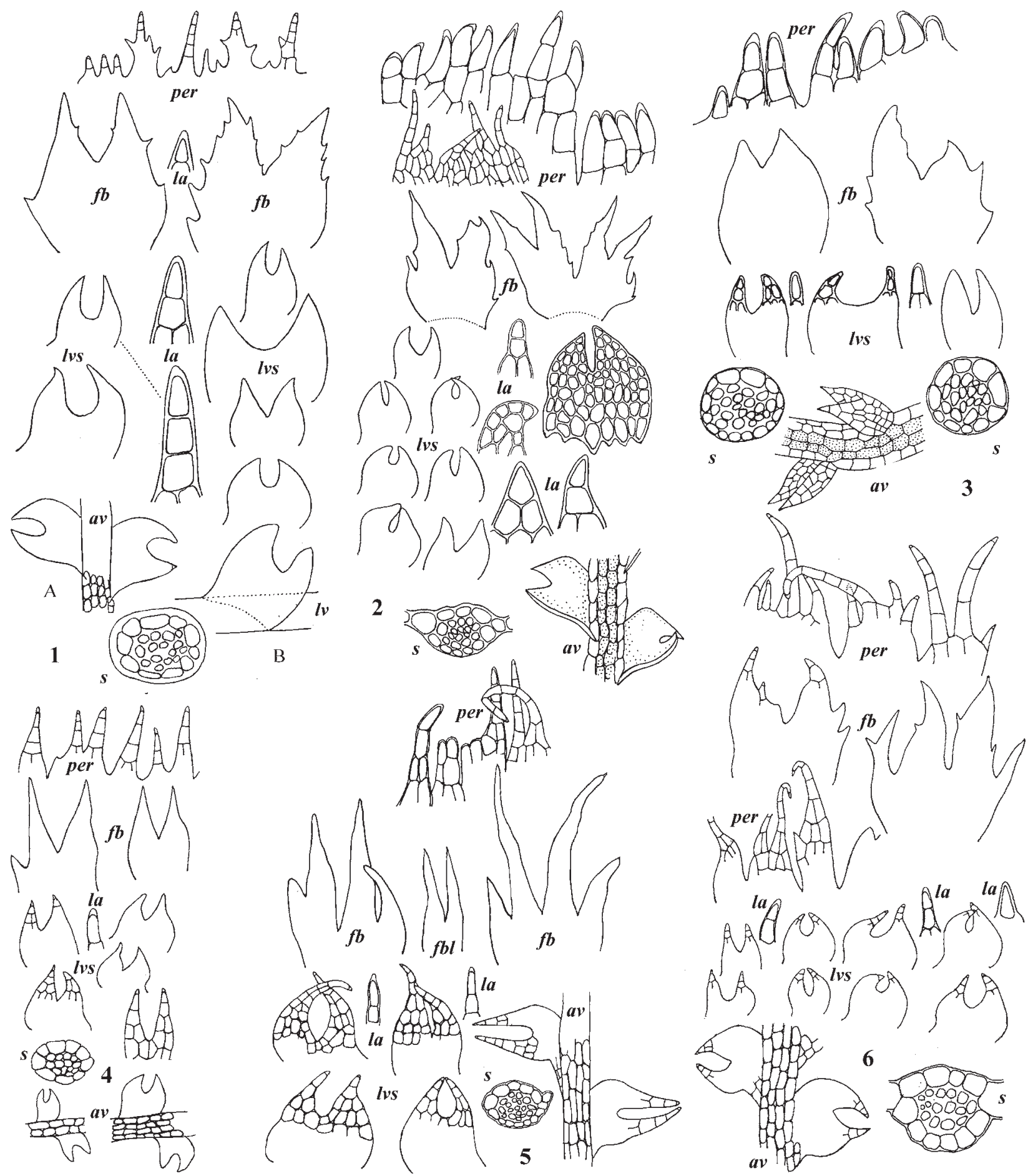

Fig. 3. Taxonomic characters of Cephalozia species with distinct antical leaf-free zone: dioicous - C. catenulata (1, A - leaf inserion of subsp. nipponica, B - of subsp. catenulata), C. macrostachya (2), C. leucantha (3), C. lacinulata (4), autoicous - C. loitlesbergeri (5), C. connivens (6): scheme based on original materials from Russia mostly. Abbreviations: $\boldsymbol{a} \boldsymbol{v}-$ antical view, $\boldsymbol{f b}-$ female bract, $\boldsymbol{f} \boldsymbol{b} \boldsymbol{l}$ - female bractole, $\boldsymbol{l} \boldsymbol{v}$ - lateral view, $\boldsymbol{l} \boldsymbol{v} \boldsymbol{s}$ - leaves, $\boldsymbol{l} \boldsymbol{a}$ - lobe apex, $\boldsymbol{s}$ - stem cross section, per - perianth mouth.

\section{Leaf density}

In most species of Russian Cephalozia leaf density varies from subimbricate to distant or remote. It often correlates with leaf insertion. Subimbricate leaves are often subtransversely inserted at least antically. Remote leaves are mostly longitudinally inserted. In C. leucantha, however, remote leaves are usually subtransversely inserted.

\section{Underleaves on sterile shoots}

Underleaves usually lacking on sterile nongemmiparous shoots of most Cephalozia species. They constantly present, large and easily distinguished in C. albescens only. In $C$. monticola they are variable in size, not patent and often distinguished with difficulty because of dense rhizoids. As an exception C. bicuspidata and C. hamati- 

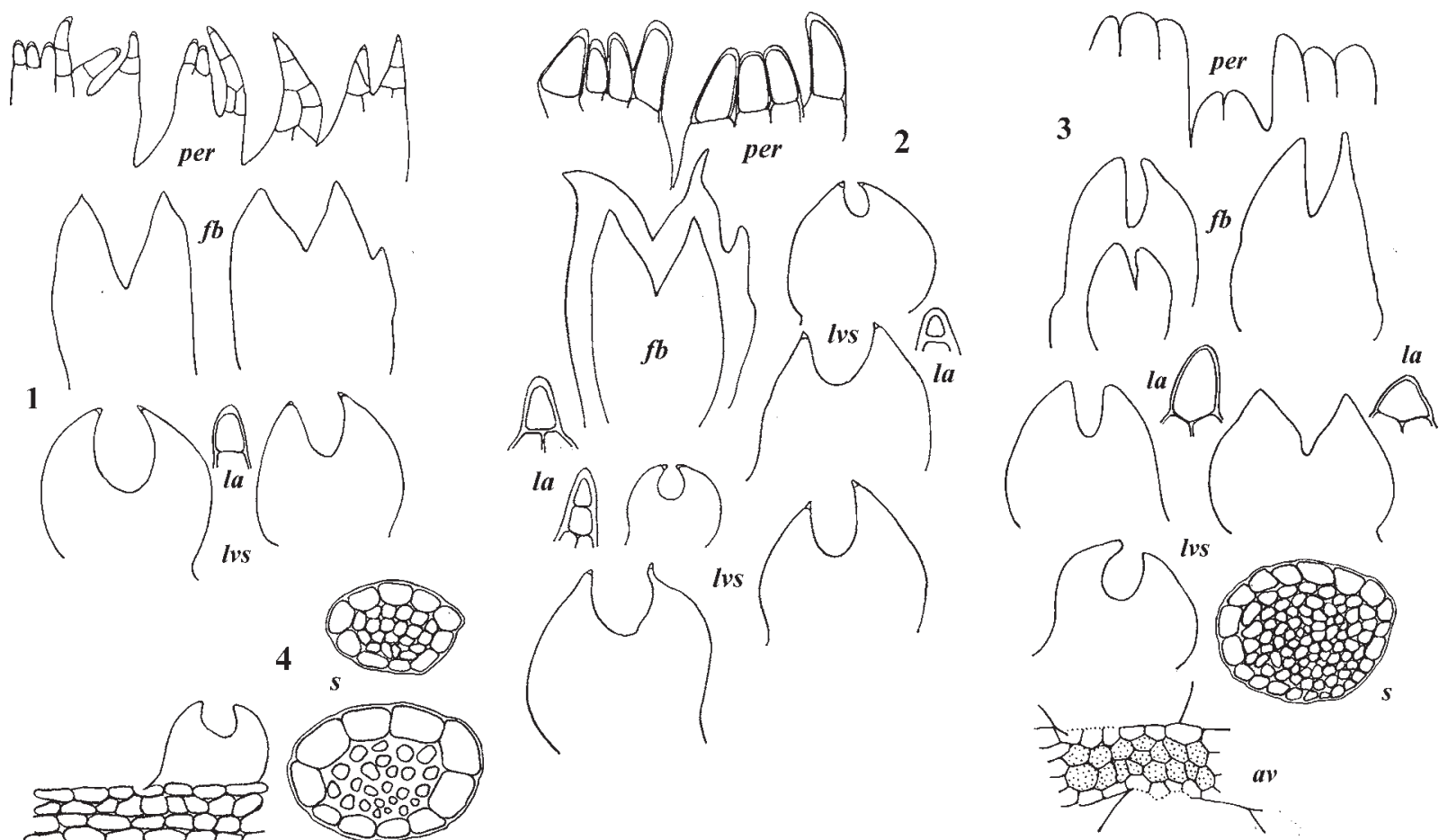

Fig. 4. Taxonomic characters of Cephalozia species with distinct antical leaf-free zone: autoicous C. affinis (1), C. pleniceps (3), dioicous - C. lunulifolia, 4 - leaf insertion and stem cross sections for 1, 2: scheme based on original materials from Russia mostly. Abbreviations: $\boldsymbol{a} \boldsymbol{v}$ - antical view, $\boldsymbol{f} \boldsymbol{b}$ - female bract, $\boldsymbol{l v \boldsymbol { s }}$ - leaves, $\boldsymbol{l} \boldsymbol{a}$ - lobe apex, $\boldsymbol{s}$ - stem cross section, per - perianth mouth.

loba may develop large C. albescens-like underleaves. This was observed in plants of $C$. cf. hamatiloba growing in Valley of Geysers (Uzon Caldera) in Kamchatka and in C. bicuspidata in the Yamal Peninsula. Such plants resemble $C$. albescens in shape and size of underleaves but differ from the latter in presence of secondary pigmentation first of all.

\section{Branching}

Postical intercalary: characteristic of all species, rare in $C$. albescens.

Stolons: C. ambigua, C. bicuspidata, C. hamatiloba,

C. loitlesbergeri, C. pleniceps.

Terminal Frullania-type: C. albescens, C. ambigua,

C. bicuspidata, C. hamatiloba, C. monticola, C. pachycaulis, C. pleniceps.

Lateral intercalary: C. albescens, rare in C. curvifolia.

\section{Stem thickness}

Arctic plants of $C$. pleniceps often develop remarkably thick and fleshy stems. Their formation is characteristic of plants with dense and fleshy leaves. Fleshy stems are characteristic of $C$. leucantha, C. monticola and $C$. pachycaulis also. The stems in the former species look thick and fleshy because of remote and often scale-like leaves about as wide as stem. Plants of $C$. leucantha are mostly distinct due to such stems with comparatively unremarkable leaves. As an exception, thick and fleshy stems occur in xylicolous plants of $C$. lunulifolia from rather xeric habitats. Remarkably thin stems, like in Cephaloziella species, (35-)45-60(-85) $\mu \mathrm{m}$ are in Cephalozia macounii.

\section{Bracts shape}

Bracts usually bilobed, in some species with additional lateral teeth, entire or variously dentate (Figs. 14). Most species in question develop entire bracts. $C$. curvifolia have mostly densely serrate to finely denticulate bracts in the upper half. Formation of \pm dentate bracts is characteristic of C. catenulata, C. macounii, C. macrostachya, some phenotypes of $C$. leucantha (Paton, 1999: Fig. 36), C. bicuspidata var. lammersiana f. serratifolia (Damsholt, 2002: P1. 184: 1, 5.) and C. hamatiloba phenotype known as $C$. otaruensis var. setiloba (Amakawa, 1952: Fig. 5: H). Dentate or serrate bracts may be distinct in young gynoecia with not developed perianths. All abovementioned species demonstrate a broad variability in bract dentition: from dentate to subentire.

Entire bracts differ in shape of lobes and depth of sinus. In most species with entire bracts bract lobes \pm triangular acute or sometimes blunt to rounded and sinus shallow to 0.6 their length (Figs. 1-4), in C. loitlesbergeri sinus mostly deeper and lobes nearly linear (Fig. 1).

\section{Perianth mouth}

In the course of hand-lens investigation of fresh collected specimens it is possible to differentiate plants with \pm ciliate-laciniate perianths. Such perianths are characteristic of $C$. connivens, $C$. loitlesbergeri, $C$. lacinulata, C. catenulata, some forms of C. macrostachya, C. bicuspidata and C. hamatiloba (Figs. 2, 3). The other species have lobulate dentate to crenulate and subentire perianth mouth (Figs. 1-4). Sometimes cilia of ciliate peri- 
anth mouth may be broken or destroyed by fungi like it was observed in $C$. connivens.

\section{"Microscopic" characters}

Microscopic characters are important for confirmation of identification made on the basis of "macroscopic" characters, which possible to study with stereomicroscope or even hand-lens.

\section{Cells}

Cell size and cell wall thickness are very important for correct identification of Cephalozia species. However, they are variable and depend much on conditions in which plants grow. Small cells usually have narrower variability ranges than larger ones.

\section{Leaf cells}

- Smallest, distinctly to slightly thick-walled and less variable in size, ca. 10-20(-24) $\mu \mathrm{m}$ wide at base of lobes, somewhat broader in C. curvifolia ca. (15-)2025(-28) $\mu \mathrm{m}$... C. ambigua, C. catenulata, C. curvifolia, C. leucantha, C. macounii, C. macrostachya - Larger ca. (20-)24-35(-40) $\mu \mathrm{m}$ wide at base of lobes, thin- to slightly thick-walled

C affinis, C. albescens, C. bicuspidata, C. hamatiloba, C. loitlesbergeri, C. lunulifolia, C. monticola

- Large and variable in size sometimes even on one shoot, (20-)25-50(-65) $\mu \mathrm{m}$ at base of lobes, thin- to thick-walled ....

C. connivens, C. pachycaulis, C. pleniceps Antical cortical cells

Antical cortical cells mostly longer than wide and \pm longitudinally elongate, stronger elongate in plants of mod. laxifolia and slighter elongate to subisodiametric in plants of mod. densifolia. They usually about $\times 1-1.5$ times broader and $\times 1-2$ times longer than cells at the bases of lobes. However, in most common mod. densifolia of C. curvifolia they are very regularly arranged, subquadrate or a little latitudinally elongate and often a little broader than long, considerably larger than cells at base of lobes, (25-)40-50(-55) $\times 25-50(-75) \mu \mathrm{m}$ vs. (1520-25(-28) $\times 20-30(-35) \mu \mathrm{m}$ respectively; in C. leucantha and C. monticola antical cortical cells often 1.5-2 times broader than cells at the lobe bases (16-)20-28($34)$ vs. $10-20 \mu \mathrm{m}$ and (27-)35-75 vs. (20-)25-35(-40) $\mu \mathrm{m}$ respectively whereas in $C$. lacinulata they are often somewhat narrower and longer $25-35 \times 60-80 \mu \mathrm{m}$ vs. 20 45×25-50 $\mathrm{mm}$.

\section{Leaf cell walls}

Most species of Cephalozia have thin-walled cells and rare develop slightly to moderately evenly thickened walls. Discrete trigones are lacking in leaf cells. In $C$. catenulata, C. leucantha, C. macounii, C. macrostachya cells have moderately to rather strongly \pm evenly thickened walls.

Thickening of apical wall of terminal cells of lobes (Figs. 1-4) is mostly strongly developed in C. macounii, C. lacinulata, C. lunulifolia, variably and often slightly - in C. bicuspidata complex, C. affinis, C. curvifolia, $C$. catenulata, C. connivens, C. macrostachya, C. pachycaulis and lacking in $C$. albescens, $C$. monticola and $C$. pleniceps. Thickenings of apical wall of terminal cells of lobes is an important character to differentiate C. pleniceps, having no apical wall thickenings, from $C$. lunulifolia, which usually develop distinct apical wall thickenings. However, phenotypes of C. lunulifolia from some xylicolous habitats (e.g. Potemkin 12.06.1990, LE) have evenly thickened cell walls of leaves and are unable to develop extra thickenings of apical wall of the terminal cells. Similar tendency was mentioned for C. leucantha. This character is rather flexible in C. ambigua, $C$. bicuspidata and $C$. hamatiloba. In these species apical thickenings usually lacking in plants growing on soil and present in xylicolous plants which grow in intermittent humidity conditions. Intermittent humidity may cause stronger development of such thickenings in the other species of the genus also.

\section{Hyalodermis and medulla}

Hyalodermis is characteristic of most species of Cephalozia except $C$. monticola, $C$. pachycaulis and some phenotypes of $C$. pleniceps. Reduction of hyalodermis in Cephalozia correlates with formation of thick fleshy stems. In thicker stems of the same species hyalodermis is usually stronger developed than in thinner stems. In C. monticola stem very fleshy and outer cells smaller than medullary cells (Fig. 1). In C. pachycaulis hyalodermis is not distinct on main shoot but might be distinct at the base of thinner postical intercalary branches, in C. pleniceps it may be gradually transformed into not or slightly thickened medullary cells.

Degree of differentiation of the hyalodermis might be evaluated through antical outer/adjacent medullary cell width ratio, which is usually $\leq 2$ : 1 in $C$. ambigua, $C$. albescens, C. bicuspidata, C. leucantha, C. macounii, C. pachycaulis, C. pleniceps and $>2: 1$ in C. affinis, C. catenulata, C. connivens, C. curvifolia p. p., C. macrostachya. The other species may fall into both groups.

\section{Medullary cell thickenings}

- Medullary cells thin- to moderately evenly thickwalled like outer cells ............... C. albescens p. p., C. ambigua, C. bicuspidata, C. hamatiloba, C. monticola, C. pachycaulis, C. pleniceps p.max.p.

- Medullary cells similarly or mostly slighter thickened than outer cells ........................... c. curvifolia

- Medullary cells considerably stronger thickened than outer cell .

C.affinis, C. albescens p.min.p., C. connivens, $C$. catenulata, C. lacinulata, C. leucantha, C. loitlesbergeri, C. lunulifolia, C. macounii, C. macrostachya, $C$. pleniceps p.min.p.

Damsholt (2002) mentioned and illustrated pitted cell walls of medullary cells of $C$. catenulata, $C$. connivens, C. lacinulata, C. leucantha, C. loitlesbergeri, C. macrostachya. This at first glance convenient character is difficult for investigation and comparison be- 
cause demands evenly thin stem cross sections of all studied species.

\section{Rhizoid ends}

- Swollen or indistinctly or hardly branched ............. C. ambigua, C. albescens, C. bicuspidata, C. catenulata, C. connivens, C. hamatiloba p. max. p., C. loitlesbergeri, C. macounii, C. monticola, C. macrostachya p. p. C. pleniceps.

- Distinctly branched C. affinis, C. lacinulata, C. leucantha, C. lunulifolia, C. macrostachya p. p., C. pachycaulis.

- Neither swollen nor branched C. curvifolia. Spores

Spores in studied materials of Cephalozia differ in absolute and comparative size (spore/elater ratio), areolation, presence and degree of development of secondary outgrowths, i. e. punctation of spores (Figs. 5, 6). Their distinctions in these characters may be classified as follows.

Spore size:

- Minute, about 8-12 mm.... C. affinis, C. ambigua p.p., C. catenulata, C. curvifolia, C. lacinulata p.p., $C$. leucantha, C. loitlesbergeri, C. lunulifolia, C. macounii, C. macrostachya p.p., C. pachycaulis

- Medium-size, about 12-15 $\mu \mathrm{m}$.. - C. albescens, $C$. ambigua p.p., C. bicuspidata, C. lacinulata p.p., $C$. macrostachya p.p., C. monticola, C. pleniceps p.p.

- Large, 15-21 $\mu \mathrm{m}$.......................... C. pleniceps p.p. Spore/elater diameter ratio

- Variable, 1-2: 1 - C. albescens, C. monticola

— About 1: 2 ........................................... C. pleniceps

- About 1.5: 1 ............... C. ambigua, C. affinis, C. bicuspidata, C. catenulata, C. macounii, C. pachycaulis

- As wide or a little wider than elaters

C. connivens, C. curvifolia, C. hamatiloba, C. lacinulata, C. leucantha, C. loitlesbergeri, C. macrostachya Spore surface (SEM only)

- Distinctly reticulate-punctate (Fig. 5: 2) C. lunulifolia

- Densely thickly reticulate- or vermiculate punctate (Figs. 5: 1, 3, 4, 6: 1-4)

C. affinis, C. bicuspidata, C. connivens, $C$. macounii, $C$. loitlesbergeri, $C$. pleniceps

— Echinate and \pm punctate (Figs. 5: 5-6, 6: 5-6) ...... C. albescens, C. monticola

- Vermiculate, mostly not punctate (Fig. 7). C. catenulata, C. curvifolia, $C$. leucantha

MORPHOLOGICAL GROUPS OF RUSSIAN CEPHALOZIA

Descriptions of Cephalozia species below are arranged in tentative morphological groups because of still unsolved problems of infrageneric systematics of the genus. Some earlier recognized taxonomic groups are clearly defined even when sterile: Nowellia $-C$. curvifolia, Schofieldia - C. monticola and Pleurocladula - C. albescens correspond former genera Nowellia, Schofieldia, Pleurocladula. Morphology of the groups Pachycaules
- C. pachycaulis, Pleniceps - C. pleniceps, Macouniae - C. macounii and Leucanthae - C. leucantha is rather specific to differentiate them. The other group of species is Cephalozia: C. ambigua, C. bicuspidata, C. hamatiloba corresponds to section Cephalozia. C. affinis, C. lunulifolia of section Lunulifoliae, C. connivens, C. lacinulata, C. loitlesbergeri - of section Lacinulatae, and $C$. catenulata, C. macrostachya of section Catenulatae are treated here together as group Obscurae because of considerable variability of sterile plants of these sections that solve their sharp distinctions at section level. It is noteworthy that groups Nowellia, Schofieldia, Pleurocladula, Cephalozia and Pleniceps share \pm regular presence of terminal branches lacking in the other groups of Cephalozia. In species descriptions below set of morphological characters was selected specifically for identification of species of every group.

\section{Comments to the key and species descriptions}

Exact measurements of plant size are omitted in descriptions (except minute plants) because of considerable variability of Cephalozia species. The following scale of measurements is provided: minute - ca. $0.1-0.3 \mathrm{~mm}$ wide, small - ca. 0.3-0.6 mm wide, medium-size ca.0.6-1.5 mm, large - ca. 1.5-3 mm wide. We use definition "rather large" when shoot width exceeds $1.5 \mathrm{~mm}$ slightly, till $1.7 \mathrm{~mm}$ mostly.

Data on distribution and ecology of Russian Cephalozia are listed in comments to the species and based chiefly on «Annotated list of liverworts and hornworts of Russia» (Potemkin, Sofronova, 2009) to avoid excessive references. Only papers published later or omitted by Potemkin and Sofronova (2009) are cited for definition of distribution in Russia. Data on World distribution are based on accounts in regional treatments of the genus (Schuster, 1974; Ván̆a, 1988; Damsholt, 2002 mostly) and regional check-list and treatments (Dietzov, 1938, Váňa, 1988, 1993; Piippo, 1990; Yamada \& Iwatsuki, 2006) in some cases accomplished by data from Dierssen (2001). Only selected specimens from Russia and adjacent territories are cited to represent species variability and characteristic morphotypes.

\section{KEY TO MORPHOLOGICAL GROUPS OF CEPHALOZIA}

1. Leaves strongly constricted at base, very shortly subtransversely or hardly incubously inserted with line of insertion at least 3-5 times shorter than leaf width, asymmetrically bilobed, postical part of lamina inflated, extended and folded back to form postical lobule; lobes terminated in long ciliate (mostly 4-7 cells long) decurved apex

Group I Nowellia (C. curvifolia) (Fig. 1)

- Leaves not constricted at base, succubously to subtransversely inserted with line of insertion (0.85-)11.5(-2) leaf width, postical part of lumina never inflated and never form postical lobule; lobes acute, acuminate or short ciliate ( $2-5$ cells long), very rare obtuse to rounded 

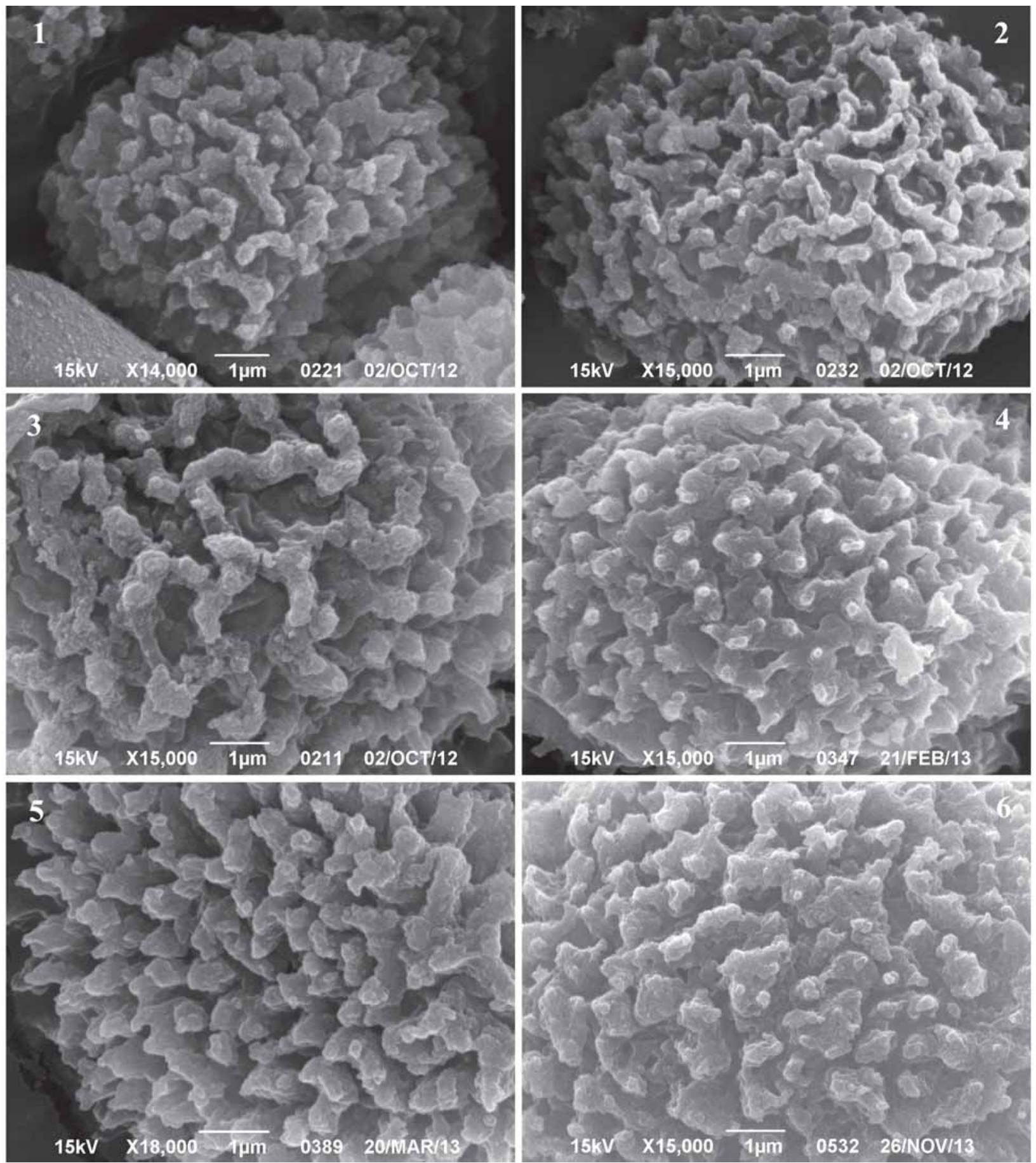

Fig. 5. Spore surface structure of Cephalozia affinis (1), C. lunulifolia (2), C. pleniceps (3, 4), C. monticola (5), C. albescens (6). 1 - from Novgorod Region, Potemkin 70612-1;2 - from Novgorod Region, Potemkin 70612-2; 3 - Yamal Peninsula, 12.VIII.1978 E. N. Andrejeva; 4 -Kabardino-Balkaria, 20.VIII.2010 V.M. Kotkova № 479; 5 - Washington, Potemkin 9522 01; 6 - from Kamchatka Peninsula, Vulcano Burlyashchiy, 6.VIII.2012 Neshataeva \#MT-50; all in LE.

2. Plants (1-)1.5-3 mm wide; leaves canaliculate with shallow sinus (0.15-)0.2-0.4 their length; stem fleshy, without hyalodermis. Far East

Group II Schofieldia (C. monticola) (Fig. 1)

- Plants smaller, less than 1(-1.5) mm wide; leaves plane to concave, mostly not canaliculate with deeper sinus, (0.25-)0.35-0.65(-0.8) leaf length; stem with \pm distinct hyalodermis (except $C$. pachycaulis) .... 3
3. Underleaves large and patent, present throughout on sterile shoots, lanceolate to nearly ovate, often nearly as long as leaves; secondary pigmentation lacking .... Group III Pleurocladula (C. albescens) (Fig. 1)

- Underleaves usually lacking on sterile shoots; secondary pigmentation lacking or present ............. 4

4. Hyalodermis lacking or indistinct on mature stems ... Group IV Pachycaules (C. pachycaulis) (Fig. 2) 

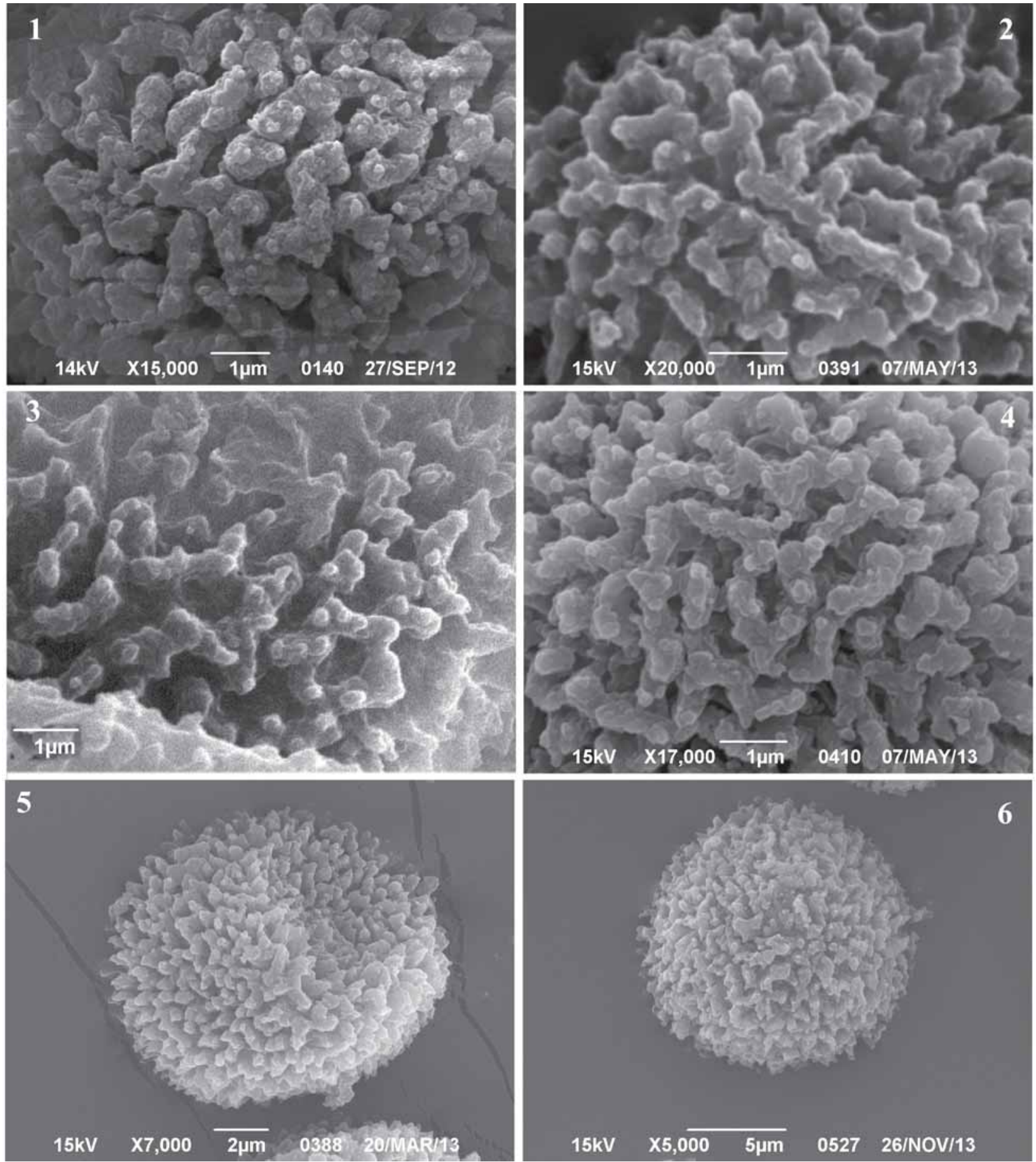

Fig. 6. Spore surface of Cephalozia bicuspidata (1), C. macounii (2), C. loitlesbergeri (3) and C. connivens (4), spores of $C$. monticola (5) and C. albescens (6). 1 - from Leningrad Region,Veppskiy Les, 24-27.V.2007 Potemkin; 2 - Republic of Komi, 8.VIII.1999 М. V. Dulin 154МВД Dulin; 3 - West Siberia, 21.VII.2000 I. V. Czernyadjeva; 4 -Bryotheca Baltica 183; 5 - USA: Washington, Potemkin \#95 22016 - from Kamchatka Peninsula, 6.VIII.2012 Neshataeva \#MT-50; all in LE.

- Hyalodermis distinct 5

5. Leaves slightly broader or longer than wide (length/ width ratio mostly $0.8-1.1(-1.3): 1),(4-) 8-21(-31)$ cells wide, sinus (025-)0.35-0.65(-0.8) leaf length; plants rather large to minute, $(0.15-) 0.3-1.7 \mathrm{~mm}$ wide, often \pm pellucid 6

- Leaves considerably longer than wide [length/width ratio (1.2-)1.5-2: 1], (4-)5-8(-10) cells wide, divid- ed into two narrow spinous lobes by deep sinus, ca. $0.55-0.8$ leaf length; plants minute, $0.12-0.2(-0.35)$ mm wide, tender and never pellucid

Group VI Macouniae (C. macounii) (Fig. 2)

6. Leaves about as wide as stem, remote and not conceal stem, scale-like, often with smaller postical part, cells of leaves distinctly to slightly thick-walled .... Group IX Leucanthae (C. leucantha) (Fig. 3) 

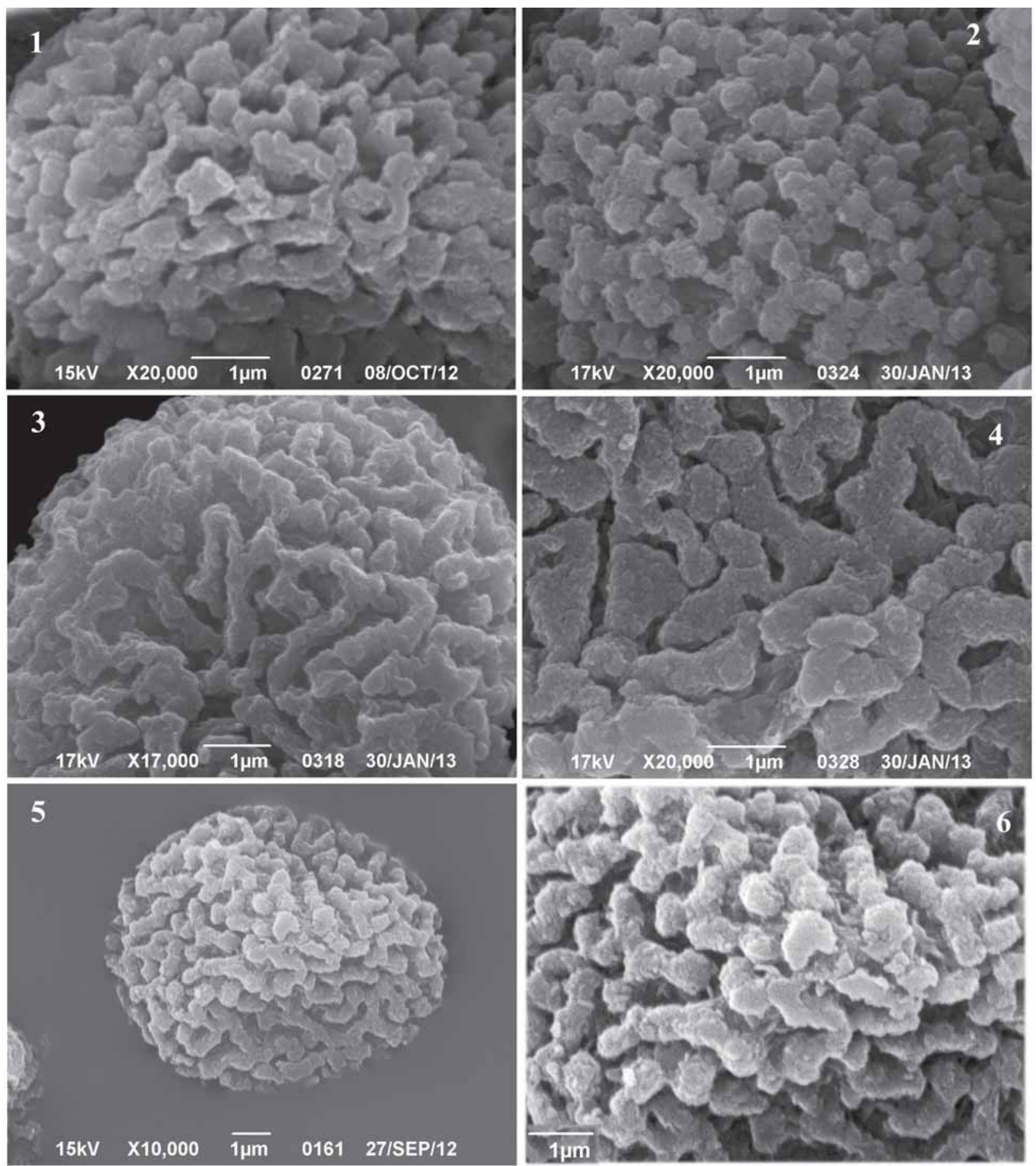

Fig. 7. Spore surface structure of Cephalozia leucantha (1), C. catenulata s. str. (2), C. catenulata var. reclusa (3), C. catenulata subsp. nipponica (4), C. curvifolia (5, 6). 1 - from Leningrad Region, 8.VII.1989 Potemkin; 2 - Poland, Hep. Beskidi Silesis Exs. 21; 3 Hepatotheca Polonica Fasc. 1. 20; 4 - S. Hattori: Hepaticae Japonicae. 158; 5, 6 - Novgorod Region. 6.VI.2012 Potemkin (.) 453; all in LE.

- Leaves considerably wider than stem, subimbricate to remote, conceal stem when dense, not scale-like, often with larger postical part

7. Antical end of leaf insertion line extending on to median cortical cells; leaves \pm bilaterally symmetric Group V Cephalozia (C. ambigua, C. bicuspidata, C. hamatiloba) (Fig. 2)

- Antical leaf-free zone (1-)2(-3) cells wide, mostly distinct; leaves often asymmetric: postical margin stronger convex than antical margin 8

8. Terminal cell wall of leaf lobes stronger thickened at apex; terminal Frullania-type branches unknown, stolons known in C. loitlesbergeri only; hyalodermis distinct, antical leaf-free zone usually distinct, 2 cells wide

Group VIII Obscurae (species of sections Catenulatae, Lacinulatae and Lunulifoliae - Figs. 3 (except C. leucantha), 4 (except C. pleniceps)) 

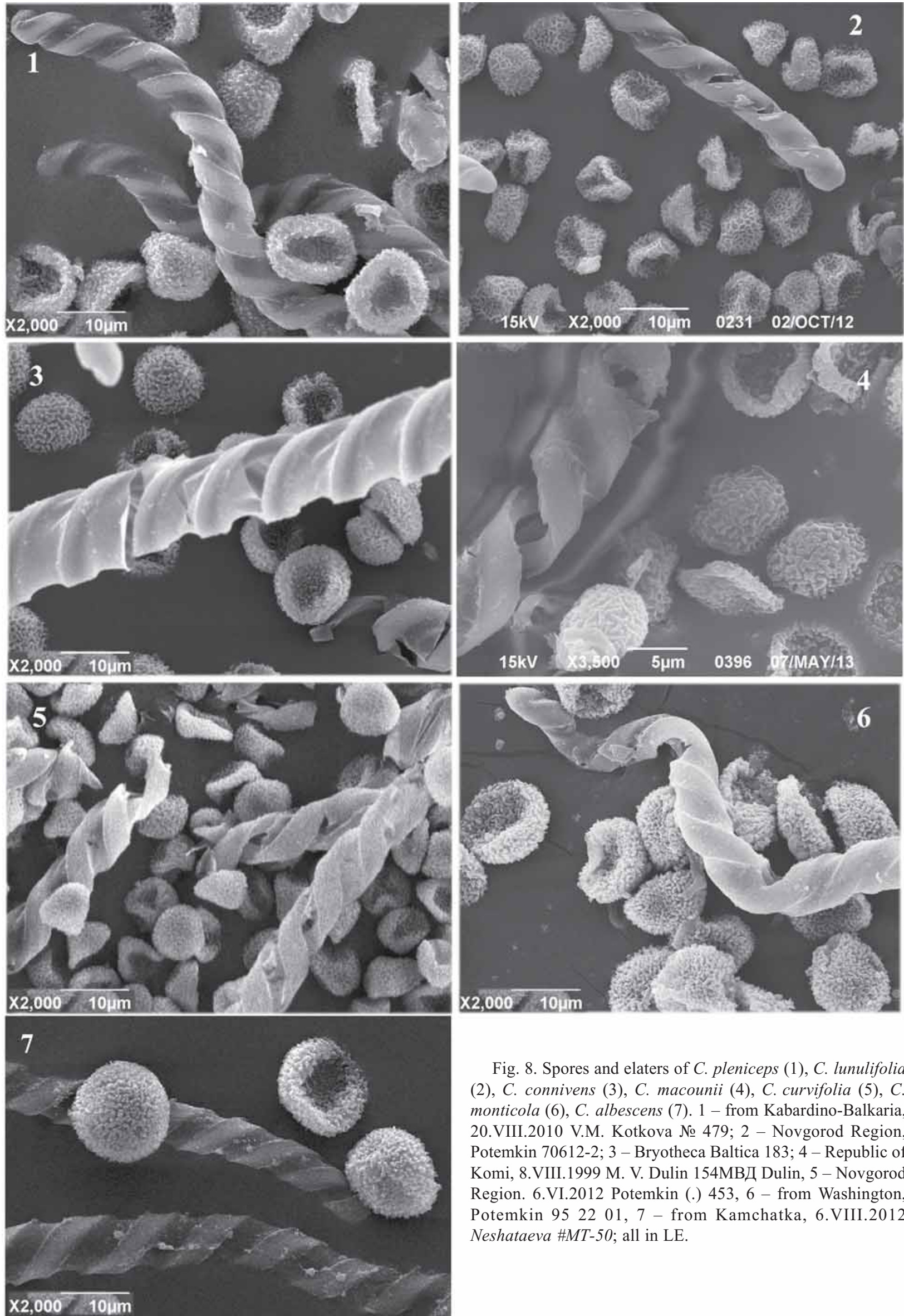

Fig. 8. Spores and elaters of C. pleniceps (1), C. lunulifolia (2), C. connivens (3), C. macounii (4), C. curvifolia (5), C. monticola (6), C. albescens (7). 1 - from Kabardino-Balkaria, 20.VIII.2010 V.M. Kotkova № 479; 2 - Novgorod Region, Potemkin 70612-2; 3 - Bryotheca Baltica 183; 4 - Republic of Komi, 8.VIII.1999 M. V. Dulin 154МВД Dulin, 5 - Novgorod Region. 6.VI.2012 Potemkin (.) 453, 6 - from Washington, Potemkin 9522 01, 7 - from Kamchatka, 6.VIII.2012 Neshataeva \#MT-50; all in LE. 
- Terminal cell wall of leaf lobes evenly slightly thickened at apex; terminal Frullania-type branches and stolons sporadically present; hyalodermis often weakly defined: outer cells gradually intergrade into medullary cells, antical leaf-free zone sometimes indistinct, (1-)2(-3) cells wide

Group VII Pleniceps (C. pleniceps - Fig. 4)

\section{KEY TO RUSSIAN SPECIES OF CEPHALOZIA}

1. Leaves strongly constricted at base, very shortly subtransversely or hardly incubously inserted with line of insertion at least 3-5 times shorter than leaf width, asymmetrically bilobed, postical part of lamina inflated, extended and folded back to form a postical lobule; lobes terminated in a long ciliate (mostly 47 cells long) decurved apex .. C. curvifolia (Fig. 1)

- Leaves slightly or not constricted at base, succubously to subtransversely inserted with line of insertion (0.85-)1-1.5(-2) times shorter than leaf width, postical part of lumina never inflated and never form postical lobule; lobes acute, acuminate or short ciliate (2-5 cells long), very rare obtuse to rounded .. 2

2. Plants (1-)1.5-3 mm wide; leaves canaliculate with shallow sinus (0.15-)0.2-0.4 leaf length; stem fleshy, without hyalodermis. Far East C. monticola (Fig. 1)

- Plants smaller, less than 1(-1.5) mm wide; leaves plane to concave, mostly not canaliculate with deeper sinus (0.25-)0.35-0.65(-0.8) leaf length; stem with \pm distinct hyalodermis (except $C$. pachycaulis)... 3

3. Underleaves large present throughout on sterile shoots, \pm lanceolate to nearly ovate, often nearly as long as leaves; secondary pigmentation lacking .....

C. albescens (Fig. 1)

- Sterile shoots nearly always without underleaves; secondary pigmentation absent or present ........... 4

4. Medium-size to rather large and minute, (0.15-)0.31.5(-1.7) mm wide, often \pm pellucid, mostly with \pm superficially distinct hyalodermis of thin- to somewhat thick-walled cells; leaves wider than stem or rare as wide as the stem, (4-)8-21(-31) cells wide, mostly not much longer than wide (length/width ratio mostly $0.8-1.1(-1.3)$ : 1$)$; sinus (025-)0.35-0.65($0.8)$ leaf length

- Minute, 0.12-0.2(-0.35) mm wide, tender and never pellucid xylicolous plants with thin stem [(35-)45$60(-85) \mu \mathrm{m}$ wide] and superficially indistinct hyalodermis of \pm thick-walled cells; leaves about as wide as stem, (4-)5-8(-10) cells wide, considerably longer than wide [length/width ratio (1.2-)1.5-2: 1] divided into two narrow lobes by deep sinus, ca. $0.55-$ 0.8 leaf length C. macounii (Fig. 2)

See $C$. macounii, C. catenulata, $C$. leucantha comments below for their differentiation.

5. Antical end of leaf insertion extends to median cortical cells, sometimes almost to antical mid-line of sterile stems; walls of medullary cells \pm thin or moderately thickened often like cortical cells; terminal branches often present ...................................... 6

- Antical ends of leaf insertion do not extend to antical mid-line on sterile stems (except androecia and gynoecia) and space antical leaf-free zone (1-)2(-3) cells wide; walls of medullary cells mostly thicker than walls of cortical cells or occasionally \pm thin like walls of cortical cells; terminal branches lacking except C. pleniceps and C. pachycaulis .............. 9

6. Leaves of mature shoots with maximal width mostly between lower and middle thirds

- Leaves of mature shoots with maximal width often near middle ................................... 8

7. Leaf sinus $0.5-0.75$ leaf length, rarely less deep in plants of mod. parvifolia-densifolia; secondary pigmentation, if present, mostly brown, in arctic plants often also purplish brown to purple; autoicous. Widespread C. bicuspidata p. max. p. (Fig. 2) See C. ambigua, C. bicuspidata, C. lacinulata, C. hamatiloba comments for their differentiation.

- Leaf sinus 0.4-0.5 leaf length mostly; secondary pigmentation lacking or mostly violet; dioicous. Far East C. hamatiloba (C. otaruensis var. acrogyna phenotype) (Fig. 2) See C. ambigua, C. bicuspidata, C. lacinulata, C. hamatiloba comments for their differentiation.

8. Plants light green, brown, fuscous, brownish black or purplish brown; leaves about as long as wide or a little longer than wide; leaf sinus (0.3-)0.4-0.5(-0.6) leaf length; lobes \pm acute, with 1-2 celled uniseriate ends, to very rare blunt and rounded; lobe cells often nearly isodiametric or slightly elongate, at lobe bases (15-)17-25(-30) $\mu \mathrm{m}$ wide; antical cortical cells mostly $1.5-2.5 \times$ as wide as medullary cells; autoicous; perianth mouth crenulate-denticulate with hardly projected ends of marginal cells. Arctic-alpine species. On soil and rocks ............ C. ambigua (Fig. 2) See $C$. ambigua, C. bicuspidata, C. leucantha var. robus$t a, C$. hamatiloba comments for their differentiation.

- Plants usually light green; leaves about as long as wide or distinctly longer than wide, sinus (0.5-)0.6$0.75(-0.8)$ leaf length; lobes \pm acute with $1-2(-3)$ celled uniseriate ends, as an exception singular lobes blunt or rounded; lobe cells mostly elongate, at lobe bases (17-)20-30(-35) $\mu \mathrm{m}$ wide; antical cortical cells often 2.5-3× as wide as medullar cells; dioicous; perianth mouth broadly lobulate dentate with 1-3-celled teeth of elongate cells. On rotten wood, soil and rocks. Far East C. hamatiloba (Fig. 2) (C. dubia and C. otaruensis var. setiloba phenotypes) See C. bicuspidata, C. lacinulata, C. hamatiloba comments for their differentiation.

9(5). Sterile leaves \pm remote to subimbricate, inserted along stem or more rarely at considerable angle to stem; leaf width considerably exceeds stem width, at least on mature shoots; leafy shoots $(0.2-) 0.4-1.5(-1.75) \mathrm{mm}$ wide; monoicous or more rare dioicous 10 
- Sterile leaves usually small and distant, not conceal stem, inserted nearly transversely or at considerable angle to stem; leaf width similar or slightly exceeds stem width; leafy shoots often look worm-like, 0.150.3(-0.4) mm wide; dioicous C. leucantha (Fig. 3) See $C$. leucantha comments below for its differentiation from C. macounii, C. catenulata.

10. Plants light green, mostly not developing brown pigmentation in exposed sunny places, \pm pellucid; leaf cells chiefly thin-walled, mostly over $24 \mu \mathrm{m}$ at lobe base (if plants \pm brownish, lobes with uniseriate ends of 2-3 cells or colour resulted from destruction of older shoot sectors and/or from cell content rather than pigmentation of cell walls); female bracts mostly entire .. 11

- Plants in \pm exposed sunny habitats develop brown pigmentation at least in medulla of old shoot sectors, \pm opaque; leaf cells often \pm thick-walled, mostly below $25 \mu \mathrm{m}$ wide; leaf lobes with uniseriate ends of 1-2(3) cells; female bracts \pm dentate to subentire ........ 23

11. Plants monoicous or dioicous, usually $0.5-1.5 \mathrm{~mm}$ wide; leaves over 8 cells wide. On diverse substrata

12

- Plants dioicous small and tender, 0.3-0.55 mm wide; leaves 4-7(-8) cells wide; (cells of leaf and stem large, pellucid; usually fertile; perianth mouth narrowly laciniate-ciliate with lacinae $2-6$ cells wide, $4-7$ cells long, with uniseriate ends $2-3$ cells long). Only on rotten wood in forests with constantly high air humidity. Very rare

C. lacinulata (Fig. 3) See $C$. lacinulata comments below for its differentiation from mod. parvifolia-angustifolia-laxifolia of C. bicuspidata, $C$. hamatiloba and juvenile $C$. connivens.

12. Leaves bilaterally \pm asymmetric: in lower third with concave or straight antical margin and convex postical margin; leaves as wide as long or wider than long . 13

- Leaves bilaterally \pm symmetric, in lower third with \pm similar (mostly straight or convex) antical and postical margins; leaves longer than wide or about as wide as long 21

13. Plants with perianths 14

- Plants without perianths 18

14. Perianth mouth crenulate or with 1-2-celled teeth or cilia; dioicous and monoicous 15

- Perianth mouth \pm laciniate, lobulate-ciliate or dentate-ciliate, with cilia of 2-5(-6) elongate cells; monoicous (autoicous) 17

15. Uniseriate lobe ends pointed, chiefly with stronger thickened wall at apex, of 1-2 cells, 20-35(-38) $\mu \mathrm{m}$ at base; leaves plane or rare concave in plants of mod. parvifolia-densifolia, with antical margin inserted along stem and \pm distinctly decurrent; antical leaf-free zone mostly distinct; stolons and terminal branches lacking; ends of rhizoids branched or indistinctly swollen; dioicous or autoicous; spores small, $8-10 \mu \mathrm{m}$, with fine reticulate areolation (LM data); spore/elater diameter ratio about 1.5: 1 ................................. 16

- Uniseriate lobe ends often \pm blunted, of 1(-2) cells, without stronger thickened apical wall, ca. (23-)35$55(-65) \mu \mathrm{m}$ at base; leaves often \pm concave (except plants of mod. laxifolia) with insertion of antical margin subtransverse or at angle to stem, undecurrent or in mod. laxifolia \pm distinctly decurrent; antical leaffree zone often indistinct and/or of variable width, 13 cells wide; stolons and terminal branches may present; ends of rhizoids often swollen; autoicous; spores larger, (11-)12-16.5(-21) $\mu \mathrm{m}$, with fine papillose-vermiculate areolation (LM data); spore/elater diameter ratio about 2: 1 ........ C. pleniceps (Fig. 4) See C. affinis, C. connivens, C. pachycaulis, C. pleniceps comments for their differentiation.

16. Dioicous; androecia on main shoot or on short lateral branches; perianth mouth crenulate-dentate with teeth 0.5-1.5(-2) cells long . C. Iunulifolia (Fig. 4) See $C$. affinis, $C$. catenulata, $C$. leucantha var. robusta, C. macrostachya, C. pleniceps comments for their differentiaton.

- Monoicous; androecia minute spicate mostly close to branch with perianth; perianth mouth lobulatedentate, with teeth often $2-3$ cells long

C. affinis (Fig. 4)

See $C$. affinis, C. pleniceps comments for their differentiation.

17(14).Uniseriate lobe ends of (1-)2-3 cells, often \pm connivent and sometimes crossing, their terminal cell at base $12-20(-22) \mu \mathrm{m}$ wide

C. loitlesbergeri (Fig. 3)

See $C$. connivens, $C$. loitlesbergeri, $C$. macrostachya comments for their differentiation.

- Uniseriate lobe ends of 1-2(-3) cells, often somewhat to distinctly connivent but as a rule not crossing, their terminal cells at base $22-38 \mu \mathrm{m}$ wide.....

C. connivens (Fig. 3)

See C. connivens, C. lacinulata, C. loitlesbergeri, C. pleniceps comments for their differentiation.

18(13).Uniseriate lobe ends often \pm blunted [of 1(-2) cells, (23-)35-55(-65) $\mu \mathrm{m}$ at base], cell wall slightly evenly thickened at apex; leaves not rare \pm concave (except plants of mod. laxifolia), insertion of their antical margin subtransverse or at angle to stem, undecurrent or in mod. laxifolia \pm distinctly decurrent; stolons and terminal branches sometimes present..

C. pleniceps (Fig. 4)

See C. affinis, C. connivens, C. pachycaulis, C. pleniceps comments for their differentiation.

- Uniseriate lobe ends pointed, cell wall at apex chiefly stronger thickened; leaves plane or rare concave, with antical margin inserted \pm along stem and often distinctly decurrent; stolons and terminal branches lacking (rare in C. loitlesbergeri) 19

19. Lobes mostly not or slightly connivent, never cross- 
ing each other; uniseriate ends of lobes of 1-2 cells; leaves inserted along or at some angle to stem .......

C. Iunulifolia, C. affinis (Fig. 4)

- Lobes usually \pm connivent and sometimes crossing each other; uniseriate ends of lobes of $1-2$ or $2-3$ cells; leaves inserted along stem 20

20. Uniseriate lobe ends of $1-2(-3)$ cells, nearly never crossing; terminal cells $22-38 \mu \mathrm{m}$ wide at base of $1-$ 2-celled uniseriate ends; brown pigmentation of cell walls unknown C. connivens (Fig. 3) See C. connivens, C. lacinulata, C. loitlesbergeri, C. pleniceps comments for their differentiation.

- Uniseriate lobe ends of (1-)2-3 cells, sometimes or often crossing; terminal cells $12-20(-22) \mu \mathrm{m}$ wide at base; brown pigmentation of cell walls may present C. loitlesbergeri (Fig. 3)

See $C$. connivens, C. loitlesbergeri, C. macrostachya comments for their differentiation.

21(12). Leaf lobes never ciliate and sometimes \pm blunted; uniseriate ends of lobes of 1(-2) cells; hyalodermis \pm distinct; maximal width of leaves mostly near middle. Widespread 22

- Leaf lobes acuminate, \pm ciliate or acute. Uniseriate ends of lobes of (1-)2-3(-4) cells; hyalodermis mostly indistinct; maximal width of leaves chiefly in lower third, rare near middle. South Siberia, Far East .....

C. pachycaulis (Fig. 2) See C. pachycaulis, C. pleniceps comments for their differentiation.

22. Terminal cell wall of uniseriate ends of lobes not stronger thickened at apex; uniseriate end of lobes (23)35-55(-65) $\mu \mathrm{m}$ wide at base; cells at base of lobes (25)33-40(-50) $\times 40-50(-55) \mu \mathrm{m}$; cells of antical surface of stem (30)40-50(-75) ×(40)50-100(-150) $\mu \mathrm{m}$ long; terminal branching and stolons may present; perianth mouth crenulate to short dentate

C. pleniceps (Fig. 4)

See C. affinis, C. connivens, C. pachycaulis, C. pleniceps comments for their differentiation.

- Terminal cell wall of uniseriate ends of lobes mostly stronger thickened at apex; uniseriate ends of lobes (25-)30-37(-40) $\mu \mathrm{m}$ wide at base; cells at base of lobes $20-35(-37) \times 25-35(-40) \mu \mathrm{m}$; cells of antical surface of stem $25-40(-50) \times 35-60(-100) \mu \mathrm{m}$ long; terminal branching and stolons lacking; perianth mouth lobulate-dentate or lobulate-ciliate, with teeth or cilia 2-3 cells long C. affinis (Fig. 4) See $C$. affinis, C. pleniceps comments for their differentiation.

23(10). Plants (0.3-)0.5-1(-1.1) mm wide; sterile leaves inserted along stem, often shallowly canaliculate with \pm connivent lobes that makes sinus hardly discernible when observed with hand-lens; cells of lobes distinctly smaller and with thicker walls than cells of undivided part of leaf, $17-25(-30) \times 22-36 \mu \mathrm{m}$ vs. $28-45(-48) \times 40-60(-65) \mu \mathrm{m}$; antical cortical cells (20-)25-45(-48) ×35-60(-80) $\mu \mathrm{m}$; female bracts with rather deep sinus, 0.5-0.75 their length. Subatlantic species, on upper mires in getting dry black pools and among Sphagnum .... C. macrostachya (Fig. 3) See C. catenulata, C. loitlesbergeri, C. macrostachya comments for their differentiation.

- Plants smaller, 0.2-0.4(-0.6) mm wide; sterile leaves inserted obliquely or along stem (as an exception subtransversely); cells of lobes often \pm thick-walled, $13-20(-24) \times 20-25(-28) \mu \mathrm{m}$, and $23-25 \times 25-30(-35)$ $\mu \mathrm{m}$ in undivided part of leaf; antical cortical cells 16-28 $\times 25-45 \mu \mathrm{m}$; female bracts with rather shallow sinus, $0.25-0.4(-0.5)$ their length. Amphioceanic species, on rotten wood, very rare on peat, wet sandstone, and granite rocks

C. catenulata (Fig. 3)

See C. catenulata comment below for its differentiation from C. macounii, C. leucantha and C. lunulifolia.

\section{Group I Nowellia (Cephalozia curvifolia)}

Plants medium-size to small, often purple and/or brown. Branches sporadic terminal Frullania-type and postical intercalary, lateral intercalary branches rare, stolons lacking. Stem thin and rigid, with distinct hyalodermis, without antical leaf-free zone, antical cortical cells much broader than basal leaf cells. Leaves much broader than stem, about as wide as long, strongly constricted at the base, very shortly subtransversely or hardly incubously inserted, undecurrent, asymmetrically $0.5-0.6$ ($0.65)$-bilobed, postical half of leaf larger than antical, postical part of lamina inflated, extended and folded back to form a postical lobule; lobes terminated in a long ciliate decurved apex, terminal cell wall slightly stronger thickened at apex. Underleaves lacking on sterile shoots.

Cephalozia curvifolia (Dicks.) Dumort., 1835. Recueil Observ. Jungerm.: 18. — Jungermannia curvifolia Dicks., 1790. Fasc. P1. Crytogam. Brit. 2: 15. - Nowellia curvifolia (Dicks.) Mitt. 1870. Nat. Hist. Azores, or Western Islands: 321. — Figs. 1, 7: 5, 6, 8: 5.

Plants medium-size to small, whitish green to deep purple, rare \pm brown to fuscous. Branches sporadic terminal Frullania-type and postical intercalary, lateral intercalary branches rare, stolons lacking. Stem thin, with distinct \pm thick-walled hyalodermis and \pm thin-walled medullary cells, without antical leaf-free zone that sometimes appears to be \pm obvious (leaf bases finely attached to outer margin of cells of neighbour antical cell rows); antical cortical cells ca. $(25-) 40-50(-55) \times 25-50(-75) \mu \mathrm{m}$, thick- to thin-walled, sometimes wider than long. Rhizoids with not branched ends. Leaves asymmetrically bilobed, postical part of lamina inflated, extended and folded back to form a postical lobule; lobes terminating in a long ciliate decurved apex; juvenile leaves and leaves on diminutive shoots almost symmetrically bilobed, without postical sac; leaves strongly constricted at base, very shortly subtransversely or hardly incubously inserted with line of insertion at least 3-5 times shorter than leaf width, obliquely broadly ovate to oblong-ovate and obovate, \pm 
concave, undecurrent - base of antical margin \pm transversely inserted; maximal leaf width near the middle or between the middle and lower thirds; sinus rectangular, V- or U-like, 0.5-0.6(-0.65) leaf length; lobes abruptly narrowed into ciliate decurved ends. Uniseriate ends of lobes (2-)4-7(-10) cells long, terminal cell wall \pm indistinctly stronger thickened at the apex. Lobe cells at the lobe bases $(15-) 20-25(-28) \times 20-30(-35) \mu \mathrm{m}, \pm$ thick- to thin-walled. Dioicous, autoicous or paroicous. Female bracts bilobed for ca. 0.15-0.5 their length, in upper half subdentate to serrate and spinous-dentate or subentire with single remote denticulations. Perianth mouth lobulate-ciliate or spinous-dentate and denticulate with remote denticulations of cell projections mostly. Spores ca. (7-)8-10(-11) $\mu \mathrm{m}$, densely vermiculate reticulate (SEM), about as wide as elaters.

Selected illustrations: Müller, 1951-1958: Fig. 420; Grolle, 1968: Abb. 1-3; Schuster, 1974: Fig. 465-466; Schljakov, 1979: Рис. 34; Paton, 1999: Fig. 42; Damsholt, 2002: P1. 197.

World distribution. Europe, Macaronesia, Suboceanic Asia, Phillipines, Indonesia, Malaysia, eastern North America, Central America, northern South America, NE Australia (Pycs et al., 2012).

Distribution in Russia. Restricted by mostly suboceanic areas or intracontinental areas with humid microclimate in European Russia, Caucasus and the Russian Far East. From South taiga subzone and mountain taiga to mountain subtropical forests in Caucasus. Unknown from Siberia.

Ecology. Mostly on moist decaying logs, rare on rather dry decaying logs, rocks and humus over rocks, usually in high humidity areas, i.e. in old growth forests and areas with \pm humid microclimate.

Selected specimens examined: Leningrad Province: Kiperort Peninsula, on rotten stump ..., Potemkin \#140812-1 (LE) (per., fr.); Novgorod Province: Khvoyninsky District, ... on follen decorticated slightly decomposed trunk of pine, Potemkin \#(.) 453 (LE) (fr.); Pskov Province: Pskovsky Modelny Les, 4.X.2007, Kotkova s.n. (LE) (per.); Tver Province: ... on decayng wood of black alder ..., Potemkin \#100813-5 (LE) (mod. laxifolia-viridis with cilia up to 9 cells long, one bifurcate cilium seen); Orel Province: ... on spruce log, Kotkova \#OP-09$93 a$ (LE) (per.); Republic of Karachaevo-Cherkessia: Teberda, on rotten pine stump, 10.VIII.1955, Abramovs s.n. (LE) (fr.); Primorsky Territory: Shkotovky District, fir forest, on decaying wood, 9.X.2005, Bakalin s.n. (LE) (per., mod. subleptoderma with perianth mouth and female bracts subentire to dentate).

\section{Group II Schofieldia (Cephalozia monticola)}

Plants large, without secondary pigmentation. Branches sporadic terminal Frullania-type, occasionally postical intercalary, stolons unknown. Stem thick and fleshy, without hyalodermis and antical leaf-free zone, antical cortical cells much broader than basal leaf cells. Leaves much broader than stem, about as wide as long, slightly constricted at the base, with transversely inserted antical leaf base and obliquely succubously inserted postical leaf base, undecurrent, canaliculate, nearly symmetrically (0.15-)0.2-0.4-bilobed, postical half of leaf often larger than antical, postical margin somewhat stronger convex and acute to rounded lobes, terminal cell wall evenly thickened. Underleaves variable in size and shape, appressed to stem, often indistinct.

Cephalozia monticola (J.D. Godfrey) Potemkin \& Sofronova, comb. nov. - Schofieldia monticola J.D. Godfrey, 1976. Bryologist 79: 315. — Pleurocladula monticola (J. D. Godfrey) Konstant., Vilnet et Troitsky, 2012. Arctoa 21: 125. - Fuscocephaloziopsis monticola (J. D. Godfrey) Váňa et L. Söderstr., 2013. Phytotaxa 112(1): 11. Figs. 1, 5: 5, 6: 5, 8: 6 .

Plants large whitish green, soft-textured tender fleshy and pellucid. Branches sporadic, mostly terminal Frullania-type, occasionally postical intercalary, stolons unknown. Stem soft of tender thin-walled cells, with smaller outer and somewhat larger inner cells, without antical leaf-free zone; postical leaf-free zone broad, ca. 8-10 cells; antical cortical cells, ca. (27-)35-75×(50-)60-130 $\mu \mathrm{m}$. Rhizoids often long and dense colorless or brownish, sometimes with swollen ends. Leaves \pm ovate with \pm stronger convex postical base and somewhat longer postical lobe, about as wide as long or wider than long; maximal width mostly in the lower third or between the middle or lower thirds, canaliculate to conduplicate due to transversely inserted antical leaf base and obliquely succubously inserted postical leaf base, undecurrent; sinus mostly $\gamma$-like, sometimes V-like, (0.15-)0.2-0.4 leaflength; lobes narrowly triangular acute to blunt and rounded. Uniseriate ends of lobes of mostly of 1 cell, sometimes 2-celled, once seen 3-celled, terminal cell wall evenly or hardly stronger thickened at the apex, sometimes very finely verruculose. Leaf cells very thin-walled or with slightly thickened walls with small distinct trigones, at base of lobes ca. (20-)25-35(-40)×25-50(-65) $\mu \mathrm{m}$, distinctly larger in the lower part of leaves. Underleaves often indistinct among dense rhizoids, variable in size, from minute of a few cells to large scale-like. Dioicous. Female bracts like leaves, larger, longer than wide, with entire margins. Perianth mouth shallowly lobed, crenulate to denticulate. Spores ca. 12-13.5 $\mu \mathrm{m}$ (up to16 $\mu \mathrm{m}$ according to Godfrey, 1976), echinate (SEM), from nearly as wide as elaters to about $2 \times$ as wide as elaters.

Differentiation. Cephalozia monticola is rather easily identified species due to its unique morphology for the family Cephaloziaceae. In leaf shape it resembles Lophozia excisa (Dicks.) Dumort., L. polaris (R.M. Schust.) R.M. Schust. \& Damsh. and related species. However, total lack of secondary pigmentation, of mycorrhiza and oil bodies as well as distinctive canaliculate leaves, Cephalozioid sporophyte and gemmae distinguish C. monticola from representatives of the genus Lophozia (Dumort.) Dumort. and the other genera of hepatics. $C$. monticola may be confused also with Nardia insecta. It is distinct from the latter in somewhat larger and broad- 
er postical (vs. antical) leaf lobes, mostly indistinct scalelike underleaves and trigones, lacking of oil bodies and some other above mentioned characters.

Selected illustrations: Godfrey, 1976: Figs. 1-24; Bakalin 2005: Fig. 1; Potemkin, Sofronova, 2009: 131, Fig. 71.

World distribution. Nothern Amphipacific species: USA: Washington; Canada: British Columbia; Russia: Kamchatka Peninsula.

Distribution in Russia. Nothern Kamchatka Peninsula.

Ecology. On soil in alpine brookside communities, in wet moss tundra and hot springs areas in N. Kamchatka and in sheltered niches under heather in North America.

Selected specimens examined: RUSSIA: Kamchatsky Territory: Northern Kamchatka, Upper Palana River, $650 \mathrm{~m}$ alt., 11.VII.2003, Bakalin s.n. (LE). CANADA: British Columbia: Mt. Baker National Forest, humusy streamlet bank in meadow, under Cassiope mertensiana and Phylodoce empetriformis, Godfreys \#3330 (LE); USA: Washington: bank of stream, on soil, $4650 \mathrm{ft}$. alt., Potemkin \#95 2201 (LE) (fr., seta of 5+9 type).

\section{Group III Pleurocladula (Cephalozia albescens)}

Plants medium-size to small, without secondary pigmentation. Branches terminal Frullania-type and lateral intercalary, as an exception postical intercalary (mentioned in mod. laxifolia), stolons lacking. Stem with distinct hyalodermis, without antical leaf-free zone, antical cortical cells about as broad as basal leaf cells. Leaves much broader than stem, about as wide as long, moderately constricted at the base with transversely inserted antical leaf base and oblique succubously inserted postical leaf base, undecurrent, concave, nearly symmetrically (0.3-)0.35-0.5(-0.67)-bilobed, postical half of leaf often larger than antical, lobes acute to blunt, terminal cell wall evenly thickened. Underleaves patent, nearly as long as leaves, ovate, ovate-lanceolate or lanceolate.

Cephalozia albescens (Hook.) Dumort., 1835. Recueil Observ. Jungerm.: 18. — Jungermannia albescens Hook., 1816. Brit. Jungerm.: 14. - Jungermannia islandica Nees, 1836. Naturgesch. Eur. Leberm. 2: 5, 29. - Cephalozia islandica Lindb., 1879. Musci scand.: 3. - Pleuroclada albescens (Hook.) Spruce, 1886. On Cephalozia : 78, nom. illeg. - Pleuroclada islandica (Nees) Pears., 1900. Hep. Brit. Isl.: 194, nom. illeg. — Pleurocladula albescens (Hook.) Grolle, 1979. J. Bryol. 10: 269. — Pleurocladula islandica (Nees) Grolle, 1979. J. Bryol. 10: 269. — Pleurocladula albescens var. islandica (Nees) L. Söderstr. \& Váňa, 2002. Lindbergia 27: 43. — Fuscocephaloziopsis albescens (Hook.) Váňa \& L. Söderstr., 2013. Phytotaxa 112(1): 9. - Figs. 1, 5: 6, 6: 6, 8: 7.

Plants medium-size to small, whitish green. Branches terminal Frullania-type and lateral intercalary, as an exception postical intercalary (mentioned in mod. laxifolia), stolons lacking. Stem with \pm distinct hyalodermis of slightly to moderately thick-walled elongate cells, medullary cells thin-walled to rather strongly evenly thick-walled, without antical leaf-free zone; cells of antical surface of stem ca. $20-40(-50) \times 25-70(-110) \mu \mathrm{m}$. Rhizoids sometimes with swollen or hardly branched ends. Leaves suborbicular, rounded quadrate, broadly ovate to oblong-ovate, \pm concave, undecurrent - base of antical margin \pm transversely inserted, postical margin succubously inserted, its base occasionally with lobe-like tooth; maximal leaf width between the middle and lower thirds or near the middle; postical margin convex like antical margin; sinus $\mathrm{V}$ - or $\gamma$ like, (0.3-)0.35-0.5(-0.67) lobe length; lobes acute or very rare obtuse to rounded, straight. Uniseriate ends of acute lobes 1-2(-3) cells long; terminal cell wall evenly slightly thickened at the apex. Lobe cells not or slightly elongate, at lobe bases (15-)20-40 $\mu \mathrm{m}$ wide, thin- to \pm thick-walled. Underleaves constantly present, patent, nearly as long as leaves, ovate, ovate-lanceolate or lanceolate, with obtuse to acuminate apex. Dioicous. Female bracts \pm entire. Perianth fleshy at the base, mouth crenulate-denticulate often bleached and destroyed. Spores ca. (9-)12-15(-16) $\mu \mathrm{m}$, echinate-punctate (SEM), from nearly as wide as elaters to about $2 \times$ as wide as elaters. Elaters occasionally partly 3-spiral.

Differentiation. Important distinctive characters of this species are total lacking of secondary pigmentation, regular large underleaves, frequent terminal and lateral intercalary branches, rare postical intercalary branches, lacking of stolons and antical leaf-free zone, concave \pm symmetric often \pm imbricate and subtransversely inserted leaves. Despite superficial similarity of C. albescens with not pigmented $C$. bicuspidata, C. albescens has much in common with $C$. pleniceps, namely in rather fleshy stem with mostly slightly differentiated hyalodermis, often broad leaves with evenly slightly thickened walls of terminal cells, shape of female bracts, fleshy perianth at the base, crenulate denticulate perianth mouth and structure of spore surface. Large underleaves and lateral intercalary branching distinguish this species from C. bicuspidata and C. pleniceps. C. albescens may be confused with mod. viridis of Odontoschisma francisci (Hook.) L. Söderstr. \& Ván̆a from which it differs in leaves with mostly acute lobes, regular and larger ovate or ovatelanceolate underleaves, oval not angulate gemmae.

Selected illustrations: Müller, 1951-1958: Fig. 169170; Schuster, 1974: Fig. 438-439; Schljakov, 1979: Fig. 22; Potemkin, 1993a: Fig. 2; Paton, 1999: Fig. 45; Damsholt, 2002: P1. 182.

World distribution. Circumpolar, Arctic, alpine and subalpine areas. In Europe recorded southward till Italy.

Distribution in Russia. From Arctic tundras to northern Taiga subzones, mountain tundras and mountain taiga and mountain deciduous coniferous forest.

Ecology. On acid to neutral soil (incl. peaty soil and soil over rocks). Often in late snow areas.

Selected specimens examined: RUSSIA: Murmansk Province: Lapponia ponojensis, VI.1872, Brotherus s.n. (LE); Arkhangelsk Province: Polar Urals, Mt. Jegenni Pai, reg alpi- 
na, 1905, R. Pohle s.n. (LE) (mod. laxifolia-grandiretis, postical intercal branch seen); Kamchatsky Territory: Kamchatka Peninsula, Vulcano Burlyashchiy, 6.VIII.2012 Neshataeva \#MT50 (LE) (fr., with partly 3-spiral elaters!); Sakhalin Province: Iturup Islands, vicinity of volcano of Baransky, in mixed forest, 23.IX.1974, Blagodatskikh s.n. (LE). SWEDEN: Torne Lappmark, Karesuande, the mountain of Peldsa, ca. 1000 m alt., 3.VIII.1939, Arnell s.n. (LE) (fr.); USA, Alaska, Seward Peninsula, at nival base of steep N-facing slope to Serpentine Creek, Potemkin \#92-067-02 (LE) (juv. caps.).

\section{Group IV Pachycaules (Cephalozia pachycaulis)}

Plants medium-size to rather large, whitish green, soft-textured. Branches postical intercalary, sporadically terminal Frullania-type, stolons unknown. Stem rather thick and soft of tender thin-walled cells, with vestigial hyalodermis of a locally larger cells than medullary cells, antical leaf-free zone (1-)2(-3) cells broad, antical cortical cells about as broad as basal leaf cells. Leaves much broader than stem, about as wide as long, moderately constricted at base, with transversely inserted antical leaf base and oblique succubously inserted postical leaf base, undecurrent, concave, nearly symmetrically $0.5-0.6-b i-$ lobed, postical half of leaf often larger than antical, with narrowly triangular, mostly straight, long acuminate to short ciliate lobes with terminal cell wall slightly thickened at apex. Underleaves lacking on sterile shoots.

Cephalozia pachycaulis R.M. Schust., 1993. Bryologist 96: 623. - Pleurocladula pachycaulis (R.M. Schust.) Konstant., Vilnet \& Troitsky, 2012. Arctoa 21: 125. - Fuscocephaloziopsis pachycaulis (R.M. Schust.) Váňa \& L. Söderstr., 2013. Phytotaxa 112(1): 11. — Fig. 2.

Plants medium-size to rather large, whitish green, softtextured. Branches postical intercalary, sporadically terminal Frullania-type, stolons unknown. Stem soft of tender thin-walled cells, with vestigial hyalodermis of a locally larger cells than medullary cells, antical cortical cells slightly elongate, ca. (27-)32-54×(30-)50-67(-90) $\mu \mathrm{m}$, antical leaf-free zone (1-)2(-3) cells wide. Rhizoids sometimes with branched ends. Leaves quadrate orbicular to broadly ovate suborbicular, \pm symmetric, mostly \pm concave, undecurrent, maximal leaf width in the lower third mostly; sinus often \pm rounded at base, mostly V-like, $0.5-$ 0.6 leaf-length; lobes narrowly triangular, mostly straight, long acuminate to short ciliate. Leaf cells very thin-walled, ca. $25-50 \times 30-55 \mu \mathrm{m}$ at base of lobes. Uniseriate ends of lobes of (1-)2-3(-4) elongate cells, terminal cell wall \pm slightly thickened at the apex. Dioicous. Female bracts entire, sinus ca. 0.4-0.5 their length. Perianth mouth shallowly lobulate; lobules with crenulate-denticulate or sporadically ciliate margins, with cilia of 1-2 strongly elongate cells. Spores not seen, ca. 9.5-10 $\mu \mathrm{m}, \pm$ vermiculate (LM), almost $1.5 \times$ as wide as elaters.

Differentiation. Cephalozia pachycaulis resembles plants of $C$. bicuspidata with acuminate lobe ends. It is easily distinguished due to distinct antical leaf-free zone
(1-)2(-3) cells wide, hardly differentiated hyalodermis of mature stems, acuminate-ciliate lobe ends formed of (1)2-3(-4) cells. It differs from rare xylicolous modifications of $C$. bicuspidata with acuminate-ciliate lobes in distinct antical leaf-free zone and fleshier stem without definite hyalodermis.

Selected illustrations: Schuster, 1993: Fig. 1, 2; Konstantinova et al., 2004: Fig. 1.

World distribution. USA: Alaska; Russia.

Distribution in Russia. Republic Sakha/Yakutia, Kamchatka Peninsula, Buryatia (Khamar-Daban Range), Kuril Islands (Bakalin et al., 2009).

Ecology. On \pm acid mineral soil and rocks in mountain tundra and more rare in taiga communities.

Selected specimens examined: RUSSIA: Republic of Buryatia: Khamar-Daban Range, Konstantinova \#117-01 (KPABG); Kamchatsky Territory: Kamchatka Peninsula, Bakalin \#74-501-VB (KPABG); 12.IX.1989, Chernyagina s.n. (LE); Republic Sakha/Yakutia: Tokinskyi Stanovik Range, tundra belt, on soil of stream bank in the mountain kar, Sofronova \#TC-00117 (SASY) (gem.). USA: Alaska, Konstantinova \& Schuster \#114-1-92 (KPABG). Detailed list of examined speciemens published in Konstantinova et al. (2004).

Group V Cephalozia (C. ambigua, C. bicuspidata, C. hamatiloba)

Plants medium-size to minute and rather large, whitish green to fuscous brown, purplish brown, deep purple, violetish and violetish black in sun lighted habitats. Branches postical intercalary and terminal Frullania-type, stolons present. Stem with distinct hyalodermis of thin- to moderately thick-walled cells, medulla of thin to moderately thick-walled cells, without antical leaffree zone, antical cortical cells as broad or much broader than basal leaf cells. Leaves when mature much broader than stem, about as wide as long or longer than wide, somewhat constricted at base, antical leaf base or only antical margin subtransversely inserted, undecurrent, postical - oblique succubously inserted, concave to nearly plane, rather symmetrically (0.3-)0.4-0.75(-0.8)-bilobed, postical half of leaf often slightly larger than antical, lobes \pm triangular acute to acuminate with terminal cell wall hardly to distinctly thickened at apex. Underleaves usually lacking on sterile shoots.

Cephalozia ambigua C. Massal., 1907. Malpighia 21: 310. - C. bicuspidata subsp. ambigua (C. Massal.) R.M. Schust., 1974. Hep. Anth. N. Amer. 3: 723. - Fig. 2.

Plants minute to medium-size whitish green to purplish brown and fuscous. Branches postical intercalary, terminal Frullania-type, stolons sometimes present. Stem with distinct hyalodermis of thin- to moderately thickwalled cells, medulla of thin- to moderately thick-walled cells, without antical leaf-free zone. Rhizoids with slightly swollen or hardly branched ends. Leaves broadly ovate to oblong-ovate, concave, undecurrent - base of antical margin \pm transversely inserted; maximal leaf width near the middle or between the middle and lower thirds, sinus 
\pm U- or V-like, (0.3-)0.4-0.5(-0.6) leaf length; lobes acute or very rare obtuse to rounded, straight. Uniseriate ends of acute lobes 1-2 cells long; terminal cell wall \pm stronger thickened at apex. Lobe cells often not or slightly elongate, at lobe bases (15-)17-30 $\mu \mathrm{m}$ wide, thin- to \pm thick-walled. Autoicous. Fertile plants not seen. Female bracts \pm entire, bilobed for $0.3-0.5$ their length. Perianth mouth crenulate-denticulate, with teeth at most of 1 cell, to subentire. Spores not seen, from 11-12 $\mu \mathrm{m}$ (Damsholt, 2002) to 13-16 $\mu \mathrm{m}$ (Müller, 1951-1958), verruculose (LM), about $1.5 \times$ as wide as elaters.

Differentiation. Cephalozia ambigua is rather rare arctic-alpine species. It is distinct from $C$. bicuspidata in mostly shallower sinus, (0.3-)0.4-0.5(-0.6) the leaf length, rare obtuse to rounded lobes, smaller size of cells, which are not or slightly elongate at the lobes, crenulatedenticulate perianth mouth. These characters, besides rare shallower sinus and rounded lobes illustrated by K. Müller (1951-1958: Fig. 403), overlap with those of extreme arctic-alpine phases of $C$. bicuspidata and cause their confusion. Schljakov (1979: 101) has mentioned also that unbranched shoots of $C$. ambigua keep straight position on the slide. Its antical surface is easily observed whereas those of $C$. bicuspidata usually fall on one side making lateral surface visible.

C. ambigua shares with $C$. hamatiloba often shallower sinus (common in plants known as $C$. otaruensis var. acrogyna) but distinct in sex distribution, mostly smaller cells and distribution pattern mainly. As it was shown by Koźlicka (1981) and Szweykowski (1984) some alpine forms of C. bicuspidata from Tatry Mts. with $\mathrm{n}=$ 27 may be indistinguishable from $C$. ambigua $(\mathrm{n}=9)$.

Selected illustrations: Müller, 1951-1958: Fig. 403; Schuster, 1974: Fig. 446: 6-9; 448: 4-11; Schljakov, 1979: Fig. 24: 1, 25: 1; Paton, 1999: Fig. 32; Damsholt, 2002: P1. 185.

World distribution. Circumpolar, Arctic, alpine and subalpine areas. In Europe southward till French Pyrenees and, according to J. Váňa (pers. com.), till Spain and Bulgaria.

Distribution in Russia. Arctic and adjacent mountain territories, South Siberia.

Ecology. From southern Polar Deserts to northern Taiga, mountain tundras and elfin wood areas in the Far East. On acid to neutral soil (incl. peaty soil and soil over the rocks).

Selected specimens examined: RUSSIA: Murmansk Province: Khibiny Mountain Massiv, near river bank on wet place, 30.VII.1966, Schljakov s.n. (LE) (mod. laxifolia-viridis, shoots to $0.6(0.75) \mathrm{mm}$ broad, with rather frequent Frullania-type branching and occasional obtuse leaf lobes); Chita Province: Sokhondiskiy Biosphere Reserve, Upper Bukukun River, stony bed of the river, in niche between stones, $1888 \mathrm{~m}$ alt., 21.VIII.2011, Mamontov s.n. (LE); Chukotka Autonomous District: Vrangel Island, 21.VII.1985 and 29.VII.1985, Afonina s.n. (LE). SWEDEN: Jemtland, Klöfsjö Skaland, 15.VIII.1907, Grape s.n. (LE); Torne Lappmark, Abiskojokk, 20.VII.1944,
Arnell s.n. (LE); USA, Alaska, Seward Peninsula, Potemkin \#92-115-01, 938104 (ALA, LE).

Cephalozia bicuspidata (L.) Dumort., 1835. Recueil Observ. Jungerm.: 18. - Jungermannia bicuspidata L., 1753. Sp. P1.: 1132. - C. lammersiana (Huebener) Spruce, 1882. On Cephalozia: 43. - C. bicuspidata var. lammersiana (Huebener) Breidl. 1893. Mitt. Naturwiss. Vereines Steiermark 1893: 329. - C. bicuspidata subsp. lammersiana (Huebener) R.M. Schust., 1974. Hep. Ant. N. Amer. 3: 730. — Figs. 2, 6: 1.

Plants medium-size to minute, whitish green to purplish brown, fuscous and deep purple in Arctic. Branches postical intercalary, terminal Frullania-type, stolons sometimes present. Stem with distinct hyalodermis of thin- to moderately thick-walled cells, medulla of thinto moderately thick-walled cells, without antical leaf-free zone. Antical leaf-free zone appears to be \pm obvious in plants of mod. laxifolia, in which lowermost parts of antical leaf margins originate from neighbour cell rows. Rhizoids with slightly swollen or hardly branched ends. Leaves broadly ovate to oblong-ovate and subrectangular, usually concave, undecurrent - base of antical margin \pm transversely inserted; maximal leaf width near the middle or between the middle and lower thirds, sinus mostly V- or U-like, 0.5-0.6 leaf-length; lobes acuminate to acute, rare ciliate, straight. Uniseriate ends of lobes 1-2(-3) cells long, terminal cell wall \pm stronger thickened at the apex. Lobe cells often elongate, at the lobe bases (20-)22-40 $\mu$ m wide. Autoicous. Female bracts \pm entire or in not known from Russia var. lammersiana (Huebener) Breidl. f. serraifolia Schiffn. \pm dentate (see Damsholt, 2002: Pl.184, 1, 5), sinus ca. 0.4-0.5 the length. Perianth mouth crenulate-denticulate to short dentate with teeth of 1-2 cells, as an exception laciniate-ciliate with teeth and cilia $2-5$ cells long. Spores ca. $12-15(-16) \mu \mathrm{m}$, densely thickly vermiculate to incompletely reticulate (SEM), about $1.5 \times$ as wide as elaters.

Differentiation. Cephalozia bicuspidata is an extremely malleable species having minute and rather robust, colourless and intensively pigmented, slender and fleshy phases. It may be confused with $C$. ambigua, $C$. hamatiloba, C. lacinulata and C. macounii mostly. Its xylicolous mod. parvifolia-laxifolia-angustifolia may be confused with $C$. lacinulata. Such plants of C. bicuspidata, however, are sterile and have narrow leaves with bases of antical margins of opposite neighbour leaves originating from neighbour antical cell rows of hyalodermis and subtransversely inserted. Similar plants of C. lacinulata are usually fertile, have leaves with longitudinally inserted antical margin and distinct antical leaffree zone (Fig. 3). C. bicuspidata is distinct from typical C. hamatiloba (except C. dubia and C. otaruensis var. setiloba phenotypes) in autoicous sex distribution, deeper (0.5-0.65 vs. $0.4-0.5)$ sinus of leaves with maximal width between their middle and lower thirds, rather straight vs. evenly rounded lateral leaf margins of nar- 
row leaves, and much broader distribution pattern. Thin stems may be with 5 rows of large inflated outer cells and 5 rows of minute inner cells in 2 layers. Lobe apices usually 1-2-celled. In some xylicolous plants, however, they may be of 2-3 elongate cells. Perianth mouth varies from crenulate to short dentate with 1-2 celled teeth to setulose and nearly laciniate-ciliate with cilia 3-5 cells long as was mentioned in Potemkin, Kotkova Ц-30 (cf.: Paton, 1999: Fig. 31). Development of such perianth mouth may correlate with formation of $2-3$ celled acuminate leaf lobes, \pm evenly thick-walled cells of leaves, thickened wall at the apices of leaf lobes. These characters are an adaptation for growth on rotten wood in conditions of unstable air and/or rotten wood humidity. Similar perianth mouth is characteristic of $C$. hamatiloba as well. Such modifications of C. bicuspidata differ from C. hamatiloba in invariably deeper sinus, often acuminate-ciliate leaf lobes with uniseriate ends of 2-3 elongate cells. Plants of mod. parvifolia-angustifolia-laxifolia of C. bicuspidata may be confused with similar modifications of $C$. hamatiloba. They are distinct in leaves with mostly \pm straight to slightly and unevenly convex (vs. evenly convex) margins and maximal width between the middle and lower thirds (vs. near the middle or a little below).

Cephalozia bicuspidata s. 1. was treated by Schuster (1974) as a single malleable species with four subspecies [subsp. ambigua (here C. ambigua), subsp. austrigena (C. austrigena), subsp. bicuspidata, subsp. otaruensis (here C. hamatiloba)]. Such an approach is resulted from considerable overlap of variability of these species, which was studied and described by Koźlicka (1981) and treated also by Szweykowski (1984: 1155). At present it is distinguished as a group of closely related species with considerable overlap of variability ranges $-C$. ambigua $(\mathrm{n}=9), C$. bicuspidata $(\mathrm{n}=18,27$ - var. lammersiana $)$, C. hamatiloba $(\mathrm{n}=9-$ C. otaruensis and $\mathrm{n}=18$ C. hamatiloba). This causes problems of their identification, which are not solved yet.

Selected illustrations: Schuster, 1974: Figs. 446: 15, 447, 448: 1-3; Schljakov, 1979: Figs. 23: 1, 24: 2; 25 : 2, 26; Paton, 1999: Fig. 31; Damsholt, 2002: Pl. 183, 184; Atherton et al., 2010: 93-94.

World distribution. Mostly northern and temperate Eurasia (not known in Asia southward of Taiwan), Azores, North America, northern South America, Macaronesia, Africa (central African mountains, South Africa). The species was also recorded for remote islands of southern Indian (Reunion, Marion I., Crozet Is.) and Atlantic (Tristan da Cunha group) oceans, Chili, South Georgia, Tasmania (Schuster, 1974; Piippo, 1990; Váňa, 1993; Damsholt 2002). However, recently circumscribed as a separate species C. austrigena R.M. Schust. ex J. J. Engel based on $C$. bicuspidata subsp. austrigena R.M. Schust., nom. inval. is known from New Zealand only (Engel, 2007). The other antipodal records of C. bicuspidata need to be checked for C. austrigena.
Distribution in Russia. Most widespread species of the genus in Russia, recorded from Polar Deserts to Deciduous Forest Zone, occurs also in mountain taiga, mountain deciduous-coniferous forests and mountain tundras.

Ecology. On acid and occasionally \pm neutral substrata - bare soil, rocks, rotten wood, among mosses and among Sphagnum, particularly, at bases of trees.

Selected specimens examined: RUSSIA: Leningrad Province, Bol'shaya Izhora Settlement, on rotten wood, 27.VII.1984, on soil near water, 14.VIII.1984, on path in forest, on soil, 1.VIII.1984, all Potemkin s.n. (LE); Tver' Province: Central Forest State Biosphere Reserve, swampy spruce forest with admixture of small-leaved trees, on rotten ?pine stump, Potemkin \& Kotkova \#Ц-30 (LE) (a form with setulose to laciniate-ciliate perianth mouth and 2-3-celled lobe ends); Orel Province: on pine log, Kotkova \#OP-09-95 (LE) (per., mod. densifolia-viridis - xylicolous form with distinctly thickened cell walls at lobe apices); Yamalo-Nenetsky Autonomous District: Yamal Peninsula, Mys Kamenny Village, lichen-herb-moss tundra on gentle slope, 31.VII.1988, Potemkin s.n. (LE) (per., gem.); Republic Sakha/Yakutia: Orulgan Range, swamp, on soil, 19.VI.2006, Sofronova s.n. (SASY); Chukotskij Autonomous District: Ion Island, sedge-moss mire, 23.VII.1983, O.M. Afonina s.n. (LE).

Cephalozia hamatiloba Steph., 1908. Bull. Herb. Boissier, sér. 2, 8: 427. - C. otaruensis Steph., 1924. Sp. Hepat. 6: 434. - C. bicuspidata subsp. otaruensis (Steph.) S. Hatt., 1959. J. Hattori Bot. Lab. 21: 95. - C. dubia S. Hatt., 1944. Bull. Tokyo Sci. Mus. 11: 72, Fig. 44. - C. lammersiana (Huebener) Carrington var. innovata Amakawa, 1952. J. Hattori Bot. Lab. 7: 70, Fig. 1. - C. otaruensis var. acrogyna Amakawa, 1952. J. Hattori Bot. Lab. 7: 73, Figs. 3, 4. - C. otaruensis var. setiloba (Steph.) Amakawa, 1952. J. Hattori Bot. Lab. 7: 74, Fig. 5. - Fig. 2.

Plants medium-size to minute and rather large, whitish green to violetish, violetish black, reddish brown or brown. Branches postical intercalary, terminal Frullania-type, stolons sometimes present. Stem with distinct hyalodermis of thin- to moderately thick-walled cells, medulla of thin- to moderately thick-walled cells, without antical leaf-free zone. Antical leaf-free zone appears to be \pm obvious in plants of mod. laxifolia, in which lowermost parts of antical leaf margins originate from neighbour cell rows. Rhizoids with slightly swollen or hardly branched ends. Leaves ovate to oval, concave or plane, undecurrent, with base of antical margin \pm transversely inserted, or short decurrent and oblique inserted in plants of mod. laxifolia, maximal leaf width between the middle and lower thirds or near the middle; sinus \pm acute and V-like to somewhat rounded at the base, $0.4-0.46(-0.5)$ leaf length in mod. latifolia to $0.55-0.75$ ($0.8)$ in mod. angustifolia; lobes straight, \pm acute, as an exception single lobes blunt. Cells at lobe bases ca. (20-)22$40 \mu \mathrm{m}$ wide. Uniseriate ends of lobes 1-2 cells long, terminal cell wall \pm stronger thickened at the apex. Dioicous. Female bracts entire or with a few teeth on outer margins, sinus $0.4-0.6$ the length. Perianth mouth lobulate dentate 
or ciliate, cilia of $1-5$ cells. Spores not seen, ca. 11-14 $\mu \mathrm{m}, \pm$ papillose (LM), a little wider than elaters.

Nomenclature note. Váňa (1988: 192) have suggested to consider $C$. otaruensis Steph. 1924 as a synonym of $C$. hamatiloba Steph. 1908. Both species are very similar morphologically but different in chromosome numbers ( $\mathrm{n}=9$ vs. $\mathrm{n}=18$ respectively). Despite they are still accepted by Japanese bryologists (Yamada \& Iwatsuki, 2006) we follow Váňa (1988), Long and Grolle (1990) and use name $C$. hamatiloba for plants previously named in Russian literature C. otaruensis. We distinguish it as a different chromosome race of $C$. hamatiloba.

Differentiation. Being similar to C. bicuspidata in habitus and extreme variability $C$. hamatiloba is distinct in different manifestation of its forms. Broad leaf forms illustrated as C. otaruensis var. acrogyna (Amakawa, 1952a: Figs. 3, 4) are distinct from broad-leaf forms of $C$. bicuspidata in shallower sinus, $0.4-0.46(-0.5)$ the leaf length. Narrow-leaf forms illustrated as C. otaruensis var. setiloba (Amakawa, 1952a: Fig. 5) and C. dubia (Hattori, 1944, Fig. 44) have leaves with evenly convex (vs. mostly \pm straight to slightly and unevenly convex) margins and sinus descending $0.55-0.75(-0.8)$ the leaf length.

This species might be misunderstood because of its well-known treatment by Schuster (1974) based on American materials from Southern Appalachian Mts. Plants from Appalachian Mts., however, differ from Japanese plants in smaller size even in moist conditions, more rigid structure, only postical intercalary branching and mostly crenulate perianth mouth with teeth free at the ends of marginal cells only. Schuster (1974: 736) has attributed these plants to $C$. bicuspidata subsp. otaruensis with hesitation. He wrote: "Until more copious American collections come to hand, a resolution of the problem where to place the present phenotype seems unobtainable".

Inoue (1974: 187) has advocated separate position of C. hamatiloba (as C. otaruensis) from C. bicuspidata on the basis of different chromosome number and sharp ciliate, with (2-)3-5-celled cilia, never denticulate perianth mouth. The perianth was illustrated by Inoue (1974: P1. 61: 1, 11) and looks different from that of C. bicuspidata. This description of perianth mouth of $C$. otaruensis corresponds to original description of perianth mouth by Stephani (1924: 434): "ore truncato plicato, dense longeque setuloso". However, study of some perianths in Hep. Jap. ser. (11) 65, 513 and H. Inoue: Bryophyta selecta exsiccata 204 has shown they have mouths with 1$2(-3)$-celled \pm remote spinous to finger-like teeth. Similar 1-2(-3)-celled teeth of perianth mouth were illustrated by Amakawa (1952a: Figs. 2: $L, M ; 5: I, J$ ). Occasional finds of $C$. bicuspidata with setulose to ciliate perianth mouth (Paton, 1999: Fig. 31; this treatment: Fig.: 1) make this character not much reliable. However, molecular study of the suborder Cephaloziineae by Vilnet et al. (2012) confirms separate position of C. hamatiloba (as C. otaruensis) from C. bicuspidata.
Selected illustrations: Hattori, 1944, Fig. 44; Amakawa, 1952a, Figs. 1 (as C. lammersiana var. innovata), 3 5; Inoue, 1974: P1. 61. Iwatsuki et al., 2001: P1. 132: 6.

World distribution. Pacific Asia (Russian Far East, Japan, Taiwan, Hinan Isl.), China (Hunan Prov., LE), eastern North America (Appalachian Mts.). C. hamatiloba subsp. siamensis (N. Kitag.) Váňa was reported from Bhutan, S. India and Thailand (records summarized in Long and Grolle (1990) under C. siamensis N. Kitag.).

Distribution in Russia. Far East from Chukotka to S. Kurils and Primorye Territory.

Ecology. The species recorded in Russia from soil, rocks and rotten wood in mountain tundras and occasionally in mountain taiga.

Selected specimens examined: RUSSIA: Chukotka Autonomous District: Chukotka Peninsula, Mys Yandogay, rocky mountain dwarf shrub-lichen tundra, on fine earth, 22.V.1978, Afonina s.n. (LE); Kamchatka Territory: Kamchatka Peninsula, Burlyashchiy Volcano, termal field, Neshataeva \#TП-3, Пp-1, K-4 (LE) (male and female plants with juv. per., per. mouth densely dentate-ciliate with 1-3 celled cilia/teeth of elongate cells); Primorsky Territory: Ussuriyskiy Reserve, Komarovka River Valley, Cedar-Deciduous forest, on rotten wood, 1.IX.1980, Gambaryan \#G104770 (KPABG 104770) (per., mod. angustifolia); Ussuriyskiy Reserve, Upper Artyomovka River, decidous forest, on rotten wood, Mamontov \#10/110 (LE) (mod. parvifolia-angustifolia). JAPAN: Kiushiu, Miyazaki, Mimaminaka, Sakatani, in ligno putrido, sciophila, ca. $500 \mathrm{~m}$ alt., XI.1946, Hattori \& Kurata s.n. (LE) (per.); Kyushu, Kumamoto Prefecture, Kuwamura near Hitoyoshi, on moist rocks, alt. ca. 100 m., 17.IX.1950, Mayebara s.n. (LE); Isl. Yakushima, on wetty granitic rocks, 800-900 m alt., 26.VII.1956, Amakawa s.n. (LE) (male plants); Kyushu, Kumamoto Prefecture, near Hitoyoshi, on wet rocks in stream, 28.X.1951, Mayebara s.n. (LE) (per.); Honshu, Nagano Prefecture, Natsuzawa pass, on wet agglomerate along stream, ca. $2100 \mathrm{~m}$ alt., 14.VII.1952, Shimizu s.n. (LE) (per.); Honshu, Tochigi Prefecture, near summit of Mt. Nasu, on wet soil, about $1900 \mathrm{~m}$ alt., 18.VI.1969, Inoue s.n. (LE) (fr., a form close to C. bicuspidata, mod. fusca); CHINA: Hunan Province, broad leaved forest, subtropical (warm temperate) zone, partial shade, moist, ridge, on top of rock, Koponen, Huttunen \& P.-C.Rao \#53372 (LE) (mod. laxifolia).

\section{Group VI Macouniae (Cephalozia macounii)}

Plants minute, whitish green, soft-textured. Branches postical intercalary, stolons lacking. Stem thin and rigid, hyalodermis and medulla of \pm thick-walled cells, antical leaf-free zone indistinct, antical cortical cells about as broad as basal leaf cells. Leaves about as wide as stem, considerably longer than wide, not constricted at base, subtransversely succubously inserted, undecurrent, slightly concave, nearly symmetrically $0.55-0.8$-bilobed, postical half of leaf subequal or larger than antical, lobes narrowly triangular-lanceolate to nearly spinous, 2-4(6) cells broad at the base, with 2-3-celled uniseriate end of \pm elongate cells, terminal cell wall strongly thickened at apex. Underleaves lacking on sterile shoots.

Cephalozia macounii (Austin) Spruce, 1882. On Cephalozia: 68. - Jungermannia macounii Austin, 1869 [1870]. Proc. Acad. Nat. Sci. Philadelphia 21: 222 . Figs. 2, 6: 2, 8: 4. 
Plants minute, tender and never pellucid, often Cephaloziella-like, without secondary pigmentation, shoots 0.12-0.2(-0.35) mm wide. Branches postical intercalary, stolons lacking. Stem thin, (35-)45-60(-85) $\mu \mathrm{m}$ wide, with superficially indistinct hyalodermis and medulla of \pm thickwalled cells, antical leaf-free zone indistinct, antical cortical cells ca. $12-17 \times 20-30 \mu \mathrm{m}$. Rhizoids with slightly swollen ends. Leaves on sterile shoots usually contiguous or sometimes \pm distant, mostly conceal the stem, inserted nearly transversely or at considerable angle to the stem, undecurrent, \pm ovate-rectangular, slightly concave, sinus V-like, 0.55-0.8 leaf length. Lobes not connivent, straight, narrowly triangular-lanceolate to nearly spinous, 2-4(-6) cells broad at base, with 2-3-celled uniseriate end of \pm elongate cells. Cells at base of lobes \pm thick-walled, ca. 12 $19 \times 15-20(-23) \mu \mathrm{m}$. Terminal cell wall of lobes distinctly thickened at the apex. Dioicous. Female bracts \pm spinose dentate, sinus $0.5-0.7$ their length. Perianth mouth \pm dentate to setulose with teeth 1-2 cells long. Spores ca. 7.5$10 \mu \mathrm{m}$, densely thickly vermiculate- to reticulate-punctate (SEM), about $1.5 \times$ as wide as elaters.

Differentiation. This obligate xylicolous species occurs on decaying logs in densely shaded primeval forests with high continuous humidity. It is distinguished due to minute size of plants $0.12-0.2(-0.35) \mathrm{mm}$ wide, narrow deep-bilobed (0.55-0.8 leaf length) and not scale-like leaves, which usually \pm subimbricate and conceal thin stem (35-)45-70(-85) $\mu \mathrm{m}$ wide, female bracts with \pm dentate margins and sinus $0.5-0.7$ the length. These characters as well as indistinct antical leaf-free zone differentiate $C$. macounii from $C$. leucantha having remote and shallower bilobed leaves (0.35-0.65 leaf-length), which do not conceal the stem, shorter leaf lobes of subisodiametric (vs. elongate) cells with entire (vs. often subdentate) margins and entire female bracts with shallower sinus, $0.3-0.6$ the length. Moreover C.macounii has antical cortical cells about as wide as basal leaf cells whereas in C. leucantha they are much broader than basal leaf cells.

Cephalozia macounii may be confused with species of Cephaloziella and mod. parvifolia-angustifolia-densifolia of $C$. catenulata, from which it differs in deeper sinus, narrower leaves and lobes as well as nearly transverse leaf insertion. For details see comments for $C$. catenulata. Considerably larger outer than inner cells of stem differ sterile plants of C. macounii from species of Cephaloziella. Juvenile plants of mod. parvifolia-angustifolia-densifolia of $C$. bicuspidata have much in common with $C$. macounii when studied with hand-lens. They are distinct in larger and more thin-walled cells of leaves.

Selected illustrations: Müller, 1951-1958: Fig. 419; Schuster, 1974: Fig. 454; Schljakov, 1979: Рис. 33; Damsholt, 2002: P1. 189.

World distribution. Very rare North Holarctic, probably circumboreal \pm transcontinental in Eurasia and North America, until present unknown from Russian Far East and, according to Ván̆a from nearly all European countries except Sweden, Finland and Latvia, records from Poland and Montenegro probably erroneous (Váňa, pers. com., 2013). The records listed earlier in Duell (1983) and Damsholt (2002) were not confirmed by Schumacker and Váňa (2005).

Distribution in Russia. Rare in taiga and mountain taiga in European Russia, West and South Siberia. Record of this species from Putorana Plateau (Zhukova, 1986) cited by Konstantinova, Bakalin et al. (2009) is doubtful because of not characteristic habitat: on soil among mosses and liverworts in sparse larch forest with dwarf birch. The specimen is lost.

Ecology. Restricted to decaying wood in deep shade and high humidity conditions in old-growth taiga forests.

Selected specimens examined: RUSSIA: Republic of Karelia: old growth coniferous forest ... on rotten wood, Potemkin \& Kotkova \#321601 (LE); Republic of Komi: Pechoro-Ilychsky Reserve, moss spruce forest near spring, on rotten wood ..., Dulin \#154МВД (LE) (per., fr.); Perm Territory: Vishersky Reserve, blueberry moss forest, on rotten wood, Bezgodov \#A5206a-94 (KPABG 106328) (female plants with unfertilized gynoecia); Kemerovo Province: Kuznetskiy Alatau, Middle Kia River, abies fern-tall herb forest, on lateral sides of strongly rotten stump, Konstantinova \#18-4a-00 (KPABG-101796); Republic of Buryatia: KhamarDaban Range, vicinity of Tankhoy Settlement, Lower Osinovka River, mixed herb forest, on old rotten wood, in shade, admixture to C. lacinulata, 6.VII.1990, Kazanovsky s.n. (LE, dupla ex IRK). FINLAND: North Karelian Biosphere Reserve, Hattuvaara Municipality, Raiskionaho, moss-Myrtillus spruce forest, on rotten wood, Maksimov \#11-337 (LE); S. Piippo: Hepaticae exs. S.O. Lindbergii 186. Regio abojensis: Lojo, "Ojamo" single shoot among Cephalozia “affinis", 2.VII.1877, Lindberg (LE).

\section{Group VII Pleniceps (Cephalozia pleniceps)}

Plants medium-size, green, or whitish green. Branches postical intercalary, terminal Frullania-type branches and stolons sometimes present. Stem on antical side with slightly to sharply defined hyalodermis of thin- to slightly thick-walled cells, medullary cells of thin to moderately thick-walled cells; antical leaf-free zone (1-)2(-3) cells wide. Leaves broader than stem, about as wide as long, constricted at postical base, concave to nearly plane, antical leaf base or only antical margin subtransversely inserted, 0.35-0.5-bilobed, postical half of leaf often larger than antical, lobes \pm triangular acute to blunt with terminal cell wall not stronger thickened at apex. Underleaves usually lacking on sterile shoots, in xeromorphic plants sometimes present near apex, subulate.

Cephalozia pleniceps (Austin) Lindb., 1883. Meddeland. Soc. Fauna Fl. Fenn. 9: 158. — Jungermannia pleniceps Austin, 1869 [1870]. Proc. Acad. Nat. Sci. Philadelphia 21: 222. - C. pleniceps var. caucasica Duda, 1962. Бот. матер. отд. спор. раст. [Botanicheskie Materialy Otdela Sporovykh Rasteniy] 15: 163. — Pleurocladula pleniceps (Austin) Konstant., Vilnet et Troitsky, 2012. Arctoa 21: 125. - Fuscocephaloziopsis pleniceps (Austin) Váňa et L. Söderstr., 2013. Phytotaxa 112(1): 11. - Figs. 4, 5: 3, 4, 8: 1 . 
Plants medium-size, whitish green, without secondary pigmentation, plants of mod. densifolia often fleshy. Branches postical intercalary, terminal Frullania-type branches and stolons sometimes present. Stem with distinct hyalodermis at least on antical surface, medullary cells with hardly to considerably thickened walls. Antical cortical cells variable, from subisodiametric to distinctly elongate, ca. (25-)35-50(-75)×40-90(-125-150) $\mu \mathrm{m}$, antical leaf-free zone is distinct or rather indistinct, 1-3 cells wide. Rhizoids often with swollen ends. Leaves \pm concave to plane in mod. laxifolia with stronger convex postical margin, hardly to distinctly decurrent — base of antical margin oblique to subtransversely inserted, maximal leaf width mostly near the middle, sometimes between the middle and lower thirds; sinus obtuse $\pm \mathrm{U}$ or V-like, 0.35-0.5 leaf-length; lobes terminated by blunt to \pm acute terminal cell as a rule with not stronger thickened wall at the apex, not or slightly connivent. Cells large, at base of lobes variable, sometimes even from one leaf to another (var. caucasica), 20-60×24-56(-80) $\mu \mathrm{m}$. Uniseriate ends of lobes 1-2 cells long, (23-)35-55(-65) $\mu \mathrm{m}$ at the base. Underleaves lacking or in xeromorphic f. concinnata (Müll. Frib.) Damsh. frequently present at shoot apex, subulate (Damsholt, 2002). Autoicous. Female bracts \pm entire, sinus $0.4-0.6$ the length. Perianth mouth crenulate-denticulate with teeth of cell projections mostly. Spores ca. (11-)12-16.5(-21) $\mu \mathrm{m}$ with indistinct areolation \pm densely thickly reticulate-punctate (SEM), about $2 \times$ as wide as elaters.

Differentiation. An extremely variable species with broad ecological amplitude. It might be confused with C. affinis, C. lunulifolia, C. connivens and C. pachycaulis. C. pleniceps is usually distinct because of rather robust size, fleshy habit and often \pm concave leaves without stronger thickening at the apex walls of terminal lobe cells. It is easily distinct from the other species of the genus by inability to produce thickening of terminal lobe cell apex, in larger cells, sporadic terminal branches and stolons. These characters as well as crenulate to shallowly lobulate crenulate-denticulate perianth mouth and bracts with entire margins serve also to differentiate $C$. pleniceps from $C$. connivens having also large cells (see comment for C. connivens). It is distinct from C. affinis, C. lunulifolia and $C$. connivens in normally oblique to subtransverse insertion of antical leaf base, larger leaf cell size, width of uniseriate end of lobe base, particularly. C. pleniceps never develops long acuminate-ciliate lobe ends like $C$. pachycaulis. It is noteworthy that in Arctic on exposed bare soil C. pleniceps sometimes develop minute fleshy phases, $1.5-4 \mathrm{~mm}$ long only, with perianths 4-5-stratose at the base and unistratose in the upper half only (Potemkin, 1993b). Similar form is known from Europe as C. pleniceps f. concinnata (Müll. Frib.) Damsh. (Damsholt, 2002). Important distinctive character of $C$. pleniceps from C. affinis is larger spores, (11-) 12-16(-21) $\mu \mathrm{m}$.
Described from the Nothern Caucasus C.pleniceps var. caucasica is of doubtful variety rank. Mentioned in original description variability of leaf cell size (Abramova, Duda, 1962) was not distinguished in studied material. The only marked distinction of plants from Caucasus is locally indistinct antical leaf-free zone, which, however is rather variable in this species. Morphological variability of this species was supported by its considerable genetic variability mentioned by Vilnet et al. (2012). Structure of spore surface in materials from Yamal Peninsula and Central Caucasus have much in common and are distinct in density of projections (Figs. 5: 3, 4).

Selected illustrations: Müller, 1951-1958: Fig. 407; Schuster, 1974: Fig. 445: 7-8, 456, 457; Schljakov, 1979: Pис. 27: 1; Paton, 1999 : Fig. 38; Damsholt, 2002: Pl. 191.

World distribution. Circumboreal, more common in Arctic.

Distribution in Russia. Widespread but infrequent in boreal plant communities; from polar deserts to subtaiga, from mountain tundras to mountain deciduous coniferous forests.

Ecology. In temperate-boreal region occurs in swampy sites among Sphagnum and other mosses, on rotten wood, soil, and rocks. Prefers subneutral to basic substrata in Arctic.The only considered species of the genus with marked tolerance to calcareous condition. In Arctic it is the only frequent species of Cephalozia in basic sites (Schuster, 1974: 774).

Selected specimens examined: RUSSIA: St. Petersburg Territory: vicinity of town of Sestroretsk, Glukhoe Lake, among Sphagnum and on rotten wood, 4.X.2012, 23.VIII.2013, Potemkin s.n. (LE) (per.); Novgorod Province: Khvoyninsky District, ... in depression among Sphagnum, Potemkin \#70612-3 (LE); Tver Province: ... on wet bare soil of forest path ..., Potemkin \& Kotkova \#L-19 (.)243 (LE) (per.); Republic of Kabardino-Balkariya, Mt. Cheget, subalpine belt, on partly shaded wet soil on rocky slope, Kotkova \#479 (LE) (fr.); Republic of Karachaevo-Cherkessia: ... along tussock margins and in depression between tussocks in mesotrophic part of mire in Teberda River flood plain, 11.VIII.1955, Abramovs s.n. (LE) (per.); Yamalo-Nenetsky Autonomous District: Yamal Peninsula, Khuty-yaha River Basin, moss tussock tundra, 26.VII.1977, Andrejeva s.n. (LE) (mod. grandiretis); Er'yaha River Basin, ... 12.VIII.1978, Andrejeva s.n. (LE) (fr.); Central Yamal, Neromoyakha River Basin, in nival willow stand near slope on bare soil with $C$. bicuspidata (Cephalozia connivens auct. non (Dicks.) Lindb. - Potemkin, 1993b), 20.VII.1990, Rebristaya s.n. (LE); Polar Urals, Middle Sob’ River... bottom of wet ditch, 1988 Czernyadjeva № 64 (LE); Republic Sakha/Yakutia: Orulgan Range, among Sphagnum, 30.VI.2006, Sofronova s.n. (SASY). FINLAND: Regio aboensis: "Lojo, ad truncum Piceae abietis valde cariosum loco umbroso et humido paludis sphagnosi prope Paloniemi", 23.VI.1885, Lindberg s.n. (LE) (fr., spores 12.5-15 $\mu \mathrm{m}$, terminal lobe cells with not thickened apical wall).

Group VIII Obscurae (Species of sections Catenulatae, Lacinulatae and Lunulifoliae)

Plants medium-size, green, whitish green or brown. Branches postical intercalary, stolons lacking or some- 
times present in $C$. loitlesbergeri only. Stem on antical side with sharply defined hyalodermis of thin- to moderately thick-walled cells, medullary cells moderately to strongly thick-walled; antical leaf-free zone 2 cells wide, antical cortical cells about $1-1.5 \times$ as broad as basal leaf cells. Leaves broader than stem, about as wide as long, constricted at base at least on postical side, concave to nearly plane, antical leaf base or only antical margin longitudinally inserted, decurrent or not, (0.25-)0.3-0.65($0.8)$-bilobed, postical half of leaf often larger than antical, lobes \pm triangular acute to blunt with terminal cell wall stronger thickened at apex. Underleaves lacking on sterile shoots.

Cephalozia affinis Lindb. ex Steph., 1908. Sp. Hepat. 3: 291. - C. affinis Lindb., 1883. Meddeland. Soc. Fauna Fl. Fenn. 9: 158 [nomen nudum]. — Pleurocladula affinis (Lindb. ex Steph.) Konstant., Vilnet \& Troitsky - Fuscocephaloziopsis affinis (Lindb. ex Steph.) Váňa \& L. Söderstr., 2013. Phytotaxa 112(1): 9. — Figs. 4, 5: 1 .

Plants medium-size whitish green, without secondary pigmentation. Branches postical intercalary, stolons lacking. Stem with distinct hyalodermis; cells of antical surface of stem ca. $25-40(-50) \times 35-60(-100) \mu \mathrm{m}$; medullary cells \pm thick-walled, antical leaf-free zone distinct. Rhizoids often with branched ends. Leaves ovate-orbicular, plane, \pm distinctly decurrent - base of antical margin inserted along the stem; maximal leaf width near the middle, postical margin stronger convex than antical margin or similarly convex; sinus \pm U-like, ca. (0.25)0.3-0.4(-0.5) leaf length; lobes acute, not or slightly connivent. Uniseriate ends of lobes 1-2 cells long, (25)30-37(-40) $\mu \mathrm{m}$ wide at the base, terminal cell wall \pm stronger thickened at the apex. Cells at base of lobes 20$35(-37) \times 25-35(-40) \mu \mathrm{m}, \pm$ thin-walled. Underleaves lacking. Autoicous. Male branches minute spicate, close to female, often soon decaying. Female bracts \pm entire. Perianth mouth \pm lobulate-dentate or lobulate-ciliate, with teeth or cilia $2-3$ cells long. Spores ca. 8-10 $\mu \mathrm{m}$, thickly reticulate- (meshes ca. $0.8-1 \mu \mathrm{m}$ ) to vermiculate-punctate (SEM), about $1.5 \times$ as wide as elaters.

Differentiation. A critical species, which distribution still remains unclear. Having much in common with C. lunulifolia it might be certainly distinguished from the latter when autoicous sex distribution is certainly defined. The other distinctive characters are less stable (cf. Schuster, 1974; Damsholt, 2002) and may be taken into account when occur together: mostly lobulate-ciliate perianth mouth (vs. crenulate to shallowly lobulate-dentate), mostly broader basal cells of uniseriate lobe ends [(25-)30-37(-40) at the base vs. 20-33(-35) $\mu \mathrm{m}]$ and often more symmetric and less decurrent leaves. It is very easy to misidentify sex distribution in C. affinis because of decay of minute male branches. Studied material with frequent and numerous sporophytes collected at the beginning of June in the Novgorod Region contains older plants which were fertil- ized apparently at autumn, passed the winter and began to die and decay after maturation of sporophytes. Their new innovations grow over such plants and hide them. This makes problematic to segregate such plants keeping male and female branches together.

Some phenotypes of $C$. affinis are similar to C. pleniceps. Distinctions of these species are listed below.

- Cell wall of uniseriate lobe ends mostly stronger thickened at the apex; uniseriate lobe ends (25-)30 $37(-40) \mu \mathrm{m}$ wide at the base; cells at base of lobes $20-35(-37) \times 25-35(-40) \mu \mathrm{m}$; cells of antical surface of stem $25-40(-50) \times 35-60(-100) \mu \mathrm{m}$; terminal branches and stolons lacking; perianth mouth lobulate-dentate or lobulate-ciliate, with teeth or cilia 2 3 cells long; spores ca. $8-10 \mu \mathrm{m}$, about $1.5 \times$ as wide as elaters. C. affinis

- Cell wall of uniseriate lobe ends evenly thickened at the apex; uniseriate ends of lobes (23-)35-55(-65) $\mu \mathrm{m}$ wide at the base; cells at base of lobes (25-)33$40(-50) \times 40-50(-55) \mu \mathrm{m}$; cells of antical surface of stem (30-)40-50(-75) ×(40-)50-100(-150) $\mu \mathrm{m}$ long; terminal branching and stolons sometimes present; perianth mouth crenulate to short dentate; spores (11-) $12.5-16.5(-21) \mu \mathrm{m}$, about $2 \times$ as wide as elaters .....

\section{C. pleniceps}

Selected illustrations: Mьller, 1951-1958: Fig. 415; Schuster, 1974: Fig. 459; Damsholt, 2002: Pl. 193.

World distribution. Poorly known because of impossibility for identification when sterile, probably circumboreal with range extensions in mountain deciduous and deciduous coniferous forest southwards.

Distribution in Russia. Taiga and Subtaiga zones. European and West Siberian Russia, North Caucasus. Records of this species from southern and mountain tundras of Polar Urals (Zinovjeva, 1973) need revision.

Ecology needs to be carefully investigated. Known records from Russia are from rotten wood. According to Schuster (1974) and Damsholt (2002) apparently with the same ecology and associates as $C$. lunulifolia.

Selected specimens examined: RUSSIA: Novgorod Province: ... on pine log at the edge of clearing, Potemkin \#70612-1 (LE) (fr., autoicous!); ... on spruce log, Potemkin \#30612-9 (LE) (fr., autoicous! - male branchlets very short); Yaroslavl Province: Darvinskiy Reserve, mire along Mshichinsky winter road, at the base of birch, on root, 14.VI.1990, Potemkin s.n. (LE) (fr., autoicous!); Tver Province: ... on rotten wood, Kotkova \#2408121 (LE) (per., autoicous!). FINLAND, North Karelian Biosphere Reserve, Syväjärvi, blueberry spruce forest near clearing, on pine log, Potemkin \& Lositskaya \#19704 (LE) (per., autoicous!).

Cephalozia catenulata (Huebener) Lindb., 1872. Contributio ad Floram Cryptogamam Asiae Boreali-Orientalis [Acta Soc. Sci. Fenn. 10]: 262. — Jungermannia catenulata Huebener, 1834. Hepaticologia Germanica: 169 Cephalozia nipponica S. Hatt. 1944. Bull. Tokyo Sci. Mus. 11: 74. - C. media Lindb. var. nipponica (S. Hatt.) Amakawa. 1952. J. Hattori Bot. Lab. 8: 56. - C. catenu- 
lata subsp. nipponica (S. Hatt.) Inoue. 1985. J. Hattori Bot. Lab. 60: 335. - Pleurocladula catenulata (Huebener) Konstant., Vilnet \& Troitsky, 2012. Arctoa 21: 125. Fuscocephaloziopsis catenulata (Huebener) Váňa \& L. Söderstr., 2013. Phytotaxa 112(1): 9. - F. catenulata subsp. nipponica (S. Hatt.) Váňa \& L. Söderstr., 2013. Phytotaxa 112(1): 9. - Figs. 3, 7: 2-4.

Plants minute to small, green to brown, shoots $0.2-$ 0.4(-0.6) $\mathrm{mm}$ wide. Branches postical intercalary, stolons lacking. Stem with distinct hyalodermis, cells of antical surface ca. 16-28×25-45 $\mu \mathrm{m}$, antical leaf-free zone distinct. Rhizoids with branched ends. Leaves suborbicular to ovate, oval and oblong, somewhat concave to plane, inserted obliquely or along the stem (as an exception subtransversely), mostly undecurrent or slightly decurrent with base of antical leaf margin \pm transversely inserted in European plants distinguished as subsp. catenulata and \pm distinctly decurrent in Asian plants known as subsp. nipponica; maximal leaf width near the middle or between the middle and lower thirds; sinus mostly U-like, sometimes V-like, ca. 0.35-0.6 leaf length; lobes \pm straight and acute. Uniseriate ends of lobes 1-2(3 ) cells long; terminal cell wall \pm stronger thickened at the apex. Lobe cells often \pm thick-walled, ca. 13-20($24) \times 20-25(-28) \mu \mathrm{m}$ at base of lobes, and $23-25 \times 25-30(-$ 35) $\mu \mathrm{m}$ in undivided part of the leaf. Dioicous. Female bracts with rather shallow sinus, $0.25-0.4(-0.5)$ their length, with a few remote to rather many marginal teeth or subdentate. Perianth mouth laciniate-dentate, serrate or dentate with teeth 1-4 to 5-6 cells long. Spores ca. 9$11 \mu \mathrm{m}, \pm$ densely vermiculate with \pm abundant fine outgrowths over vermiculations (SEM), about $1.5 \times$ as wide as elaters.

Variation. Cephalozia catenulata varies greatly in thickness of cell walls that causes much variability in habit of this species. Plants of mod. viridis may have \pm thin-walled cells of leaves and usually have \pm concave leaves with stronger thickened at the apex terminal cells of lobes whereas plants of mod. fusca develop evenly thick-walled cells and patent leaves with evenly thickened cell walls of terminal lobe cells. Structure of perianth mouth in $C$. catenulata is rather variable. It may develop cilia or teeth from 1-4 to 5-6 cells long (Hattori, 1944; Amakawa, 1952b; Müller, 1951-1958; Schuster, 1974; Paton, 1999; Damsholt, 2002). Sometimes cells of the mouth are destroyed by fungi.

Asian plants of the species were described as $C$. nipponica S. Hatt., known also as $C$. media var. nipponica and $C$. catenulata subsp. nipponica. Despite this taxon was recognized by Schuster (1974) as a synonym of $C$. catenulata it is still distinguished by Japanese bryologists (Yamada \& Iwatsuki, 2006). Comparative study of materials from Europe, Russian Caucasus, Far East and Japan has shown they are often distinct in leaf insertion when sterile. Seen plants from the Russian Far East and Japan differ from European plants in leaf insertion and decurrency mainly: in European plants leaves often \pm oblique inserted and \pm concave that makes ends of lobes \pm hidden; in the Far Eastern and Japanese plants leaves inserted nearly along the stem and plane that makes ends of lobes distinct. However, longitudinally inserted leaves occur in European plants of $C$. catenulata also (Müller (1951-1958: Fig. 417a; Ván̆a, pers. com., 2013). The other distinctions which we have no possibility to check were described by N. Kitagawa (1969) and H. Inoue (1985). Among them we have found no principal difference of subsp. catenulata and subsp. nipponica in cell size and lobe orientation with respect to each other. It is noteworthy that structure of mature spore surface in available specimens of $C$. catenulata subsp. catenulata and subsp. nipponica is somewhat different (Fig. 7: 2-4). Molecular study of Vilnet et al. (2012) confirms morphological distinctions of plants from the Far East and Japan. However, only one specimen of C. catenulata subsp. nipponica was involved in this study. Data on geographical variability, boundary in distribution of both subspecies and their morphological distinctions are still not clear. This persuades us to keep this species sensu lato to avoid confusion. Taxonomic status of C. catenulata subsp. nipponica needs to be clarified by morphological and molecular comparison of extensive materials through the whole range of the species.

Differentiation. Xylicolous plants of this species are distinct in minute size, deep green to brown pigmentation, mostly \pm oblique inserted (but nearly along the stem in subsp. nipponica and some European morphotypes) \pm ovate leaves (7-)8-16 cells broad with lobes gradually narrowed to the acute apex, sinus $0.3-0.5 .(-0.6)$ leaf-length, laciniate-ciliate to dentate perianth mouth and \pm dentate bracts.

Cephalozia catenulata may be confused with rather common C. lunulifolia, rare C. leucantha, C. macrostachya and with very rare $C$. macounii. It differs from extremely malleable $C$. lunulifolia in ability to develop brown pigmentation of cell walls, mostly smaller [13$20(-24) \times 20-25(-28)$ vs. $20-33 \times 25-40 \mu \mathrm{m}$ at base of lobes] and often thick-walled (vs. usually thin-walled) leaf cells, \pm dentate bracts and perianth mouth. It differs from $C$. leucantha in mostly \pm oblique (vs. subtransversely) inserted broader leaves - (7-)8-16 (vs. 4-12) cells wide, lobes 3-8 (vs. 2-5) cells wide at the base, dark green to brown (vs. pale whitish or rare yellowish green) colour, \pm dentate (vs. entire to subdentate) female bracts and perianth mouth with teeth to 4(-6) [vs. 1-2(-3)] cells long. Mod. parvifolia-angustifolia-densifolia of C. catenula$t a$ with nearly subtransverse leaves may be confused with C. macounii. It differs from the latter in broader leaves, (7-)8-16 vs. $3-7(-10)$ cells wide, and lobes $3-8$ vs. $2-4$ cells wide respectively. Moreover, plants of this modification of $C$. catenulata never develops long 3-celled uniseriate lobe ends of strongly elongate cells characteristic of C. macounii. Distinctions from C. macrostachya are described in the key above. 
Selected illustrations: Amakawa, 1952b: Figs. 8 K$\mathrm{U}$ (as C. media var. nipponica), $10 \mathrm{~A}-\mathrm{H}$ (as C. catenulata subsp. nipponica); Müller, 1951-1958: Fig. 417; Inoue, 1974: Pl. 60 (as C. nipponica); Schuster, 1974: Figs. 444: 3, 4; 450: 1-6, 451; Schljakov, 1979: Рис. 31: 2; Paton, 1999: Fig. 33; Iwatsuki et al., 2001: P1. 132: 2 (as C. catenulata subsp. nipponica); Damsholt, 2002: P1. 186.

World distribution. Suboceanic montane boreosubtropical: Europe, Caucasus, Russian Far East, NE China (Kirin), North America southward till mountains of Mexico (Ván̆a, 1993). Materials from Japan (Honshu, Shikoku, Kyushu), Thailand, Philippines are known as C. catenulata subsp. nipponica.

Distribution in Russia. Kaliningrad Region, Caucasus, southern Far East. Records of this species from Russian Arctic (Kanin Peninsula, Kolguev Isl.) by F. I. Ruprecht, 1841 (LE) are based on materials of Cephaloziella varians (Gottsche) Steph.

Ecology. Usually on rotten wood (very rare on peat, wet sandstone, and granite rocks) in mountain taiga, mountain deciduous coniferous and mountain subtropical forests, acidophilous.

Selected specimens examined: RUSSIA: Republic of Adygeya: vicinity of Guzeripl' Settlement, Filimonovskiy Brook in middle part of deep narrow canyon, beech-fir forest, on strongly decayed wood of fir, $693 \mathrm{~m}$ alt., 16.X.2007, Konstantinova \#K458-1a-07, KPABG-111659 (dupla in LE); Primorsky Territory: Ussuriyskiy Reserve, Upper Artyomovka River, decidous forest, on rotten wood on slope, IX.2010, Mamontov \#5/1-10 (LE) (males, mod. mesoderma-viridis vel. fusca). FINLAND: Savonia australis, par. Kangasniemi, Suomassi in silva abietina, ad truncos putrida, 28.VII.1874, Lackström s.n. (LE) (per.); POLAND: Beskidus Silesis, in ligno putrido picearum in silva picieto-abieteta, in "Biaia Wiseika" valle, in dextera rivuli ripa, 17.VII.1959, Grochowska s.n. (LE) (fr.); Gyry Stoiowe w Kotlinie Kiodzkiej, powiat Kiodzko, $820 \mathrm{~m}$ alt., ad saxa arenacea valde umbrosa insignia aëre semper valde humido inter peceas, 23.VIII.1952, Szweykowski s.n. (LE) (fr., mod. parvifolia-angustifolia-densifolia, C. macounii phenotype); Georgia: Western Transcaucasia, Adjarskaya ASSR, Botanical garden of Batumi, on bark of fallen beech, 24.VI.1961, Abramova \& Abramov s.n. (LE) (juv. per.); JAPAN: Miyazaki, Mt. Kirishima, ca. 1200 m alt., decaying wood, V.1951, Amakawa s.n. (LE) (mod. fusca, fr.).

Cephalozia connivens (Dicks.) Lindb., 1872. Contributio ad Floram Cryptogamam Asiae Boreali-Orientalis [Acta Soc. Sci. Fenn. 10]: 238. - Jungermannia connivens Dicks., 1801.. Fasc. Pl. Crypt. Brit. 4: 19. Pleurocladula connivens (Dicks.) Konstant., Vilnet \& Troitsky, 2012. Arctoa 21: 125. - Fuscocephaloziopsis connivens (Dicks.) Váňa \& L. Söderstr., 2013. Phytotaxa 112(1): 9. — Figs. 3, 6: 4, 8: 3.

Plants medium-size to small, whitish green, occasionally yellowish green, pellucid, without secondary pigmentation. Branches postical intercalary, stolons lacking. Stem in cross section often distinctly flattened, with distinct hyalodermis of very large antical cells in comparison with small thick-walled medullary cells; cells of antical surface of stem 40-75×(50-)60-90(-130) $\mu \mathrm{m}$, antical leaf-free zone distinct. Rhizoids often with swollen ends. Leaves oblique orbicular to broadly and narrowly ovate, plane to concave, (6-)9-20 cells wide, distinctly decurrent in plants of mod. laxifolia and hardly decurrent in plants of mod. densifolia; maximal leaf width near the middle, postical margin \pm stronger convex than antical; sinus \pm U- or rare narrow V-like, ca. (0.25-)0.3-0.6(-0.7) leaf-length; lobes acute, \pm connivent to subparallel, as a rule not crossing each other. Uniseriate ends of lobes 1-2 cells long, terminal cell wall \pm stronger thickened at the apex, 22-38 $\mu \mathrm{m}$ wide at the base. Cells at base of lobes ca. (25-)28-50($65) \times(30-) 37-70(-80) \mu \mathrm{m}$, with thin or somewhat thickened walls. Autoicous. Female bracts with laciniate to triangular entire or sparsely dentate lobes, deeply bilobed. Perianth mouth \pm laciniate- to lobulate-ciliate, with acuminate lacinae or lobules each at apex with 2-4(-5) celled cilia, which are conspicuous but fragile and may become eroded before the sporophyte matures. Spores ca. (9-)10 $15 \mu \mathrm{m}, \pm$ densely thickly reticulate-punctate (SEM), about as wide as elaters.

Differentiation. Cephalozia connivens is distinguished by its large cells and pellucid appearance, \pm connivent leaf lobes with rather broad and stronger thickened wall at the apex of terminal cells and broader apical cells at the base of 1-2-celled uniseriate ends (22-38 $\mu \mathrm{m}$ vs. $12-22 \mu \mathrm{m}$ in C. loitlesbergeri and C. lacinulata), frequent development of perianth with \pm laciniate-ciliate mouth. $C$. connivens may be confused with $C$. loitlesbergeri first of all. Despite leaf lobes of $C$. loitlesbergeri are considered connivent and crossing each other, the latter character is rather flexible. Size of leaf cells is also flexible in the both above mentioned species. Reliable distinction of $C$. loitlesbergeri is smaller cells and development of brownish pigmentation of older shoot sectors (vs. inability of $C$. connivens to develop brownish pigmentation of medulla and leaves). Seen brownish plants of $C$. connivens keep this colour because of colour of their cell content rather than pigmentation of cell walls characteristic of pigmented plants of C. loitlesbergeri. Uniseriate lobe ends in C. loitlesbergeri usually 2-3-celled, whereas in C. connivens 1-2-celled. The width of terminal cell of lobes at base is \pm stable, 22 $38 \mu \mathrm{m}$ wide vs. $12-20(-23) \mu \mathrm{m}$ in C. loitlesbergeri. As an exception $C$. connivens form solitary 3-celled uniseriate lobe ends with terminal cells till $15 \mu \mathrm{m}$ at base. Antical cortical cells are also broader in $C$. connivens than in $\mathrm{C}$. loitlesbergeri: (35-)40-75 $\mu \mathrm{m}$ vs. 20-35(-38) $\mu \mathrm{m}$ wide respectively. Confusion of $C$. connivens with sterile plants of $C$. pleniceps having large cells is also possible. They differ in \pm regularly stronger thickened vs. not or hardly stronger thickened in some leaves apical wall of terminal lobe cells; often connivent vs. not connivent leaf lobes; absence vs. sporadic presence of terminal branches and stolons; somewhat flattened stem with sharply defined hyalodermis on antical side. When perianths present they are distinct in lobulate- or laciniate-ciliate vs. crenulate- 
denticulate mouth and deeper (0.65-0.85) bilobed female bracts with laciniate to narrowly triangular lobes vs. shallower (0.4-0.6) bilobed bracts with rather broad lobes. Forms of $C$. connivens with somewhat thickened cell walls of leaves may be taken for C. macrostachya, which also may develop laciniate-ciliate perianth mouth. They differ from the latter in considerably larger cells, pellucid appearance, mostly spinous vs. not spinose lobe apices, autoicous sex distribution.

Cephalozia connivens may grow on rotten wood together with forms of $C$. bicuspidata with ciliate perianth mouth. When such perianths are in hand they may be easily confused with perianths of $C$. connivens. They differ from perianths of $C$. connivens in shallower bilobed female bracts, ciliate rather than laciniate mouth with cilia of narrower and less elongate cells.

Selected illustrations: Müller, 1951-1958: Fig. 410; Amakawa, 1952b (as C. connivens var. pachydermis $\mathrm{S}$. Hatt.); Schuster, 1974: Fig. 461; Schljakov, 1979: Рис. 29; Paton, 1999: Fig. 40; Damsholt, 2002: Pl. 195; Atherton et al., 2010: 94-95.

World distribution. Holarctic, most common in boreal and temperate areas with \pm humid microclimate. C. connivens subsp. fissa (Steph.) Ván̆a is known from Africa (Váňa, 1988) and C. connivens subsp. sandwichensis (Steph.) Váňa from Sandwich Islands (Hawaiian Islands). There are no doubtless records of $C$. connivens from Arctic.

Distribution in Russia. Widespread but not frequent through the whole Russia in forested and mountain areas mostly: from northern tundras to Subtaiga Subzone and Deciduous forest zones, also in mountain taiga and mountain deciduous coniferous forests. Record of C. connivens from Central Yamal Peninsula (Potemkin, 1993b) is based on materials of $C$. pleniceps mod. laxifolia. The specimens of the other records from the Russian Arctic should be in LE but not found.

Ecology. Acidophylous: on rotten wood, among Sphagnum, more rare among other mosses, on peaty, humus and fine sandy soil.

Selected specimens examined: RUSSIA: St. Petersburg Territory: vicinity of town of Sestroretsk, ... west bank of Glukhoe Lake, .... on peat among Sphagnum 23.VIII.2013 Potemkin \#230813-3 (LE) (per., mod. parviretis trans. ad $C$. loitlesbergeri); Leningrad Region: Stary Peterhoff, Zapovedny park. On bark of trees. 29.VII.1948 A. and I. Abramovs s.n., det. J. Duda as C. loitlesbergeri, LE (per.); Bolshaya Izhora Settl., mixed forest, on rotten stump. 1.VII.1984 Potemkin s.n. (LE) (per.); Bolshaya Izhora Settl., spruce forest, on rotten stump. 16.VIII.1984 Potemkin s.n. (LE) (C. pleniceps phenotype with slightly thickened wall at the apex of apical cell, as with $C$. bicuspidata with ciliate perianth mouth); Novgorod Region. Valdayskiy Natnl. Park, Zaschegorje Lake, margin of raised bog, 7.VIII.2003 E. N. Andrejeva as C. macrostachya (LE) (per., a form with somewhat thickened cell walls of leaves); Tver' Region, ... Raised Mire Starosel'skiy Mokh, on tussock side of Polytrichum strictum with wet Sphagnum nearby. 11.IX.2011 Potemkin, Kotkova Ц-63 (.) 271 (LE) (per.); Yaroslavl' and Volgda regions: Darvinskiy Reserve, Urochische
Krutets, on fine sandy soil among Dicranella cerviculata, Tetraphis pellucida, Calypogeia integristipula, etc. 29.VI.1988 Potemkin s.n. (LE) (fr., a form with slightly but regularly thickened apical walls of terminal cells). FINLAND: Ilomantsi Municipality, Korpi-Pampalo, on rotten wood in old growth spruce forest. 6.IX.2001 Potemkin, Lositskaya, s.n. (LE) (mod. densifolia, a form with \pm concave hardly decurrent leaves). LATVIA: Bryotheca Baltica Nr. 183. Livland, Kreis Riga... 1.VI.(= 14.VI)1908 Joh. Mikutowicz s.n. (LE) (per., fr.). JAPAN: S. Hattori: Hep. Jap. 514. On dacaying stump of Cryptomeria japonica, ca. $100 \mathrm{~m} \mathrm{s.} \mathrm{m}$. [Central West Hoshu] 10.X.1957 Y. Ikegami (LE). USA: W. S. Sullivant: Musci Alleghaniensis 246. In ligno putrido. 1854 W. S. Sullivant (LE)

Cephalozia lacinulata (J. B. Jack ex Gottsche \& Rabenh.) Spruce, 1882. On Cephalozia: 45. - Jungermannia lacinulata J. B. Jack ex Gottsche \& Rabenh., 1877. Hep. Eur., no. 624. - Fig. 3.

Plants small to minute, whitish green, pellucid, shoots $0.3-0.55 \mathrm{~mm}$ wide. Branches postical intercalary, stolons lacking. Stem with distinct hyalodermis, colourless or occasionally with brownish medulla; cells of antical surface of stem ca. $25-35 \times 60-80 \mu \mathrm{m}$, medullary cells \pm thick-walled, antical leaf-free zone distinct. Rhizoids with branched ends. Leaves broadly ovate to ovate-rectangular, plane, 4-7(-8) cells wide, not or slightly decurrent - base of antical margin inserted \pm along or at some angle to the stem; maximal leaf width near or below the middle, postical margin convex and usually \pm similar to the antical; sinus mostly V-like acute at the base, sometimes U-like, ca. 0.45-0.7 leaf length; lobes acute, not or slightly connivent. Uniseriate lobe ends 1-2(-3) cells long, terminal cell wall distinctly stronger thickened at the apex, 12-20(-22) $\mu \mathrm{m}$ wide at the base. Cells at base of lobes ca. $20-45 \times 25-50 \mu \mathrm{m}$, thin- to slightly thick-walled. Dioicous. Usually fertile. Female bracts ovate to ovate rectangular, bilobed for $0.5-0.7$ their length, with triangular mostly \pm entire lobes. Perianth mouth narrowly laciniate-ciliate with lacinae 2-6 cells wide, 4-7 cells long, with uniseriate ends $2-3$ cells long. Spores ca. (9-)10-15 $\mu \mathrm{m}, \pm$ vermiculate $(\mathrm{LM}), \pm$ equal in diameter to elaters.

Differentiation. Cephalozia lacinulata may be easily confused with sterile plants of mod. parvifolia-angustifolia-laxifolia of C. bicuspidata, C. hamatiloba and $C$. connivens. However, it is dioicous and often produces perianths and male plants not characteristic of juvenile plants of autoicous $C$. bicuspidata and $C$. connivens. Moreover it is distinct from juvenile plants of C. bicuspidata and C. hamatiloba in common perianth formation with laciniate-ciliate mouth, distinctly (vs. slightly) thickened tips of uniseriate lobe ends, frequently thickened medullary cells and distinctly branched rhizoid ends. $C$. lacinulata is distinct from $C$. connivens in leaves $4-5$ to at most 7(-8) vs. (6-)9-20 cells wide, terminal lobe cells at base $12-20(-22)$ vs. $22-38 \mu \mathrm{m}$ wide, rhizoids with distinctly branched vs. slightly swollen or indistinctly branched ends and bracts remotely dentate vs. often entire and perianth mouth with uniseriate ends of cilia 2-3 
vs. 2-4(-5) cells long. When leaves in C. lacinulata broad they are mostly asymmetric like in $C$. connivens.

Selected illustrations: Müller, 1951-1958: Fig. 406; Schuster, 1974: Fig. 464; Schljakov, 1979: Рис. 31: 1; Damsholt, 2002: Pl. 196.

World distribution. Mostly in boreal and temperate areas. Europe, N. America, Caucasus, S. Siberia. When sterile it is subject to be overlooked.

Distribution in Russia. Caucasus, S. Siberia. Record from the Leningrad Region (Zhukova, Potemkin, 1987) is based on sterile juvenile $C$. bicuspidata. However, taking into account the finds of the species in adjacent territories of South Finland, near Lojo, ca. $50 \mathrm{~km}$ east of Helsinki (S. Piippo: Hep. exs. S. O. Lindbergii. 394) it is possible to find some relict localities of this species in untouched old growth forests with invariably wet microclimate near large lakes of the Leningrad, Novgorod or Pskov regions.

Ecology. Restricted to decaying wood in deep shade and high humidity areas, often near streams, lakes, bogs and in shade of conifers. Restricted to shaded flanks of logs, almost never occurring on their exposed upper faces.

Selected specimens examined: RUSSIA: Buryatia: Khamar-Daban Range, Lower Osinovka River, mixed herb forest, on old rotten wood in shade, 6.VII.1990, Kazanovsky s.n. (LE, dupla ex IRK) (male plants with admixture of C. macounii). SWEDEN: Gästrikland: Hille par., Hillemyren, 25.V.1952, Arnell s.n. (LE) (per.); FINLAND: Regio aboensis: Par. Lojo, lign. putr. loco valdeabscondito et depresso et umbroso in piceegno humido ad Tytyri, .... sociis $C$. connivens et media, 23.VI.1885, Lindberg s.n. (LE) (per.).

Cephalozia loitlesbergeri Schiffn., 1912. Oesterr. Bot. Z. 62: 10(:2). - Pleurocladula loitlesbergeri (Schiffn.) Konstant., Vilnet \& Troitsky, 2012. Arctoa 21: 125. - Fuscocephaloziopsis loitlesbergeri (Schiffn.) Ván̆a \& L. Söderstr., 2013. Phytotaxa 112(1): 10. — Figs. 3, 6: 3

Plants medium-size whitish green, pellucid, often brownish in older shoot sectors. Branches postical intercalary, stolons rare. Stem with distinct hyalodermis; cells of antical surface of stem $17-38 \times 25-110 \mu \mathrm{m}$ [after Paton (1999) considerably wider: $28-45(-55) \mu \mathrm{m}]$, medullary cells thick-walled, antical leaf-free zone distinct. Rhizoids often with swollen ends. Leaves broadly ovate to suborbicular or occasionally oval, plane to occasionally somewhat concave or convex, slightly to distinctly decurrent - base of antical margin inserted along the stem; maximal leaf width between the middle and lower thirds, near the middle or at the lower third, postical margin \pm stronger convex than antical; sinus slit-like, narrow V- or \pm U-like, ca. (0.3-)0.4-0.7(-0.8) leaf-length; lobes acuminate or ciliate, less often acute, (2-)3-6(-8) cells at the base. Uniseriate lobe ends (1-)2-3(-4) cells long. Lobe ends mostly somewhat to distinctly connivent and sometimes cruciate, terminal cell wall \pm stronger thickened at the apex, terminal cell often curved or twist- $e d$ and than distinguished with difficulty, often considerably more narrow than underlying cell, 12-20(-23) $\mu \mathrm{m}$ wide at the base. Cells of leaves extremely variable in size even on the same shoot, at base of lobes ca. (15-)20 $35(-38) \times(20-) 25-55(-65) \mu \mathrm{m}$, in undivided part of leaves ca. $20-38(-50) \times 25-52 \mu \mathrm{m}$, with thin- to somewhat thickened not rare brown walls. Autoicous. Female bracts deeply 4(-6)-lobed, with \pm entire and narrow to nearly linear lobes. Perianth mouth \pm laciniate-ciliate, with cilia $2-6$ cells long. Spores ca. 10-12.5 $\mu \mathrm{m}, \pm$ densely thickly reticulate-punctate (SEM), about as wide as elaters.

Differentiation. This helophytic species is a subject of confusion with $C$. connivens. Their distinctions are described above under $C$. connivens. Sterile plants of C. loitlesbergeri may be confused with C. macrostachya which often develops connivent lobes and brownish pigmentation. C. loitlesbergeri is distinct from C. macrostachya in mostly narrower and often distinctly decurrent leaves with longer (1-)2-3-celled vs. 1-2-celled uniseriate lobe ends. Moreover, $C$. loitlesbergeri is autoicous and has female bracts with laciniate lobes and entire margins whereas Russian populations of C. macrostachya are dioicous and have female bracts with triangular lobes and often sparsely denticulate or dentate margins.

Selected illustrations: Müller, 1951-1958: Fig. 408; Schuster, 1974: Fig. 460; Schljakov, 1979: Рис. 30; Раton, 1999 : Fig. 39; Damsholt, 2002: P1. 194.

World distribution. Circumboreal with a few extensions into southern Arctic. In North America is known from eastern part only.

Distribution in Russia. From western to eastern Russia, with few locations in West and Central Siberia and northern Far East. From Southern tundras to Subtaiga subzone, mountain taiga. In Russian Arctic very rare and known from Polar Urals and Taymyr Peninsula only.

Ecology. Helophytic, usually among Sphagnum and associates with variety of liverworts of the Mylia-Cladopodiella associule.

Selected specimens examined: RUSSIA: Republic of Karelia: Suojärvi District, Tolvojärvi, in upper mire among Sphagnum sp., Potemkin \& Kotkova \#7107-4, 5 (LE) (per.); Planned Tulos National Park Karhukolmio Area, Sphagnum mire, among Sphagnum, Potemkin \#(.)707 (LE); St. Petersburg Territory: vicinity of town of Sestroretsk, west of Glukhoe Lake, on compacted wet peat on path in Sphagnum pine forest, Potemkin \#230813-2b (LE) (per.); Leningrad Province: $9.5 \mathrm{~km} \mathrm{NNE} \mathrm{of}$ town of Zelenogorsk, Lammin-suo Mire, on Sphagnum tussock, 23.V.1991, Potemkin s.n. (LE); Novgorod Province: Krestetskiy Uezd, Spasskie Bolota, 1919, Spiridonov s.n. (LE); Khanty-Mansi Autonomous District: Tyumen' Region, Yugra, Middle Ob' River, swampy pine dwarf shrub-Sphagnum forest, in depression on the path side, 21.VII.2000, Czernyadjeva s.n. (LE) (fr.); Sovetskiy Region, Nature Park Kondinskie Ozera (6151'21' N 71 ${ }^{\circ} 57^{\prime} 56^{\prime}$ " E), upper mire massif east of Pontur Lake, ridge-hollow complex, on margin of Sphagnum tussock, Filippov N30-06 (KPABG115865) (fr.). SWEDEN: Sverige, Södermanland 6.VIII.1915, Arnell s.n. (LE); GERMANY: Bayern, Bernau am Chiemsee, Rottauer Filtze, ca. $550 \mathrm{~m}$ alt., 15.XI.1902, Paul s.n. (LE) (per.). 
Cephalozia lunulifolia (Dumort.) Dumort., 1835. Recueil Observ. Jungerm. 18. - Jungermannia lunulifolia Dumort., 1831. Syll. Jungerm. Europ.: 61. - Cephalozia media Lindb., 1881. Meddeland. Soc. Fauna Fl. Fenn. 6: 242. — Pleurocladula lunulifolia (Dumort.) Konstant., Vilnet \& Troitsky, 2012. Arctoa 21: 125. - Fuscocephaloziopsis lunulifolia (Dumort.) Váňa \& L. Söderstr., 2013. Phytotaxa 112(1): 10. — Figs. 4, 5: 2, 8: 2.

Plants medium-size whitish green, without secondary pigmentation. Branches postical intercalary, stolons lacking. Stem with distinct hyalodermis; medullary cells \pm thick-walled; cells of antical surface of stem ca. 25$40(-45) \times 40-60(-80) \mu \mathrm{m}$, antical leaf-free zone distinct. Rhizoids often with branched ends. Leaves orbicular to ovate-orbicular, plane to slightly concave in plants of mod. parvifolia-densifolia, often with stronger convex postical margin, hardly to distinctly decurrent - base of antical margin inserted usually along the stem, maximal leaf width mostly in the middle third, sometimes lower; sinus mostly \pm U-like, ca. 0.3-0.5 leaf-length; lobes acute, mostly not or slightly connivent. Cells at base of lobes ca. $20-33 \times 25-40 \mu \mathrm{m}$. Uniseriate lobe ends $1-2$ cells long, (20-)25-33(-38) $\mu \mathrm{m}$ wide at the base, terminal cell wall chiefly strongly thickened at the apex. Dioicous. Androecia on main shoot or on short lateral branches. Female bracts \pm entire, sinus $0.3-0.5$ the length, open, not slitlike at the base. Perianth mouth \pm crenulate-dentate with teeth $0.5-1.5(-2)$ cells long. Spores ca. 8-10(-?12) $\mu \mathrm{m}$, distinctly reticulate-punctate, meshes ca. $1-1.5 \mu \mathrm{m}$ (SEM), about $1.5 \times$ as wide as elaters.

Differentiation. Cephalozia lunulifolia appears to be one of the most widespread species of Cephalozia in Russia. It has very broad ecological amplitude and variability. C. lunulifolia might be confused with C. affinis, C. pleniceps, C. catenulata and C. macrostachya. Differentiation from two former species is described in the key above, from two latter in comments to these species.

Selected illustrations: Müller, 1951-1958: Fig. 413414; Amakawa, 1952b: Fig. 8: $A-J$; Schuster, 1974: Fig. 458; Schljakov, 1979: Рис. 27: 2; Paton, 1999: Fig. 37; Iwatzuki et al., 2001: Pl. 133: 6. Damsholt, 2002: Pl. 192.

World distribution: Holarctic boreal species, extending to Japan (Honshu, Shikoku, Kyushu) and SW China (Yunnan). The southernmost locality in Cuba.

Distribution in Russia. Widespread. From northern limits of Tundra Zone to subtropical mountain forests in Caucasus and mountain deciduous coniferous forests in the Far East.

Ecology. Among Sphagnum, on rotten wood, more rare among other mosses, on humus soil, rocks and fine sandy soil.

Selected specimens examined: RUSSIA: Leningrad Province: $3 \mathrm{~km}$ SW from Muraveyno Village, at base of small spruce near spring in constantly wet conditions, 6.VI.1991, Potemkin s.n. (LE) (per., incl. robust forms with leaves up to 15 cells wide); Novgorod Province: Khvoyninsky District, on pine log in herb blueberrySphagnum spruce forest, Potemkin \#70612-2 (LE); Yaroslavl' Prov- ince: Darviskiy Reserve, ditch from the bog to Zaliv Krutets, on \pm open places, probably on rotten wood debris, 12.VI.1990, Potemkin s.n. (LE) (in C. leucantha folder: males, per., fr., mod. pachyder$m a$ with mostly evenly thickened walls at apices of terminal cells of lobes); Orel Province, on pine log, among C. bicuspidata, Kotkova \#OP-09-95 (LE) (juv. per.); Yamalo-Nenetsky Autonomous District: Yamal Peninsula, ... Middle Khytyyaha River, tussockmoss tundra (among mosses and lichens), 26.VII.1977, Andrejeva s.n. (LE) (mod. megafolia, leaves up to 17 cells wide; stem with 16-18 medullar cells and 30-35 outer cells.). Chukotka Autonomous District: Upper Ioniveem River, 8.VII.1969, Plieva s.n. (LE) (mostly with evenly thickened walls of terminal cells of lobes). FINLAND: North Karelian Biosphere Reserve, Ilomantsi Municipality, Korpi-Pampalo, on litter in depression, Potemkin \& Lositskaya \#110901 (LE) (per.); GEORGIA: Western Transcaucasia, Batumi Botanical Garden, in beech forest on rotten wood, 17.VI.1961, Abramovs s.n. (LE) (per., fr., males); USA: Alaska, Seward Peninsula, Serpentine Hot Springs, tussock tundra, Potemkin \#92 06304 (LE) (per).

Cephalozia macrostachya Kaal., 1902. Rev. Bryol. 29: 8. - Pleurocladula macrostachya (Kaal.) Konstant., Vilnet \& Troitsky, 2012. Arctoa 21: 125. - Fuscocephaloziopsis macrostachya (Kaal.) Váňa \& L. Söderstr., 2013. Phytotaxa 112(1): 10. — Fig. 3.

Plants medium-size to minute, green to brownish. Branches postical intercalary, stolons lacking. Stem with distinct hyalodermis, antical cortical cells ca. 16-45($48) \times 38-65(-80) \mu \mathrm{m}$, medullary cells with strongly thickened walls that often pigmented in older stem sectors, antical leaf-free zone distinct. Rhizoids with branched and swollen ends. Leaves broadly ovate to suborbicular, slightly concave or broadly canaliculate (that makes sinus hardly discernible when observed with hand-lens), inserted mostly along the stem, not or slightly or rare distinctly decurrent. Sinus narrow V- and U-like, 0.30.6 leaf-length, lobes with 1-2-celled straight to \pm connivent or sometimes cruciate, uniseriate ends of \pm slightly elongate cells. Cells at lobe base ca. $17-25(-30) \times 22-$ $36 \mu \mathrm{m}$, often \pm evenly thick-walled and look remarkably smaller than lower or lowermost leaf cells, 28-45($48) \times 40-60(-65) \mu \mathrm{m}$, terminal cell mostly gradually rounded at the apex, not spinose, its wall chiefly a little thicker at the apex or \pm evenly thickened; base of antical leaf margin \pm obliquely inserted. Dioicous. Female bracts scarcely denticulate to entire or spinose-dentate with narrowly lanceolate lobes, sinus ca. 0.5-0.75 leaf-length, $\gamma$ like and \pm closed at the base. Perianth mouth laciniateciliate to irregularly dentate or denticulate with teeth or cilia of elongate cells, 1-5 cells long. Spores not seen, 10-15 $\mu \mathrm{m}$, verruculose (LM), a little wider than elaters.

Differentiation. Cephalozia macrostachya is often distinct in field due to broadly canaliculate leaves with often \pm narrow and indistinct sinus because of leaf concavity and close position of lobes (Potemkin, 1995; Paton, 1999: 107), frequent development of brown pigmentation of older shoot sectors and of medulla which looks distinct because of often rather large and pellucid antical cortical cells. This species, however, is variable and some 
its phenotypes are difficult to distinguish from C. lunulifolia and C. catenulata. It is distinct from the former in frequent development of brown pigmentation of medulla and leaves in older shoot sector (vs. not pigmented medulla and leaves), often laciniate-ciliate to dentate (vs. crenulate to short denticulate and occasionally lobulate-dentate) perianth mouth, deeper bilobed and often dentate bracts with narrower lobes and slit-like sinus at the base. C. macrostachya may be distinct from $C$. lunulifolia also in \pm certain (vs. uncertain) differentiation of smaller lobe cells from cells of undivided part of leaf and rather common development of evenly thickwalled (vs. mostly thin-walled) leaf lobe cells. When plants of C. macrostachya grow among Sphagnum they often develop \pm evenly thick-walled leaf cells with indistinct thickening of terminal lobe cells at the apex whereas $C$. lunulifolia in such conditions form thin-walled cells with \pm distinct thickening of terminal lobe cell at the apex. Because of often \pm connivent and sometimes cruciate lobes and development of brown pigmentation $C$. macrostachya may be confused with $C$. loitlesbergeri. It is distinct from the latter in dioicous inflorescens (Russian populations), somewhat canaliculate leaves with more closed and often indistinct sinus, broader lobes with less elongate uniseriate ends of usually $1-2$ cells, whereas in C. loitlesbergeri uniseriate ends often spinous-ciliate and 2-3-celled. Distinctions from C. catenulata are described in the key above.

Selected illustrations: Müller, 1951-1958: Fig. 416; Schuster, 1974: Fig. 452; Potemkin, 1995: Fig. Cephalozia macrostachya Kaal.; Paton, 1999: Fig. 34; Damsholt, 2002: Pl. 187.

World distribution. Nothern amphiatlantic species. Northern and Central Europe, Eastern North America

Distribution in Russia. Leningrad Region southwards of Karelian Isthmus, St. Petersburg Teritory, Kaliningrad Region (Dietzov, 1938). Records from West Siberia Khanty-Mansyisk Autonomous District (Lapshina, Konstantinova, 2012) are based on materials of C. loitlesbergeri. The species was also recorded for Pskov and Novgorod regions. Record for Novgorod Region (Andrejeva, 2009: Valdayskiy Natnl. Park. Zaschegorje Lake, margin of raised bog, 07.08.2003 E. N. Andrejeva, LE) is based on materials of $C$. connivens. Materials from Pskov Region were unavailable for this study.

Ecology. Acidophylous, on upper mires in getting dry black pools and among Sphagnum, associates with Kurzia pauciflora (Dicks.) Grolle, C. loitlesbergeri, Cladopodiella fluitans (Nees) H. Buch, Mylia anomala (Hook.) Gray, Gymnocolea inflata (Huds.) Dumort.

Selected specimens examined: RUSSIA: St. Petersburg Territory: vicinity of town of Sestroretsk, west bank of Glukhoe Lake, on compacted wet peat on path in Sphagnum pine forest, Potemkin \#230813-2a (LE) (per., C. lunulifolia phenotype - a form with subentire to remotely denticulate female bracts and denticulate to dentate perianth mouth Fig. 3: C. macrostachya-upper drawing); Leningrad Province: ... Lammin-suo Mire, black pools (ruoppa), 1991, Potemkin s.n. (LE) (robust forms); Kurgalsky Peninsula, .... among Sphagnum cuspidatum, Smagin \#65Á(LE). SWEDEN: Musci Suecici, Labels unclear, ?Gotland, 21.VIII.1926 et IX.1926, Söderberg s.n. (LE); GERMANY: Oberbayren: Hochmoor bei der Moorkulturstation Bernau am Chiemsee, ca. 520 m alt., IX.1912, Paul s.n. (LE); Wahner Heide: Hühnerbruch, Flora des Rheinlandes, zwischen Sphagnum medium in klinen Löchern, 15.VIII.1930, Schumacker s.n. (LE).

\section{Group IX Leucanthae (Cephalozia leucantha)}

Plants minute, whitish green, soft-textured. Branches postical intercalary, stolons lacking. Stem with distinct hyalodermis of slightly to moderately thick-walled cells, medulla of slightly to strongly thick-walled cells, antical leaf-free zone distinct, antical cortical cells much broader than basal leaf cells. Leaves about as wide as stem and as wide as long, not constricted at base, usually subtransversely saccubously inserted and undecurrent, slightly concave, 0.35-0.65-bilobed, antical half of leaf often larger than postical; lobes \pm triangular-lanceolate, $2-5$ cells broad at base, with 1-2-celled uniseriate ends of not or slightly \pm elongate cells and terminal cell wall hardly to distinctly thickened at apex. Underleaves lacking on sterile shoots.

Cephalozia leucantha Spruce, 1882. On Cephalozia: 68. - Pleurocladula leucantha (Spruce) Konstant., Vilnet \& Troitsky, 2012. Arctoa 21: 125. - Fuscocephaloziopsis leucantha (Spruce) Váňa \& L. Söderstr., 2013. Phytotaxa 112(1): 10. — Figs. 3, 7: 1.

Plants minute, often worm-like, without secondary pigmentation, shoots 0.15-0.3(-0.4) mm wide. Branches postical intercalary, stolons lacking. Stem thick in comparison with shoot width, often looks fleshy, hyalodermis and medulla of slightly to strongly thick-walled cells, antical leaf-free zone distinct, antical cortical cells (16-)20-30(-34) $\times 25-45(-60) \mu \mathrm{m}$, often somewhat thickwalled. Rhizoids often with branched ends. Leaves on sterile shoots usually small and distant, 4-12 cells broad, not conceal the stem, nearly transversely inserted and then undecurrent or rare obliquely inserted and then tend to be decurrent, broadly ovate, often slightly concave, sinus narrowly rounded to acute, $0.35-0.65$ leaf-length. Lobes not connivent, $2-5$ cells broad, with 1-2-celled uniseriate ends of not or slightly elongate cells; antical lobe (part of leaf) often longer (larger) than postical. Cells at base of lobes \pm thick-walled, ca. 10-20×16-28 $\mu \mathrm{m}$, terminal cell wall \pm stronger thickened or \pm evenly thickened at the apex. Dioicous. Female bracts entire to subdentate with rather shallow sinus, $0.3-0.6$ the length. Perianth mouth \pm crenulate-dentate to dentate-short ciliate, with teeth of 1-2(-3) slightly to rather strongly elongate cells. Spores (8-)9-11(-12) $\mu \mathrm{m}, \pm$ densely vermiculate (SEM), a little wider than elaters.

Differentiation. Small \pm remote often scale-like and not concealing the stem leaves with sinus $0.35-0.65$ their length and often distinctly shorter postical lobes as well as flesh \pm worm-like stem, $55-130 \mu \mathrm{m}$ wide, make $C$. leucantha distinct even in a field. 
Cephalozia leucantha is distinct from C. macounii in sterile leaves with shallower sinus $(0.35-0.65$ vs. $0.55-$ 0.8 the leaf length), which are \pm distant and not conceal the stem, distinct antical leaf-free zone, considerably broader antical cortical cells than basal leaf cells and entire to subdentate female bracts with shallower sinus (0.3-0.6 vs. $0.5-0.7$ the length). Distinctions of C. leucantha from $C$. catenulata are considered in comments to the latter species.

Selected illustrations: Müller, 1951-1958: Fig. 418; Inoue, 1974: Pl. 59; Schuster, 1974: Fig. 444: 11, 455; Schljakov, 1979: Рис. 32: $a-3$; Paton, 1999: Fig. 36; Iwatzuki et al., 2001: P1. 132: 4; Damsholt, 2002: P1. 190.

World distribution. Holarctic: from Arctic to mountain deciduous coniferous forests.

Distribution in Russia. Widespread, \pm sporadic in European, Siberian and Far Eastern Russia, from northern tundra to subtaiga, from mountain taiga to mountain tundra and mountain deciduous coniferous forests.

Ecology. Occasionally on peaty, rare on mineral soil, among Sphagnum and other mosses and on rotten wood.

Selected specimens examined: RUSSIA: Murmansk Province: Kandalakshsky Coast of the White Sea, ... on peaty soil along stream, 17.VIII.1994, Konstantinova \& Schuster s.n. (LE) (per., males); Zinserling, on stump of spruce, 8.X.1930, Zinserling s.n. (LE) (a form with often \pm longitudinally inserted leaves); Leningrad Province, vicinity of town of Zelenogorsk, bank of Lyublinskoe Lake, on \pm dry hillock near quick spring, on peaty soil, 8.VII.1989, Potemkin s.n. (LE) (fr.); vicinity of Bol'shaya Izhora Settlement, mixed forest, on rotten wood, 27.VII.1984, Potemkin s.n. (LE) (mod. mesoderma with thick stem and strongly thickened medullary cells); Republic Sakha/ Yakutia: Lensk District, Kudalakh River, on bank of stream, 25.VIII.2002, Sofronova s.n. (SASY, LE); Chukotkij Autonomous District: Mys Vankarem, Sphagnum-Hypnum peatland, 28.VII.1934, Gorodkov s.n. (LE); Primorsky Territory: Mt. Livadijskaya (Pidan), Ayry River, at the base of tree, Mamontov \#43/2-10 (LE) (per). FINLAND: North Karelian Biosphere Reserve, Kotavaara, blueberry pine forest with spruce, on rotten wood, Potemkin \& Lositskaya \#18601 (LE) (per.); USA: Alaska, Seward Peninsula, Killeak Lakes, southernmost lake, on wet high-centered polygon, Potemkin \#92 09901 (LE) (per.).

Cephalozia leucantha var. robusta Schljakov, 1973. Novosti Sist. Nizsh. Rast. 10: 304.

Type materials have not been found yet in LE and KPABG. Taxonomic position is not clear. According to original description (Schljakov, 1973) it is distinct from the type variety in larger size of plants, leaves and cells: "Planta quam var. leucantha major, surculis ad $0.6-0.8 \mathrm{~mm}$ latis. Folia caule duplo et ultra latiora, ad 400(-450) $\mu$ longa, ad $380(-420) \mu$ lata, ad 3/10-3/8(-1/2) longitudinis in lobos obtusos divisa. Cellulae in parte foliorum media ad $23 \mu$ latae". This taxon, according to illustration and description, may be confused with C. ambigua, small forms of $C$. bicuspidata and C. lunulifolia. It is distinct from the former in distinct antical leaf-free zone and absence of terminal branches, from the latter in frequent development of small leaved branches with habit of typical C. leucantha.
Illustrations: Schljakov, 1973: 303 - Cephalozia leucantha Spruce var. robusta Schljak.

\section{EXCLUDED TAXON:}

Cephalozia rigida Lindb., 1872. Bot. Not. 1872: 165. The species was recorded for Republic of Karelia (Lindberg, 1872) and is known as Jungermannia rigida Lindb., nom. illeg. and Sphenolobus rigidus (Lindb.) Müll. Frib. C. rigida was described from Finland and Russian Karelia (Dvoretz in Karelia onegensi, 20 Aug. 1869 J. Sahlberg, H-SOL) in rather little known paper of S. O. Lindberg (1872) devoted to Scandinavian bryophytes. Later S. O. Lindberg and E. Fr. Lackström (1874) transfer Cephalozia rigida to the genus Jungermannia as J. rigi$d a$ (Lindb.) Lindb. \& Lackstr. This name and J. rigida Lindb. 1872 are later homonyms and nom. illeg. (Art. 64.1.) (Index Hepaticarum, 1987). The latter fact resulted in reestablishing of $J$. rigida Lindb. as $J$. subdichoto$m a$ Lindb. in 1883. Plants have much in common with Sphenolobus and some phenotypes of Cephalozia ambigua. Revision of materials kept in $\mathrm{H}$ has shown it represents mod. parvifolia-densifolia of Gymnocolea inflata. Identity of this taxon to Gymnocolea inflata was confirmed by $\mathrm{H}$. Buch identifications as well.

\section{ACKNOWLEDGEMENTS}

We are grateful to all our colleagues who helped us in different ways to fulfil this work. Nadezhda Konstantinova, Michael Ignatov and Yuriy Mamontov kindly provided selected specimens of Cephalozia important for this study. Nijole Kalinauskaite helped much with literature. Lyudmila Kartseva has provided skilful assistance with preparation of SEM images of spores. Jiří Váňa and Michael Ignatov are gratefully acknowledged for critical reading and fruitful consideration of the first versions of manuscript. Anna Mehaka is thanked for careful reading of the last version of manuscript and help with English. Consideration on interpretation of available molecular data on the family Cephaloziaceae and advices on this topic of Vera Malysheva, Ekaterina Malysheva and Yuriy Mamontov are kindly acknowledged. The study was partly supported by the Program of Basic Research of the Presidium of RAS "Wildlife: Current Status and Problems of Development" (Subprogram: "Biodiversity: state and dynamics").

\section{LITERATURE CITED}

[ABRAMOVA, A.L. \& J. DUDA] АБРАМОВА А.Л., Й. ДУДА 1962. О Cephalozia pleniceps Lindb. с Кавказа - [On Cephalozia pleniceps Lindb. from Caucasus] - Бот. матер. omd. cnop. pacm. [Bot. Mater. Otd. Spor. Rast.] 15: 163-165

AMAKAWA, T. 1952a. Studies on the Japanese species of Cephalozia (Hepaticae). 1. - J. Hattori Bot. Lab. 7: 69-75.

AMAKAWA, T. 1952b. Studies on the Japanese species of Cephalozia (Hepaticae). 2. - J. Hattori Bot. Lab. 8: 55-62.

[ANDREJEVA, E.N.] АНДРЕЕВА Е.Н. 2009. Мохообразные. - [Bryоphytes] В кн.: Кадастр флоры Новгородской области (ред. Юрова, Э.А., Л.И. Крупкина, Г.Ю. Конечная) Великий Новгород, Изд-во «Лeмa»]: [In: Yurova, E.A., L.I. Krupkina \& G.Yu. Konechnaya. Kadastr flory Novgorodskoy oblasti. Veliky Novgorod, Izd-vo «Lema»]: 227-246.

ATHERTON, I., S. BOSANQUET \& M. LAWLEY (eds.) Mosses and 
liverworts of Britain and Ireland. A field guide. 2010. - British Bryol. Soc. Plymouth. 848 pp.

[BAКALIN, V.A.] БАКАЛИН В.А. 2005. Schofieldia Godfrey и Cryptocoleopsis Amakawa - новые роды печеночников (Hepaticae) для флоры России. - [Schofieldia Godfrey and Cryptocoleopsis Amakawa, the new genera of liverworts (Hepaticae) for the Russian flora] Бom. журн. [Bot. Zhurn.] 90(4): 594-603.

BAKALIN, V.A., V.YA. CHERDANTSEVA, M.S. IGNATOV, E.A. IGNATOVA \& T.I NYUSHKO 2009. Bryophyte flora of the South Kuril Islands (East Asia). - Arctoa. 18: 69-114.

DAMSHOLT, K. 2002. Illustrated flora of Nordic Liverworts and Hornworts. - Nord. Bryol. Soc., Lund. 840 pp. [Pl. 183-196].

DIERSSEN, K. 2001. Distribution, ecological amplitude and phytosociological characterization of European bryophytes. - Bryophyt. Bibl. Bd. 56. $289 \mathrm{pp}$.

DIETZOV, L. 1938. Die Mosse AltpreuBens und ihre Standorte - Jahrensbericht des Preuвischen botanischen Vereins. Königsberg: 1-84.

DUELL, R. 1983. Distribution of the European and Macaronesian liverworts (Hepaticophytina). - Bryol. Beitr. 2 (1. Januar 1983): 1-115.

ENGEL, J.J. 2007. Studies of New Zealand Hepaticae. 20-38. A Miscellanea of New Taxa and Combinations. - Novon: A Journal for Botanical Nomenclature 17(3): 310-314.

FELDBERG, K., J. HEINRICHS, A.R. SCHMIDT, J. VÁŇA \& H. SCHNEIDER 2013. Exploring the impact of fossil constraints on the divergence time estimates of derived liverworts. - Plant Syst. Evol. 299: 585-601.

GODFREY, J.D. 1976. Schofieldia, a new hepatic from the Pacific Northwest. - Bryologist 79: 314-320.

GROLLE, R. 1968. Monographie der Gattung Nowellia. - J. Hattori Bot. Lab. 31: 20-49.

HATTORI, S. 1944. Contributio ad Floram Hepaticarum Austro-Kiushiuensem. - Bull. Tokyo Sci. Mus. 11: 1-203.

INDEX HEPATICARUM 1987. In: Geissler, P. \& H. Bischler. Jungermannia to Lejeunites. Berlin, Stuttgart 8/9, $2^{\text {nd: }} 310 \mathrm{pp}$.

INOUE, H. 1974. Illustrations of Japanese Hepaticae. - Tokyo, Tsukiji Shokan Publishing Co. 189 pp.

INOUE, H. 1985. Taxonomic miscellany on hepatics (4). - J. Jap. Bot. 60(11): 332-336.

IWATSUKI, Z., H. DEGUCHI \& T. FURUKI 2001. Mosses and Liverworts of Japan, colour plates 1-192. - Heibonsha, Ltd., Tokyo. 355 pp.

KITAGAWA, N. 1969. Studies on the Hepaticae of Thailand. II. Cephalozia and Cephaloziella. - J. Hattori Bot. Lab. 32: 290-306

[KONSTANTINOVA, N.A., V.A. BAKALIN \& A.D. POTEMKIN] КОНСТАНТИНОВА Н.А., В.А. БАКАЛИН, А.Д. ПОТЕМКИН 2004. Cephalozia pachycaulis (Hepaticae, Cephaloziaceae) малоизвестный вид для флоры России. - [Cephalozia pachycaulis (Hepaticae, Cephaloziaceae) - a little known species in the flora of Russia] Бот. журн. [Bot. Zhurn.] 89(12): 1890-1897.

KONSTANTINOVA, N.A. \& V.A. BAKALIN 2009. Checklist of liverworts (Marchantiophyta) of Russia. - Arctoa 18: 1-63.

KOŹLIKA, M. 1981. Investigation on variability in the Cephalozia bicuspidata Group. In: Szweykowski, J. New perspectives in bryotaxonomy and bryogeography. Poznac, Adam Mickiewicz University: 1523

LAPSHINA, E.D. \& N.A. KONSTANTINOVA 2012. Hepatics (Marchantiophyta) of the plain of the Khanty-Mansyisk Autonomous District (West Siberia). - Arctoa 21: 85-92.

LINDBERG, S.O. 1872. Spridda anteckningar rörande de skandinaviska mossorna. - Bot. Notis.: 1-16.

LINDBERG, S.O. \& E.FR. LACKSTRÖM 1874. Hepaticae Scandinavicae exsiccata quarum specimina. - Fasc. I. № 1-25. Helsingforsiae. $14 \mathrm{pp}$.

LONG, D.G. \& R. GROLLE 1990. Hepaticae of Bhutan II. - J. Hattori Bot. Lab. 68: 381-440

MÜLLER, K. 1951-1958. Die Lebermoose Europas. - In: Rabenhorst's Kryptogamen Flora von Deutschland, (3-rd ed.) 6: 1365 pp.
PATON, J.A. 1999. The liverwort flora of the British Isles. - Essex, Harley Books. 626 pp.

PIIPPO, S. 1990. Annotated catalogue of Chinese Hepaticae and Anthocerotae. - J. Hattori Bot. Lab. 68: 1-192.

PÓCS, T., E.A. BROWN, A. CAIRNS, D.CH. CARGILL \& S. PÓCS 2012. Contributions to the bryoflora of Australia, III. The genus Nowellia Mitt. (Cephaloziaceae, Jungermanniopsida). - Acta Biologica Plantarum Agriensis 2: 21-26.

[POTEMKIN, А.D.] ПОТЁМКИН А.Д. 1993а. О размножении некоторых печеночников. - [On reproduction of some hepatics] Новости сист. низш. pacm. [Novosti Sist. Nizsh. Rast.] 29: 145-152.

POTEMKIN, A.D. 1993b. The Hepaticae of the Yamal Peninsula, West Siberian Arctic. - Arctoa 2: 57-101.

[POTEMKIN, A.D.] ПОТЁМКИН А.Д. 1995. К флоре печеночников Ленинградской области. Новые и малоизвестные таксоны. 2. - [То the liverwort flora of the Leningrad Region. New and little known taxa. 2] Новости сист. низи. pacm. [Novosti Sist. Nizsh. Rast.] 30: 128-136.

[POTEMKIN, A.D. \& E.V. SOFRONOVA] ПОТЁМКИН А.Д., Е.В. СОФРОНОВА 2009. Печеночники и антоцеротовые России. [Liverworts and hornworts of Russia. 1]. СПб-Якутск, БостонСпектр [St. Petersburg-Yakutsk, Boston-Spektr]: 368 pp.

[SCHLJAKOV, R.N.] ШЛЯКОВ P.Н. 1973. Крупнолистная разновидность Cephalozia leucantha Spruce. - [Macrophyllous variation of Cephalozia leucantha Spruce] Новости сист. низи. раст. [Novosti Sist. Nizsh. Rast.] 10: 302-304.

[SCHLJAKOV, R.N.] ШЛЯКОВ P.Н. 1979. Печеночные мхи Севера CCCP. - [The Hepatics of the North of the USSR] Л., Наука [Leningrad, Nauka] 2: 1-191.

SCHUSTER, R.M. 1974. The Hepaticae and Anthocerotae of North America east of the hundredth meridian. - New York-London: Columbia University Press. 3: $I X+880 \mathrm{pp}$.

SCHUSTER, R.M. 1993. On Cephalozia pachycaulis sp. nov. and the perimeters of Cephalozia. - Bryologist 96(4): 619-625.

SCHUSTER, R.M. 2002. Austral Hepaticae. II. - Nova Nedwigia Beih. 199: $606 \mathrm{pp}$.

STEPHANI, F. 1924. Species Hepaticarum. - Guneve 6: 766 pp.

SZWEYKOWSKI, J. 1984. Species problems and taxonomic methods in bryophytes. - New Manual of Bryology. Nichinan 2: 1130-1171.

VÁŇA, J. 1988. Cephalozia (Dum.) Dum. in Africa, with notes on the genus (Notes on some African Hepatic Genera 10). - Nova Hedwigia Beih. 90: 179-198.

VÁŇA, J. 1993. Taxonomic results of the Bryotrop Expedition to Zaire and Rwanda 11. Cephaloziellaceae, Cephaloziellaceae, Gymnomitriaceae, Jungermanniaceae, Lophoziaceae. - Tropical Bryology 8: 99-103.

VÁŇA, J., L. SÖDERSTRÖM, A. HAGBORG \& M. VON KONRAT 2013. Notes on Early Land Plants Today. 41. New combinations and synonyms in Cephaloziaceae (Marchantiophyta). - Phytotaxa 112(1): 7-15.

VILNET, A.A. N.A. KONSTANTINOVA \& A.V. TROITSKIY 2012. Molecular phylogeny and sytematics of the suborder Cephaloziineae with special attention to the family Cephaloziaceae s.l. (Jungermanniales, Marchntiophyta). - Arctoa 21: 113-132

YAMADA, K. \& Z. IWATSUKI 2006. Catalog of the hepatics of Japan. J. Hattori Bot. Lab. 99: 1-106.

[ZHUKOVA, A.L.] ЖУКОВА А.Л. 1986. Печеночные мхи. - [Liverworts] В кн.: Горные фитоиентические системы Субарктики (ред. Норин, Б.Н.) Л., Наука [In: Norin, B.N. Gornye fitotsenoticheskie sistemy Subarktiki. Leningrad, Nauka]: 292 pp.

[ZHUKOVA, A.L. \& A.D. POTEMKIN] ЖУКОВA А.Л., А.Д. ПОТЁМКИН 1987. К флоре печеночных мхов Ленинградской области. - [To the liverwort flora of the Leningrad Region] Новости сист. низш. раст. [Novosti Sist. Nizsh. Rast.] T. 24. С. 213-217.

[ZINOVJEVA, L.A.] ЗИНОВЬЕВА Л.А. 1973. К флоре печеночных мхов Полярного и Северного Урала. - [To the liverwort flora of the Polar and Northern Urals] Ученые записки Пермского гос. университета [Uchenye Zapiski Permskogo Gos. Universiteta] 263: 14-37. 